Daniel de Menezes Pereira

Aspectos históricos e atuais da perícia médico legal

e suas possibilidades de evolução

Dissertação de Mestrado

Orientadora: Profa. Dra. Irene Batista Muakad

Universidade de São Paulo

São Paulo

2013 
DANIEL DE MENEZES PEREIRA

\section{ASPECTOS HISTÓRICOS E ATUAIS DA PERÍCIA MÉDICO LEGAL E SUAS POSSIBILIDADES DE EVOLUÇÃO}

Dissertação apresentada à banca examinadora da Faculdade de Direito da Universidade de São Paulo, como exigência para obtenção do título de Mestre em Direito, na área de concentração de Direito Penal, Medicina Forense e Criminologia, sob a orientação da Professora Doutora Irene Batista Muakad.

UNIVERSIDADE DE SÃO PAULO

2013 


\section{FOLHA DE APROVAÇÃO}

$\begin{array}{ll}\text { Nome: } & \text { Daniel de Menezes Pereira } \\ \text { Título: } & \text { Aspectos históricos e atuais da perícia médico legal e suas } \\ & \text { possibilidades de evolução } \\ \text { Natureza: } & \text { Dissertação de Mestrado } \\ \text { Objetivo: } & \text { Cumprimento de exigência para obtenção do título de Mestre } \\ \text { Orientadora: } & \text { Professora Doutora Irene Batista Muakad } \\ \text { Concentração: } & \text { Direito Penal, Medicina Forense e Criminologia } \\ \text { Data da Banca: } & \end{array}$

Professora Doutora Irene Batista Muakad (Orientadora)

Professor:

Titulação:

Instituição:

Professor:

Titulação:

Instituição: 


\section{DEDICATÓRIA}

Dedido e tributo (sejam quais forem as acepções de tributar) os frutos deste trabalho:

ao Antonio Pereira Filho, médico, reumatologista, clínico geral, mestre, auditor, conselheiro, perito, revisor, melhor amigo e, nas horas vagas, pai;

à Sandra de Menezes, médica, ginecologista, obstetra, auditora, incansável incentivadora, exemplo de caráter, filha, irmã, tia, madrinha e, acima de tudo, mãe; e

à Larissa Tiemy Ishiwa, gerontóloga, auditora, companheira e, mais importante, aceita conviver com uma pessoa que não chega à sombra de seus progenitores. 


\section{AGRADECIMENTOS}

Agradeço à minha orientadora, Professora Irene Batista Muakad, por ter acreditado no projeto desta dissertação de mestrado desde que ainda era um esboço, bem como por ter me incentivado, e ter oferecido apoio sempre que solicitei.

Agradeço também aos Professores Alamiro Velludo Salvador Netto e Roberto Augusto de Carvalho Campos pelas preciosas observações e conselhos que me foram dados na ocasião da qualificação desta dissertação.

Não podia deixar de mencionar nestes agradecimentos os Professores Antonio Scarance Fernandes, Maurício Zanóide de Moraes, Marcos Alexandre Coelho Zilli e José Raul Gavião de Almeida pela brilhante matéria ministrada ao curso de pós graduação entitulada "Os Meios de Investigação e de Prova, Eficiência e Garantismo", que foi de extrema valia a este estudo.

Outro agradecimento vai ao amigo e Professor Reinaldo Ayer de Oliveira, a quem tive o prazer de ouvir em duas matérias relacionadas à Bioética durante este programa de mestrado, e que ajudou a consolidar minhas bases e convicções sobre o tema.

Agradeço ainda, in memorian, à minha Professora de História Cinília Tadeu Gisondi, que deixou precocemente os amigos, mas não sem antes ter profetizado este momento. Se a outra profecia da mestra estiver também correta, ambas feitas quando eu era ainda um menino, em meu terceiro ano de ensino médio, eu hei de estudar em Coimbra um dia.

Agradeço também aos companheiros contemporâneos de mestrado, em especial dois do mesmo departamento de Direito Penal, Medicina Forense e Criminologia, Bruno Salles Pereira Ribeiro e Luiz Gonzaga Goulart Rodrigues, tanto pela amizade, pelas boas trocas de ideias, quanto pelos valiosos lembretes de prazos e afins.

Cabe aqui também agradecer a primeira pessoa que leu esta dissertação na íntegra, até por ser a única pessoa que a leu capítulo a capítulo, na medida em que eram produzidos. Obrigado, meu pai, Antonio Pereira Filho.

Por fim, agradeço ao Valdir José Maria, "figura carimbada" nas homenagens dos alunos de graduação da Faculdade de Direito da Universidade de São Paulo, e que sempre me disse que a graduação era só o começo.

Muito obrigado a todos! 


\section{RESUMO}

O presente trabalho analisa diferentes aspectos da perícia médico legal, visando buscar formas efetivas de otimizar seus laudos e aferir melhores resultados na busca da verdade dos fatos na Justiça brasileira. Para tanto, é feita uma análise etimológica e uma breve retrospectiva da história da perícia, como forma de melhor entender e contextualizar suas bases e origens. Após, é analisada a realidade brasileira nesta área, em especial no Estado de São Paulo, mediante a verificação da estrutura dos locais de perícia, bem como da qualidade das intervenções dos poderes legislativo e executivo nesta área. É discutida, ainda, a questão da desvinculação da perícia à Segurança Pública no Brasil, bem como é realizado um breve estudo de direito comparado, em que são focadas as diferenças no tratamento legal da perícia entre o ordenamento jurídico brasileiro e os ordenamentos estrangeiros.

Palavras chave: Medicina Legal - perícia médico legal - perícia (processo penal) prova (processo penal).

Título: Aspectos históricos e atuais da perícia médico legal e suas possibilidades de evolução 


\begin{abstract}
This study analyzes several aspects of forensic expertise, aiming to seek effective ways to optimize the expert's reports, consequently benchmarking best results in the search for the truth in investigations carried out in Brazil. Therefore, it was performed an etymological analysis and a brief retrospective of the history of forensic sciences as a way to understand and contextualize its origins and bases. In sequence it was analyzed the Brazilian reality in this field, especially in the State of São Paulo, by means of checking the structure of the locations where the States' official examinations are conducted, as well as the quality of the interventions of the government and the parliament in this field. This work also discusses the issue of untying the States' official examinations from the Citizen Security authorities in Brazil, as well as performs a brief study of comparative Law, which is focused on the differences related to the legal treatment of forensic sciences on foreign Legal systems compared to the Brazilian Legal system.
\end{abstract}

Keywords: Expert examination - Forensic Sciences - Legal Medicine - Expert witness - evidences.

Title: Historical and present aspects of forensic expertise and its possibilities of evolution 
"Deus te guarde do párrafo de legista, o infra de canonista, e etcétera de escrivão, e do récipe de mata-são." (Provérbio popular português)

"Abri a geladeira do IML Cadáver do morro, cadáver eu vi Cadáver sem terra, cadáver barão Cadáver polícia, cadáver ladrão Cadáver turista, cadáver sertão" (Rogério Skylab) 


\section{SUMÁRIO}

I - INTRODUÇÃO

II - Etimologia, CONCEITUAÇão E ABRANGÊnCia dA PERÍCIA

FORENSE

III - A LEGITIMIDADE HISTÓRICA E DESAFIOS DA PERÍCIA MÉDICA NA ATUALIDADE.

IV - BREVE HISTÓRICO E FORMAÇÃO DAS BASES DA PERÍCIA 21

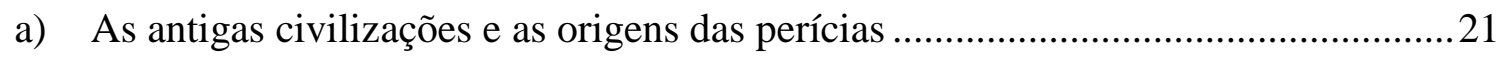

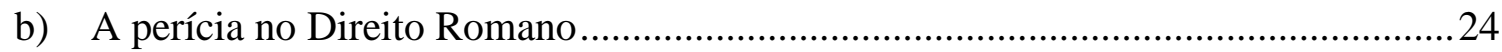

c) As ordálias e a perícia, ou sua ausência, no início da Idade Média.........................27

d) Avanços e retrocessos da perícia na baixa Idade Média e seus reflexos até os dias atuais

e) Os caminhos para o reconhecimento da perícia enquanto ciência na Era pré Moderna 35

f) A perícia no reino de Portugal e as primeiras leis vigentes no "Novo Mundo" .......37

g) A Era das Revoluções, inclusive para a Medicina Legal. 40

h) A perícia médico legal e a Medicina Legal no Brasil 41

V - REALIDADE ATUAL DAS PERÍCIAS MÉdicO LEGAIS NO BRASIL, EM

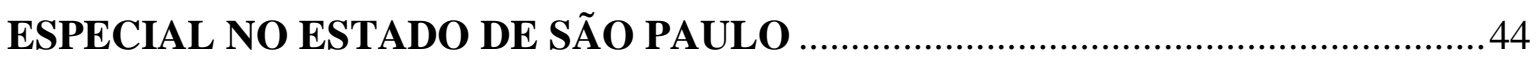

a) Problemas advindos da delegação de responsabilidades ........................................4

b) Organização da Polícia Científica em São Paulo..........................................................46

c) Soluções adotadas para o excesso de demanda e seus riscos ...................................48

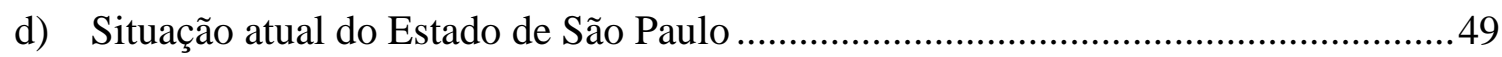

e) Intervenções do Governo estadual e da Assembleia Legislativa ..............................52

VI - A ATUAL VINCULAÇÃo dOS INSTITUTOS MÉdiCO LEGAiS E A

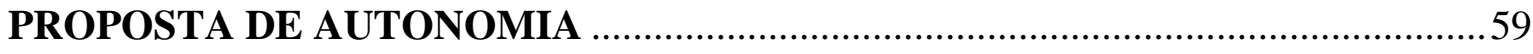


VII - BREVES APONTAMENTOS SOBRE A TEORIA DA PROVA E A PERÍCIA

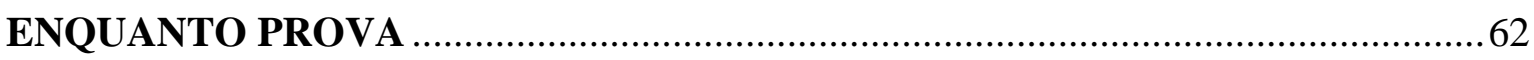

a) Teoria da prova: conceito, objeto, fontes e meios de prova; instrução e

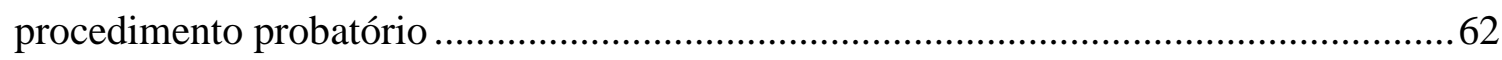

b) A perícia enquanto prova: natureza, procedimento e valoração probatória .............66

\section{VIII -POSSÍVEIS CONTRIBUIÇÕES ADVINDAS DE ORDENAMENTOS JURÍDICOS ESTRANGEIROS À PERÍCIA NO BRASIL ........................................ 72}

a) Possibilidade de aceitação de inovações no ordenamento jurídico brasileiro com relação à prova pericial à luz dos déficits constatados.

b) A perícia em países da Europa Central que influenciaram a cultura e o ordenamento jurídico brasileiro: Portugal, Itália e Espanha. 75

c) A perícia em um ordenamento jurídico totalmente reformulado dentro da América Latina: Chile. 80

d) Os precedentes como forma de discussão acerca da aceitação de provas periciais: Estados Unidos da América

IX - CONCLUSÕES 91 


\section{I - INTRODUÇÃO}

É notório que a Medicina Legal é muito mais uma ciência social do que uma área da Medicina. Afinal, embora tenha seus principais fundamentos trazidos da Medicina e suas respectivas tecnologias, o perito médico legal é um médico que em seu trabalho não se importa diretamente com a vida e com a saúde, mas sim com a evidência. Em outras palavras, o perito não é propriamente um médico no exercício de sua profissão, é um servidor da Justiça e do Direito.

Em algumas vezes, o perito médico legal acaba por exercer o papel de um juiz de fato. Sua importância para a Justiça resulta da assombrosa responsabilidade que lhe é confiada, uma vez que, do resultado do seu trabalho, recorrentemente, dependem questões relacionadas à honra, à liberdade, à psique, entre tantos outros interesses e necessidades que cidadãos buscam através da Justiça. Afinal, sabidamente, em diversas ocasiões o laudo do perito judicial só não constitui uma verdadeira sentença por lhe faltar executoriedade.

Sob diversos aspectos, a importância do perito e da Medicina Legal é inquestionável. Seja no trato direto de questões periciais em processos, seja em ramos do direito que carecem de interpretação médico jurídica, a ausência da contribuição médica e biológica ao Direito acarretaria em um verdadeiro colapso na concepção da boa Justiça, que acabaria por incorrer em erros judiciários infindáveis e incompatíveis com os seus próprios ideais e finalidades.

Afinal, a perícia, tal como hoje é concebida, é fundamental na busca da verdade dos fatos, que constituem, por sua vez, a alma de uma decisão judicial. Se a perícia falhar em trazer a verdade, comprometida restará a sentença; e, ante as partes, em descrédito cairá a Justiça. Ou seja, a credibilidade da Justiça, em especial na esfera criminal, está direta e intrinsecamente relacionada à credibilidade dos seus peritos e na consistência de seus laudos.

A relação entre o Direito e a Medicina, que há tempos tem como seu maior expoente o conceito de Medicina Legal, é antiga. Mais recentemente, a Bioética trouxe à luz o Biodireito, que é um tema muito atual. Todavia, ao longo da história essa relação nem sempre foi harmoniosa. O conceito do ser humano como uma unidade biopsicossocial que hoje se propaga nem sempre existiu. Em vários momentos da história, e ainda nos dias de hoje de forma menos recorrente, ora a Medicina ignorou o 
Direito, ora o contrário.

A Medicina ignorou o Direito, por exemplo, nas experiências realizadas na Alemanha nazista, que inegavelmente colaboraram para o avanço das técnicas da época ao custo de um dos episódios mais repudiantes da história mundial. A Medicina ainda ignora o Direito em casos de eutanásia altruísta (em ordenamentos que não as permitem). O Direito ignorou a Medicina, por exemplo, nos iudicium Dei e suas provas ordálicas. O Direito ainda ignora a Medicina quando considera viva uma pessoa em morte encefálica e em casos de anencefalia.

Os exemplos ao longo da história (por vezes controversos como os propositadamente citados) são muitos. Mas o fato é que, desde a antiguidade, são constatados mais encontros que desencontros. Recorrentemente apenas algumas áreas específicas ou aspectos peculiares das duas ciências ora se juntam, ora se repudiam. Mas, na Medicina Legal, e, particularmente, na perícia, as duas se fundem, de forma que é impossível analisar uma sem ser à luz da outra.

Nesse sentido, o presente estudo busca, em um primeiro momento, analisar como essa fusão surgiu, o que ela resultou, e como seu resultado se transformou e evoluiu, ao fazer uma análise etimológica da perícia e, principalmente, através de um breve, porém sensível, levantamento de suas raízes históricas. Afinal, entende-se no presente estudo que, mais que um prólogo (contrariando William Shakespeare), o passado é a única realidade humana, afinal, tudo o que é já foi (concordando, portanto, com Anatole France).

$\mathrm{Na}$ sequência, buscará o presente estudo analisar a realidade da perícia nos dias atuais, tanto no contexto local, como em esfera global. Tal abordagem se mostrou relevante, uma vez que, se a Medicina ao redor do mundo parece confluir no conceito de Medicina baseada em evidências, o Direito, ao contrário, ainda demonstra ter diversos pontos divergentes entre os ordenamentos jurídicos das diversas nações, em pleno Século XXI.

A partir de observações prévias acerca da qualidade, do aproveitamento, da relevância e dos rumos das perícias no ordenamento jurídico brasileiro, será uma constante nesse estudo a busca da evolução da perícia, tal como hoje é concebida. Em toda a discussão do tema, se buscará identificar problemas e apontar possíveis soluções para a otimização da qualidade e utilidade dos laudos periciais, almejando essa ser uma forma de contribuir com a busca da verdade dos fatos e, portanto, com a Justiça como um todo. 
Para tanto, além dessa introdução e das conclusões ao final apresentadas, esse estudo foi dividido em outros sete capítulos. Adiante serão descritas, brevemente, suas pretensões e justificativas.

O segundo capítulo desse estudo, que se encontra logo após esta introdução, aborda a etimologia, a conceituação e a abrangência do termo "perícia forense". Tal capítulo foi incluído como forma de limitação do presente estudo, bem como início de investigação das raízes históricas do tema.

O capítulo seguinte discorre sobre a legitimidade histórica da perícia enquanto prova (ou seu meio), bem como os desafios da boa utilização da perícia na atualidade. Em complemento ao capítulo anterior, esse introduz o tom crítico que pretende se desenvolver ao longo da discussão e apresenta parte da problemática que se pretende abordar.

O quarto capítulo, por sua vez, é um dos mais extensos e, provavelmente, o mais pretensioso do presente estudo. Buscou o capítulo traçar um breve histórico da perícia, em especial no mundo ocidental, bem como analisar a formação das bases da perícia na atualidade. Seu objetivo é o de detectar as origens dos vícios, bem como entender as virtudes que permearam a prática ao longo dos anos, de forma que se possa aproveitar o melhor que a história tem a ensinar.

Contrastando com a natureza de narrativa histórica e crítica do capítulo anterior, o capítulo seguinte traz dados sobre a realidade atual das perícias médico legais no Brasil. Com enfoque no Estado de São Paulo, que por si representa uma boa amostra do que é feito no resto do país, abordou-se as estruturas das unidades periciais, bem como os trabalhos e esforços dos poderes executivo e legislativo sobre o tema. Com algumas estatísticas e análises de projetos de lei, tal capítulo é fundamental para entender as formas como os avanços podem ser regulamentados e implementados.

Por sua vez, o sexto capítulo, um dos menos extensos, traz à tona um assunto que não é novidade, porém há tempos é postergado, abordando a atual vinculação dos Institutos Médico Legais, que, em regra, é às Secretarias de Segurança Pública dos Estados. Dentre seus objetivos está a análise dos benefícios que poderiam advir da proposta que visa dar autonomia aos órgãos periciais.

Já o sétimo capítulo do presente estudo dá embasamento teórico às asserções dos capítulos anteriores, bem como às conclusões a que se pretende chegar, ao oferecer uma visão geral sobre a teoria da prova, bem como a perícia enquanto prova no ordenamento jurídico brasileiro. Tal análise é considerada de extrema importância para a compreensão 
do tratamento dado à perícia pelos ordenamentos jurídicos estrangeiros, bem como para a compreensão dos institutos que eventualmente podem ser emprestados destes ao Direito Brasileiro.

O oitavo capítulo, que é também o último capítulo de discussão do presente estudo, dá desfecho ao primeiro, ao traçar um panorama geral do tratamento jurídico dado por alguns ordenamentos jurídicos distintos à perícia na atualidade. Esse breve estudo de Direito comparado tem por objetivo permitir identificar como as diferentes origens de cada ordenamento, em parte abordadas nos apontamentos históricos, se traduziram em diferenças no reconhecimento da perícia pelo Direito em diferentes sistemas legais.

Ao final, seguirão breves conclusões, que destacarão os argumentos e constatações do presente estudo que, em tese, podem contribuir com a evolução e otimização da prática da perícia médico legal no ordenamento jurídico brasileiro. Finda a introdução, seguem adiante os apontamentos, as pesquisas, referências e discussões acerca do presente tema. 


\section{II - ETIMOLOGIA, CONCEITUAÇÃO E ABRANGÊNCIA DA PERÍCIA FORENSE}

De acordo com a etimologia sugerida pelo Dicionário Houaiss ${ }^{1}$, o termo Perícia vem do Latim periťa (ae), que corresponde a conhecimento adquirido pelo uso, pela experiência, que, por sua vez, é derivado de perītus $(a, u m)$, que seria aquele que sabe por experiência, ou seja, o próprio perito, ou experto, que, com seu conhecimento, dá origem à perícia na acepção que conhecemos.

O Dicionário Latino-Português, de José Cretella Junior e Geraldo Ulhoa Cintra ${ }^{2}$ define a perícia com o mesmo sentido. Indica que o termo Latim perita (ae) dá origem à perícia, que define uma ciência experimental, perfeito conhecimento, capacidade e inteligência. Segundo o mesmo dicionário, o termo forensis, também advindo do Latim, dá origem ao que conhecemos por forense, que indica tudo aquilo que é pertencente ao foro judicial. Assim, a perícia forense é aquela realizada pelo peritus $(a, u m)$, palavra que indica o perito, o douto, o sábio, o experimentado, o inteligente.

Definidos o conceito e a etimologia da perícia forense, a conceituação da prova pericial, sob aspecto objetivo, sucintamente, consiste no meio pelo qual a verdade chega ao íntimo ou ao espírito de quem a aprecia, como se fosse uma forma de demonstração da verdade dos fatos atinentes à lide.

Quanto ao aspecto subjetivo a prova pericial, em uma pálida concepção, é a própria convicção da verdade dos fatos alegados, sendo resultado do exame imparcial e técnico da prova, ou seja, o atestado de uma condição, retida aos fatos apresentados.

Dessa forma, é possível compreender a perícia como sendo uma pesquisa que exige conhecimentos técnicos, científicos ou artísticos. Entretanto, ela pode ser considerada um meio de prova, um testemunho de um experto (em especial por meio da figura do expert witness, consagrado, não apenas, mas, peculiarmente, no Direito Norteamericano, e que será abordada adiante), bem como pode ser entendida como uma prova em si, já que possui tudo que se exige de um meio de prova e mais um conhecimento que na prova em si não existe; sendo assim mais que um sujeito de prova, e menos que um juiz.

1 HOUAISS, Antonio. Grande Dicionário Houaiss da Língua Portuguesa. Disponível em 〈http://houaiss.uol.com.br>. Acesso em: 23 dez. 2012.

${ }^{2}$ CRETELLA JR. José; CINTRA, Geraldo de Ulhoa (Orgs.). Dicionário Latino-Português, $3^{\mathrm{a}}$ ed., São Paulo, Companhia Editora Nacional, 1953. 
Neste sentido, se o perito se limitasse a transmitir ao juiz o apurado com seus conhecimentos técnicos, a perícia seria apenas meio de prova, ou um testemunho, conforme anteriormente mencionado. Porém, a partir do momento em que o perito emite juízo de valor sobre os fatos, externando sua impressão sobre a possibilidade de terem os fatos sido originados por outros acontecimentos ou autores, e eventualmente de virem a produzir ainda outros efeitos, ele acaba por considerar não só a realidade dos fatos, estática e imutável, mas passa também a trabalhar com probabilidades, baseadas nos princípios do experto, adquiridos por meio de sua experiência.

Essa ideia possibilita afirmar que o perito não se restringe apenas a trazer meros relatos ao juiz acerca dos fatos e dos materiais, pessoas ou quaisquer outros objetos a que tenha tido acesso, baseados em sua experiência científica ou artística, posto que muitas vezes o juiz, previamente informado dos fatos ocorridos, requer informações quanto às consequências dos fatos ou ações e, muitas vezes, inclusive, qual o seu valor. Isso permite concluir que o diagnóstico, o prognóstico e a própria opinião do perito não podem ser considerados meros meio de prova, mas sim um conceito mais abrangente, que torna a perícia, por vezes, a mais legítima das provas, conforme se discutirá adiante.

Obviamente, em muitos casos, pode o perito nem se pronunciar quanto ao fato, e apenas oferecer ao juiz esclarecimentos teóricos e gerais que lhe permitam suficiência para julgar. Nesse sentido, basta ser possibilitado estabelecer de maneira segura o nexo de causalidade entre os fatos e autores, em especial, o ato ou a omissão pelos quais se pauta a lide, o bastante para o convencimento do julgador, por processos científicos, que a perícia forense, ou a opinião do perito, terá exercido seu papel. Mas, ainda assim, isso ocorre pelo fato de que a matéria da lide em questão versa sobre fatos em que os finais examinadores, de forma correlata aos julgadores propriamente ditos, são justamente os peritos, cabendo ao juiz, por vezes, apenas o papel de ratificador daquela opinião, que, por vezes, passa a ter o valor de decisão, de forma final e completa. 


\section{III - A LEGITIMIDADE HISTÓRICA E DESAFIOS DA PERÍCIA MÉDICA NA ATUALIDADE}

Desde as antigas civilizações e nas mais primitivas Eras documentadas na história, conforme se abordará adiante, são recorrentes as constatações de que a Medicina e o Direito tentam encontrar denominadores comuns para, mútua e proficuamente, colaborarem entre si. Afinal, entre os pilares da sociedade moderna, verifica-se a consagração de dogmas milenares que até hoje convergem neste ímpeto; tanto por questões sociais, pessoais (nem sempre éticas), religiosas, políticas, entre outras. Mas, cada vez mais e, principalmente, por questões éticas, além das religiosas, instaurou-se o enorme desafio de juntar, de forma satisfatória, essas artes cada vez mais interligadas.

Dos muitos desdobramentos desse tema, que tem sido objeto de estudos recorrentes, em escala global, são relevantes as discussões que permeiam a perícia médico legal, assunto de extrema importância para a consolidação de diretrizes que tentam amenizar diversos conflitos técnicos e, também, irrefutavelmente éticos.

Surge, então, a necessidade de constantemente serem atualizadas as posições dos peritos e das técnicas em si, tanto historicamente, quanto social e economicamente, no intuito de se traçar uma fotografia que permita apontar erros e buscar melhores resultados diante da relevante quantidade de críticas que, recorrentemente, são apontadas em perícias desse tipo.

Nesse sentido, um dos principais motivos deste estudo foi justamente o acompanhamento de trabalhos de peritos médicos, fossem eles nomeados pelo juiz ou atuantes como assistentes técnicos de partes, o que levou à constatação de que, nos dias atuais, e, principalmente, na realidade brasileira, por diversas vezes, o cerne da discussão processual volta-se a imprecisões constatadas no laudo realizado pela perícia.

No âmbito processual, por exemplo, a utilização de expressões imprecisas ou ambíguas, tais como "grande quantidade", "relevante prejuízo", "dano considerável", "visível alteração", entre outras, por vezes mostrou-se fundamental para que a defesa ou acusação (frequentemente em sede de recurso) se valesse de tal imprecisão para desviar a questão do foco principal. Pior, tais imprecisões, por diversas vezes, acabam por desfavorecer inclusive o mérito e a satisfação das partes, em especial, quando utilizadas indevidamente como medidas protelatórias.

Para exemplificar, uma "grande quantidade" de fluído dentro de um órgão, durante 
uma autópsia, é algo que sugere poucos indícios sobre a causa mortis. Já uma "grande quantidade de sangue", por sua vez, pode sugerir uma provável causa mortis. Mas apenas sugerir. Ao contrário, se tivesse sido feita a valoração precisa da quantidade, a causa mortis poderia ser definida, e não sugerida.

O exemplo acima poderia facilmente solucionar um caso de suposto erro médico, um agravante ou atenuante de pena, ou uma distinção entre dolo e culpa. Mas, ao invés disso, a imprecisão, facilmente corrigível no momento da autópsia, frequentemente tem pouco ou nenhum valor na decisão do magistrado, ou até mesmo do perito por ele nomeado, por conter tal imprecisão.

Obviamente, o caso acima suposto é um exemplo específico, de apenas uma das imprecisões ou falta de padronizações de procedimentos, que se percebem em laudos periciais atualmente. Mas sua utilização serve de exemplo para justificar a necessidade do conhecimento pelos médicos legistas, sobre as circunstâncias já sabidas e conhecidas do caso, o que, na prática, dificilmente ocorre.

Como agravante dessa situação, na prática, percebe-se que quando se fala em causa mortis, dificilmente se tem casos discutíveis quando as causas são comuns. Afinal, um infarto do miocárdio não é nada parecido com um traumatismo craniano, que, por sua vez, em nada se parece com a evolução de um carcinoma em fase terminal.

Porém, entre essas causas mortis bem definidas, há uma série de outras em que o motivo não é totalmente perceptível, mas apenas sugestivo. Nesses casos, fundamental seria uma autópsia completa e precisa, e não apenas uma verificação de óbito, sugerindo uma causa que, por meio de exame rigoroso, poderia ser plenamente constatada ou rechaçada.

Cabe ressaltar, novamente, que este trabalho não questiona, em hipótese alguma, a competência dos médicos legistas. Ocorre que, por vezes, eles não têm a orientação, aparato, condições técnicas, ou informações que lhes permitam, por meio do laudo ou atestado, contribuir efetivamente para uma investigação, ou para a conclusão do colega perito futuramente nomeado pelo juiz, ou ainda um auxiliar técnico das partes, conforme previsto nos códigos de processo pátrios.

Nesse viés, o presente estudo visa investigar muito mais os laudos sobre cadáveres do que sobre vivos. Não apenas por conta do visum et repertum constatados nas perícias específicas feitas em pessoas vivas, mas também por que elas são capazes de descrever a agressão ou o dano e informar o perito sobre o que deve ser observado, o que não acontece com os cadáveres, por óbvio. 
É nesse contexto que o presente estudo tem como um de seus objetivos fomentar melhorias na forma de elaboração de laudos, provas legítimas e preciosas, conforme já mencionado, e que por vezes são ofuscados ou anulados por vícios e imprecisões evitáveis.

Os vícios constatados em laudos periciais podem ser decorrentes de falta da comunicação eficiente, de falta de condições mínimas para a realização de uma perícia adequada, ou, até mesmo, de deficiência de pessoal (seja numérica, seja técnica). Busca este projeto apontar as virtudes e deficiências das instituições criminalísticas e periciais, com o intuito de que os laudos por elas elaborados deixem de ser objeto de discussões processuais infrutíferas, e passem a valer como provas incontestáveis; cumprindo assim seu derradeiro papel na política criminal, na justiça processual, na própria satisfação dos profissionais que atuam nessas áreas, ou até mesmo na correta adoção de políticas de saúde pública, que utilizam a base de dados deflagrada pelos laudos como principal delineadora de suas ações.

Apenas para citar um segundo efeito maléfico dos laudos inconclusivos, o Programa de Aprimoramento das Informações de Mortalidade ("Pro-Aim") ${ }^{3}$., criado pela prefeitura da Cidade de São Paulo, em 1989, atualmente é subutilizado por falta de dados conclusivos. Fossem os laudos mais padronizados, efetuados com equipamentos adequados, além de profissionais e auxiliares treinados, a sociedade poderia se valer dos inúmeros benefícios de uma base de dados como esta pode oferecer.

Novamente, cabe citar que o presente estudo não tem por objeto sequer dar uma pálida fotografia da situação atual dos Institutos Médico Legais, o que tem sido, vez ou outra, foco da imprensa, que em diversas ocasiões apontou que tais locais possuem instalações precárias, cheiro podre e falta de técnicos (conforme relatos recentes do jornal Folha de São Paulo) ${ }^{4}$. Entretanto, não pôde esta pesquisa se furtar a investigar os motivos de tal situação, vez que é uma das origens da principal problemática em questão, o que será feito adiante, em capítulo próprio, com base em dados oficiais e outras informações investigadas a esse respeito.

Tampouco pretende este estudo fazer uma densa e aprofundada investigação da

3 PREFEITURA DA CIDADE DE SÃO PAULO. Programa de Aprimoramento das Informações de Mortalidade. 1989 a 2013. Conteúdo disponível em <http://www.prefeitura.sp.gov.br/cidade/secretarias/saude/epidemiologia_e informacao/mortalidade/>. Acessado em: 02 jan. 2013.

${ }^{4}$ FOLHA DA MANHÃ S.A.. IMLs de SP têm instalações precárias, cheiro podre e falta de técnicos. 2013. Disponível em <http://www1.folha.uol.com.br/cotidiano/1210727-imls-de-sp-tem-instalacoes-precariascheiro-podre-e-falta-de-tecnicos.shtml >. Acessado em 06 jan. 2013. 
história da perícia médica, em especial a forense, desde a antiguidade. Entretanto, uma vez mencionados os conflitos entre Direito e Medicina neste apontamento, coube a inclusão de um capítulo sobre a evolução histórica da perícia, até que para adiante se pudesse debater práticas de aceitação da perícia enquanto provas em ordenamentos jurídicos estrangeiros, que diferem consideravelmente das práticas atualmente adotadas no Brasil. 


\section{IV - BREVE HISTÓRICO E FORMAÇÃO DAS BASES DA PERÍCIA}

Embora o objeto principal do presente estudo seja a perícia médica no âmbito forense, a investigação das origens da perícia tal como conhecemos é de extrema importância para a compreensão de suas implicações legais e práticas, bem como a análise dos princípios éticos e morais que a permeiam. Esta abordagem se mostra de extrema relevância, vez que é possível confrontar as raízes históricas da perícia com a realidade atual, estabelecendo paralelos e, possivelmente, fazendo justiça às origens dos instrumentos jurídicos e filosóficos que embasam a perícia forense tal como hoje é concebida.

Nesse sentido, o presente estudo não focará apenas na era científica da Medicina Legal, que comumente é reconhecida como iniciada na França, com Ambroise Paré ${ }^{5}$, que compilou, em 1575, seus estudos sob o título "Les Oeuvres de M. Ambroise Paré, avec les figures et les portraits de l'Anatomie que des instruments de chirurgie et de plusieurs monstres" (em tradução livre seria "A obra do Dr. Ambroise Paré, com figuras e retratos de Anatomia, como instrumentos cirúrgicos e demais monstros”). Ambroise Paré, por muitos, é considerado o "pai" da Medicina Legal. De fato, Paré foi de extrema importância no âmbito da anatomia, como cirurgião que era, bem como na descrição técnica de acidentes trágicos, sendo atribuído a ele a expressão "a arte de fazer relatórios em juízo" como o trabalho do perito médico em âmbito forense.

Entretanto, a perícia tal qual conhecemos e seus desdobramentos tiveram início milhares de anos antes, conforme melhor se descreverá adiante, tendo como delimitação o enfoque na perícia no mundo ocidental.

\section{a) As antigas civilizações e as origens das perícias}

Os registros das análises de corpos de cadáveres de forma muito próxima à realizada até os dias atuais remonta aos primeiros séculos de nosso calendário, sendo um dos mais antigos registros datado do Século II, conforme análises do papiro Abbott, compiladas por Rodolphe Dareste de la Chavanne ${ }^{6}$, em sua obra Études d'histoire $d u$

\footnotetext{
${ }^{5}$ BITTAR, Neusa. Medicina Legal. $1^{\text {a }}$ ed., Araçatuba, Editora MB, 2009, p.13.

${ }^{6}$ DARESTE, Rodolphe. $10^{\mathrm{a}}$ ed., Paris, L. Larose et. L Tenin, 1908, pp. 02-06. Cópia integral disponível em <http://ia600306.us.archive.org/23/items/tudesdhistoired00chavgoog/tudesdhistoired00chavgoog.pdf >

Acessado em 28 dez. 2012.
} 
Droit (em tradução livre "Estudos da História do Direito"). As peças analisadas por Dareste descrevem relatórios supostamente médicos sobre ferimentos sofridos por um indivíduo. Mas o que mais impressiona nesses relatos é que os documentos possuem características de formalidade, requisição e endereçamento às autoridades, relatos de testemunhas, descrição minuciosa do averiguado, incluindo supostos agentes causadores das lesões, e registro do recebimento do documento pela autoridade.

Dessa forma, diante de todas essas características de formalidade, de precisão e de descrição apurada, é possível concluir que pelo menos há dois mil anos as perícias médicas para fins legais e investigatórios são realizadas, ainda que não necessariamente forenses na acepção que hoje conhecemos. Essa constatação faz com que todas as demais codificações e registros históricos que tratam da perícia forense mereçam atenção no presente estudo, e que datam de períodos consideravelmente anteriores à Medicina Legal (que, enquanto disciplina jurídica, só foi oficializada no Século XVIII, nas escolas francesa, alemã e italiana ${ }^{7}$ ).

A mais antiga codificação penal que se tem registro, que é o Código de Hamurábi, também merece ser citado, uma vez que também é o primeiro documento legal que abordou o erro médico. Esse códex previa, inclusive, punições em Artigos 218 a $220^{8}$ para casos de imperícia de médicos (Mesopotâmia, Século XVIII a.C.).

Também merece destaque, no campo da Medicina Legal, o Código de Manu, que vigorou na Índia no Século V. a.C. Este proibia que, além de crianças e velhos, pessoas com distúrbios mentais fossem ouvidas como testemunhas, o que pressupõe a existência de alguém que constatasse tal estado, o que, por sua vez, indica a realização de uma espécie de perícia a esse respeito ${ }^{9}$.

Como se pode perceber, desde muito antes da Roma Antiga até ao Código Criminal Carolino (Século XVI), existem importantes apontamentos e registros históricos que auxiliam na compreensão dos parâmetros éticos do exercício da perícia e até mesmo suas questões técnicas. Cita-se, nesse item, o Código Criminal Carolino, pois foi nele que, pela primeira vez, passou a ser exigido, de forma sistemática, pareceres de médicos e parteiras para esclarecimento dos julgadores nos casos de lesões corporais,

\footnotetext{
${ }^{7}$ BITTAR, Neusa. op. cit., p.14.

8 JOHNS, Claude Hermann Walters (Org.). Enyclopaedia Britanica. $11^{\mathrm{a}}$ ed. Londres, Enyclopaedia Britanica, Inc., 1901. Versão em português do excerto disponível em 〈http://www.faimi.edu.br/v8/RevistaJuridica/Edicao6/c\%C3\%B3digo\%20de\%20hamurabi.pdf〉. Acessado em 28. Dez. 2012.

${ }^{9}$ HÉRCULES, Hygino de C. Medicina Legal: Texto e Atlas. São Paulo, Atheneu, 2005, p. 5.
} 
homicídios, infanticídios, partos clandestinos, abortamento, entre outros ${ }^{10}$.

No mundo ocidental, onde se passou-se a aplicar posteriormente o Direito Romano, os primeiros registros de intervenção da figura do médico como perito datam dos Séculos XIV e XV, quando foram registradas perícias médico legais, ainda que rudimentares ${ }^{11}$. Até então, não era exatamente a figura atual do perito que fazia a análise e a coleta de provas, era normalmente realizada pelo próprio julgador, que analisava as controvérsias como um árbitro escolhido pelas partes, e que realizava a verificação dos fatos diretamente, indo pessoalmente aos locais e examinando as provas ${ }^{12}$. Dessa forma, é possível afirmar que o exame judicial é predecessor da perícia, estando as funções de juiz e perito diretamente relacionadas em suas origens.

A constatação da interligação entre o julgador e o perito, por vezes concentrados na mesma pessoa, inclusive, aparecem nos apontamentos de Dareste em outros ordenamentos antigos, como no antigo Direito Eslavo e nos primórdios do Direito Húngaro e Germânico ${ }^{13}$. Outros apontamentos semelhantes são encontrados em tempos ainda mais remotos, como na antiga civilização egípcia, em que lotes repassados a súditos contra a obrigação de pagamento de tributos eram referenciados por marcos e sinais $^{14}$, e nas ocasiões em que o rio subtraía parte da área, o lesado informava as autoridades, que enviavam súditos capacitados em geometria, que eram especialistas na arte de medição, para determinar, a seus critérios, a remarcação.

Também menciona Dareste ${ }^{15}$ e Moacyr Amaral Santos ${ }^{16}$ que os hebreus (ou israelitas, conforme utilizado por Dareste, mesmo décadas antes da criação do Estado de Israel) possuíam sistema de distribuição de terra semelhante, sendo considerado delito grave a invasão de terras. Por este motivo existiam expertos em mensuração de terras que atuavam em casos de partilha ou negociação delas.

$\mathrm{Na}$ esfera criminal, em eventos que resultavam em morte, possuíam os hebreus um instituto assemelhado a uma verificação de óbito com detecção causa mortis, que era realizado por juízes e anciãos, diretamente no local dos fatos. A sentença determinava a

${ }^{10}$ BRASIL, Conselho Federal de Medicina - CFM. Pareceres. Protocolo 44.482. Brasília, 1995. Excerto disponível em < http://www.portalmedico.org.br/pareceres/crmba/pareceres/1995/3 1995.htm>. Acessado em 15. Dez. 2012.

${ }^{11}$ BRASIL, Conselho Federal de Medicina - CFM. op. cit. Acessado em 15. Dez. 2012.

12 SILVA, Alexandre Alberto Gonçalves. A perícia forense no Brasil.São Paulo, Escola Politécnica da Universidade de São Paulo, 2010, pg. 15.

${ }^{13}$ DARESTE, Rodolphe. op. cit., pp. 240, 277 e 404.

${ }^{14}$ SILVA, Alexandre Alberto Gonçalves. op. cit., p. 16.

${ }^{15}$ DARESTE, Rodolphe. op. cit, p. 20.

${ }^{16}$ SANTOS, Moacyr Amaral. Prova Judiciária no cível e comercial, vol. 1, $5^{\mathrm{a}}$ ed. atual., vol. 1, São Paulo, Saraiva, 1983. 
causa mortis e, sendo constatado um homicídio, o parente mais próximo do morto era obrigado a acusar o homicida ${ }^{17}$, instaurando, assim, uma espécie de processo, que era conduzido pelo julgador e que, posteriormente, poderia culminar em pena de morte.

Sistema ligeiramente mais complexo era encontrado na antiga Grécia ${ }^{18}$. Em Atenas, por exemplo, casos de delitos mais graves eram denunciados à Assembleia do Povo ou ao Senado, os quais indicavam o acusador para composição de tribunal popular. Ele era o responsável pela produção de provas, e os juízes apenas garantiam que o embate entre as partes seria leal, já que a definição quanto à condenação era por voto popular. O prazo entre a convocação e o dia do julgamento não deveria exceder um mês, e era afixada no pretório uma exposição do acusador para que pudessem eventualmente surgir novas provas para confirmar, ou desconstruir, a acusação.

É possível afirmar, portanto, que o processo penal na Grécia antiga tinha por característica a participação direta dos cidadãos no exercício da acusação, e que eram marcantes a publicidade e oralidade do processo, sendo o juiz um sujeito imparcial, sem ingerência direta nos debates e nas provas, distante da confusão entre juiz e perito verificada em outros sistemas.

\section{b) A perícia no Direito Romano}

Retomando as características do Direito Romano, preliminarmente, é possível destacar, de forma sucinta, que o processo romano pode ser divido em três principais períodos ${ }^{19}$, notadamente o legis actiones (de forma livre, traduzido por o período das ações da lei), o per formulas (em livre tradução, o período formulário), e o cognitio extraordinaria (traduzido livremente por processo extraordinário).

Este estudo não tem qualquer ambição de definir ou delimitar tais períodos, destacando apenas que referidos sistemas coexistiram e vigoraram como evoluções um do outro sucessivamente. O que realmente importa para a questão da evolução histórica da perícia forense é que uma constante tendência do Direito Penal Romano foi de tornar de interesse público praticamente toda a ação penal, sendo o Direito penal privado restrito a poucos tipos penais personalíssimos.

\footnotetext{
${ }^{17}$ ALMEIDA JUNIOR, João Mendes de. O Processo Criminal Brazileiro, vol. 1, $3^{\mathrm{a}}$ ed., Rio de Janeiro, Livraria Freitas Bastos S.A., 1959.

18 LAGO, Cristiano Alves Valladares. Sistemas Processuais Penais. Disponível em <http://www.viannajr.edu.br/revista/dir/doc/art 30005.pdf >, p. 05. Acessado em 15. Dez. 2012.

${ }^{19}$ TUCCI, José Rogério Cruz et, AZEVEDO, Luiz Carlos de. Lições de História do Processo Civil Romano, São Paulo, Revista dos Tribunais, 2001.
} 
Dessa forma, o processo era conduzido em nome do Estado Romano, figurando o julgador (neste caso já próximo à figura do magistrado) como representante do Estado s(inicialmente do Rei, posteriormente do Imperador). A ele, portanto, eram outorgados amplos poderes de iniciativa, instrução e deliberação, sem requisição de maiores formalidades (o que incluía por vezes até mesmo o julgamento na ausência das partes), consagrando, então, o processo denominado cognitio, no qual o magistrado, mediante a mera apresentação da notitia criminis, passava a, de ofício, investigar a denúncia ${ }^{20}$.

É notório que a utilização da perícia como meio de prova no processo romano restou consagrada após a revolução que derrubou a monarquia e instaurou a república em Roma, trazendo consigo uma série de reformas sociais, incluindo o aparecimento da Lei das Doze Tábuas, resultado de um estado de coisas mentais e públicas completamente novo $^{21}$. A Lei das Doze Tábuas não é a primeira compilação de leis que se tem registro em Roma, mas sim uma decodificação de clamor popular, que reflete as inexperiências de um povo que nunca tinha feito um código, e que ainda assim conseguiu trazer avanços ao processo penal, nem que de forma mais teórica que prática.

Embora, em referido códex, os tipos penais ainda refletissem a sobrevivência de costumes e heranças culturais bárbaras, era uma lei preocupada principalmente com o processo judiciário, com o direito privado e com os delitos ${ }^{22}$. E, nesse ímpeto, passou a reconhecer a prova pericial, ainda que de forma implícita, no Direito Romano.

Neste sentido, passou a ser reconhecida a figura do iudex, que embora não fosse um perito ou juiz propriamente dito, era um particular, não representante do Estado, que tinha poder de decidir determinadas causas. Atuando como um árbitro, o iudex era um cidadão romano eleito pelas partes, ou sorteado por um magistrado em caso de discordância das partes.

No momento de produção de provas, o in iudicio, o iudex atuava como verificador quando se tratava de casos de exame, de maneira soberana, não subordinado hierarquicamente após a nomeação. Esse exame em outros ordenamentos, na maioria das vezes, constituía um ato exclusivo e pessoal do juiz, sendo essa figura uma inovação importante do Direito Romano rumo ao que hoje se conhece por perícia.

Ainda que os registros apontem para perícias nesse período majoritariamente na esfera civil, e em casos que as partes buscavam maior imparcialidade em questões que

\footnotetext{
${ }^{20}$ LAGO, Cristiano Alves Valladares. op. cit., p. 06.

${ }^{21}$ SALDANHA, Nelson Nogueira. A Lei das doze tábuas e o direito penal romano. Revista Symposium, Recife, v. 3, n. 1/2, 1961, p. 70

${ }^{22}$ SALDANHA, Nelson Nogueira. op. cit. p. 73.
} 
demandavam conhecimentos específicos, esse foi um primeiro passo para o posterior reconhecimento da figura do perito. Tal reconhecimento viria mais tardiamente no processo penal. Nesse sentido, Almeida Júnior ${ }^{23}$ afirma que à época, após o ato da acusação, que poderia ser realizada por qualquer pessoa capaz, o acusador solicitava a formalização da acusação ao pretor, que verificava se o fato constituía crime. Em caso positivo, este ainda por seu próprio convencimento e discernimento, rejeitava ou admitia a ação, independente de qualquer expertise própria ou de terceiros, cabendo exclusivamente ao acusado fiscalizar a produção de provas do processo, sem ter o direito de delegar a função a terceiros, ao menos de forma oficial.

É fato que o acusado tinha o direito de seguir o acusador e, acompanhado de um agente indicado pelo juízo, seguir até mesmo a oitiva de testemunhas ${ }^{24}$. $\mathrm{O}$ acusador, por sua vez, poderia ter o auxílio de uma comissão a ser nomeada pelo pretor, podendo realizar investigações, apreender documentos, notificar e inquirir, entre outros meios de investigações correlatos. Mas, em nenhum momento, qualquer desses atores se aproximavam da figura de um perito (tal como hoje se concebe).

Entretanto, em casos extraordinários, após a fase preparatória do processo, o julgador poderia pedir esclarecimentos a pessoas qualificadas para decidir sobre algumas questões técnicas apresentadas. Por exemplo, existia a previsão legal da atuação de parteiras em casos de gravidez de mulher divorciada, além de em questões de terra solicitar o laudo de agrimensores em casos de marcos apagados por ocorrências da natureza ${ }^{25}$. Mas, novamente, esses agentes com expertise exerciam a função de árbitros, e não exatamente de peritos.

Eis que com a queda do Império Romano do Ocidente (datada historicamente de 476 d.C., com a deposição do último imperador romano, Rômulo Augusto ${ }^{26}$ ) e a invasão dos godos, suevos, alanos, vândalos, entre outros povos, grande parte da atual Europa ocidental (e que culmina com a gênese do período conhecido por Idade Média), aos poucos, os procedimentos processuais predominantes nas civilizações dominadas pela influência do Império Romano cedeu lugar ao processo acusatório germânico, permanecendo, no entanto, grandes influências do Direito Romano, com absorção mútua

\footnotetext{
${ }^{23}$ ALMEIDA JUNIOR, João Mendes de. op. cit.

${ }^{24}$ SILVA, Alexandre Alberto Gonçalves. op. cit., p. 21.

${ }^{25}$ SANTOS, Moacyr Amaral. op. cit.

${ }^{26}$ GIBBON, Edward; SAUDERS, Dero A. (Org,); PAES, José Paulo (Trad.). Declínio e queda do Império Romano. Ed. abr. São Paulo, Companhia da Letras, 2005.
} 
de institutos adotados pelos diferentes sistemas jurídicos ${ }^{27}$.

\section{c) As ordálias e a perícia, ou sua ausência, no início da Idade Média}

Nos novos ordenamentos, em regra, a justiça passou a ser administrada por uma Assembleia, que normalmente era presidida por um membro da realeza. No que tange às regras processuais do período, o ônus da prova, quase invariavelmente, recaía sobre o réu, que devia demonstrar cabalmente sua inocência, sob a pena de ser condenado.

Em pálida descrição, até pela nebulosidade dos julgamentos da época, as principais fontes de provas eram os institutos conhecidos como as ordálias (ou ainda "ordálios", que, ao que se tem conhecimento, têm origem no Direito Persa ${ }^{28}$, mas também fizeram parte, e estão relatadas, nos ordenamentos da Roma e Grécia antigas), e os iudicium Dei (em tradução livre, “juízos de Deus”).

Sem fundamentação teórica (muito menos científica), nas ordálias, o réu jurava sua inocência, enquanto se acreditava que um deus, conhecedor do passado do acusado, pudesse castigar o réu que jurava falsamente.

Por sua vez, os iudicium Dei não eram uma fonte de prova, tal como hoje se conhece. Embora, em tese, constituíssem a "devolução a Deus" de sua a capacidade de julgamento da culpabilidade ou inocência do acusado, eram verdadeiros rituais de tortura, onde o réu dificilmente tinha a oportunidade de se salvar da condenação.

Em regra, os iudicium Dei constituíam afamadas práticas torturantes (de acordo com alguns autores, tais práticas também são conhecidas como as "provas ordálicas", já que esses institutos, frequentemente, são tratados como sinonímias) para provar a culpa ou inocência dos réus ou suspeitos. Pela sua brutalidade, tais práticas são recorrentes na literatura e cinematografia épica até os dias atuais, e constantemente são apontadas como o principal meio de prova da idade média.

Entre as práticas mais recorrentes ${ }^{29}$ estão a iudicium vomerum ignitorum (caminhada sobre relhas em brasa); a iudicum ferri igniti (segurar com as mãos objeto de metal em brasa); a manum in ignem mittere (deixar a mão sobre o fogo); a iudicium aquae ferventis (emergir o braço em água fervente, geralmente para apanhar um objeto); a iudicium aquae frigidae (mergulhar o réu amarrado na água de tanque, lago ou rio em

${ }^{27}$ LAGO, Cristiano Alves Valladares. op. cit. p. 08.

${ }^{28}$ DARESTE, Rodolphe. op. cit, p. 102.

${ }^{29}$ MAJZOUB, Milene Chavez Goffar. Juízos de Deus e Justiça Real no Direito Carolíngio. Campinas, Universidade Estadual de Campinas, 2005, pp. 42-43. 
ponto de congelamento), entre outras.

Também são relatadas práticas nem sempre torturantes, mas que visavam por vezes atestar a fé do réu, como a iudicium panis et casei (oferecimento de alimento consagrado para deglutição); e a purgatio per corpus et sanguinem Domini nostri Jesu Christi (oferecimento de hóstia consagrada para ingestão). Além dessas, outras provas eram "produzidas" para que se comprovasse a inocência de um ou de outro réu (ou suspeito), tais como a iudicium crucis (deixar os réus ou suspeitos com os braços em forma de cruz, e o primeiro que os deixasse cair seria o culpado), e a iudicium pugnae (que nada mais era que um duelo, por vezes considerado "sagrado", entre duas partes para comprovação do seu direito).

É extremamente complexo analisar, mais ainda compreender, o uso das provas dos iudicium Dei, ou das ordálias, na solução organizada de litígios, não sendo isso um dos objetos do presente estudo. Mas o fato é que seu declínio e gradual desaparecimento se deram a partir do Século XII ${ }^{30}$.

É notório que o desuso se deu em meio a profundas transformações sociais, eclesiais e, consequentemente, jurídicas, que motivaram o progressivo abandono dos iudicium Dei como meio de prova de direito. Ao que a literatura da história mundial indica, tais institutos foram reconhecidos como um problema histórico relevante, na medida em que se tornam incompatíveis com as novas organizações sociais e políticas da baixa idade média e com a nova ordem jurídica romano-canônica que se configurava.

Contudo, se por um lado com o resgate do Direito Romano e a influência da igreja, principalmente a partir do Século XI, a perícia começava a emergir com força entre os meios de prova, até mesmo em áreas pouco comuns e, portanto, frágeis à época, como a da falsidade documental, por outro, até aproximadamente o Século XII, o processo era "acusatório"31, ou seja, não havia processo sem acusação. Em outras palavras, os denunciantes, oficiais ou não, deviam apresentar aos encarregados de exercerem a função jurisdicional, fossem eles da realeza ou do clero, a acusação por escrito e oferecer ao menos os meios (ainda que arcaicos, em comparação aos dias atuais) de obtenção das respectivas provas.

A partir do Século XII, o "novo" ordenamento da Europa ocidental passou a desprezar as bases acusatórias do Direito processual vigente, sendo estabelecido, gradativamente, o sistema inquisitivo. Sem adentrar nos motivos históricos, que remetem

\footnotetext{
${ }^{30}$ MAJZOUB, Milene Chavez Goffar. op. cit. pp. 28-29.

${ }^{31}$ TOURINHO FILHO, Fernando da Costa. Processo Penal, v. 1, 32ª ed., São Paulo, Saraiva, 2010.
} 
à corrupção por parte de realezas e do clero, que iam diametralmente contra os interesses do Vaticano, à época, as regras do sistema acusatório passaram a ser ignoradas, comprometendo o contraditório, e consagrando a iniciativa ex officio (em tradução livre, de ofício) da acusação, cerceando, assim sensivelmente o direito de defesa aos acusados.

Tais como os peritos, os réus, nesse período, passaram a figurar meramente como fantoches no processo, agravando ainda mais a prática da tortura, em especial como meio de obtenção da confissão, até hoje, na maior parte dos ordenamentos, considerada a mais contundente das provas.

Vale observar que os resquícios de práticas de torturas, inclusive com a participação de expertos, em especial médicos, perduram até os dias atuais. Não por acaso, já no Século XX, o Código de Nuremberg deu embasamento ao Tribunal Penal Internacional para a condenação de práticas não muito distantes das provas ordálicas, que foram amplamente utilizadas, com os devidos "avanços" tecnológicos, durante o holocausto. Perduraram durante a Guerra Fria, e até hoje são questionadas em prisões como a de Guantánamo ${ }^{32}$. O mais agravante é que tais atos foram, no suceder da história, praticados por médicos (por inúmeras vezes também "peritos"); algo que não poderia deixar de ser mencionado, dadas as cicatrizes históricas que as práticas desses dois períodos nebulosos da perícia deixam até os dias atuais ${ }^{33}$.

\section{d) Avanços e retrocessos da perícia na baixa Idade Média e seus reflexos até os dias atuais}

Regressando à evolução histórica do Direito processual e do reconhecimento da perícia forense como parte indissociável do processo, mais precisamente aos nuviosos tempos de baixa idade média, sob a égide do Direito Canônico então vigente foi criado o "Santo Ofício", ou "Tribunal da Santa Inquisição", instituído para reprimir o sortilégio, a "magia", a heresia, o pecado, etc.; e que ficou conhecido pela sua arbitrariedade, total desrespeito ao que hoje se conhece por direitos humanos, ficando por isso temido e, pela rigidez, "respeitado" por toda a Europa de então, das ilhas ao continente.

Eis mais um retrocesso à atividade pericial, que ainda que "engatinhasse" antes da

\footnotetext{
${ }^{32}$ ARAUJO, Virginia Procópio de. O ato médico no crime de tortura. São Paulo, Faculdade de Direito da Universidade de São Paulo, 2012.

${ }^{33}$ Neste sentido, recomenda-se a leitura da dissertação de mestrado relacionada no item anterior, que exaure o tema do ato médico no crime de tortura, em especial a partir Século XX, até os dias atuais. Disponível em <http://www.teses.usp.br/teses/disponiveis/2/2136/tde-29102012-163521/pt-br.php>. Acessado em 28 dez. 2012.
} 
repressão do tribunal canônico, ao menos não deixava de respirar em esferas alheias ao Direito penal, vez que, desde muito antes, o Direito aprendeu rapidamente a resguardar os bens patrimoniais, enquanto a vida periclitava. Ainda que alguns autores tenham se esforçado por justificar o processo inquisitório, alegando que foi um "produto" de uma época notadamente cruel, e de ideias prepotentes, mas que acabou por constituir as bases do Direito penal na época moderna ${ }^{34}$, a verdade é que para o objeto do presente estudo, ou seja, a perícia forense, em especial a médica, o período foi parcamente produtivo.

Uma das escassas anotações positivas da época relata que, nesse período, uma vez constituídos os condados, a realeza outorgava as intituladas "Cartas", que determinavam direitos e privilégios (também denominadas "Foros") ${ }^{35}$, conceito que se estendia a todo tipo de território que fosse regido por preceitos fundamentais (ou por determinado códex). Nesse sentido, foi valiosa a importância de tais instrumentos nesse período, já que regulamentam os direitos de determinadas regiões, deliberando sobre o uso da terra, o que incluía, naquele tempo, questões sobre Direito penal, processual, e outros temas correlatos; e que embasariam, em um futuro ainda então distante, alguns preceitos fundamentais da perícia forense.

É bem verdade, todavia, que nem em toda a Europa da época estagnava ou a parcos passos se direcionava ao objeto do presente estudo, qual seja, a perícia forense. A Inglaterra, por exemplo, talvez em parte facilitada por seu distanciamento geográfico, seguia um rumo sensivelmente distinto do ordenamento jurídico europeu continental.

Afinal, já a partir do Século XII, a Inglaterra passou a adotar o sistema jurídico conhecido até os dias atuais como o Common Law (em livre tradução, Direito comum), que tem como maior diferencial em relação ao Civil Law (ou Direito civil, também assim, conhecido até os dias atuais, e adotada não apenas no Brasil, mas em todos os países cujo sistema jurídico teve suas bases na família romano-germânica do Direito) ter os costumes como a fonte mais importante do Direito, sendo o uso e a praxe os fundamentos básicos da jurisdição.

Nesta breve abordagem histórica, que é focada na evolução da perícia no Direito Ocidental, cabe uma rápida anotação, até por ser alheia ao tema central, sobre similaridades entre o Common Law e o Direito Islâmico. Muitas das bases do Direito Islâmico $^{36}$, que tiveram origens datadas de séculos antes do período de instauração do

\footnotetext{
${ }^{34}$ GONZAGA, João Bernardino. A inquisição em seu mundo. São Paulo, Saraiva, 1993, p. 27.

${ }^{35}$ ALMEIDA JUNIOR, João Mendes de. op. cit.

${ }^{36}$ DARESTE, Rodolphe. op. cit, pp. 53-54.
} 
Common Law, na Inglaterra, parecem ter encontrado espaço na ilha mais nobre da então Europa setentrional. E essa similaridade está refletida em templos e organizações de universidades à época ${ }^{37}$. Curioso é que quase um milênio depois exista uma guerra, tão sangrenta quanto velada, entre o hoje mais rico país da Common Law, os Estados Unidos, e vários diversos países de origem islâmica, sem quase nunca ser mencionado que seus sistemas jurídicos possuem laços estreitos em suas raízes históricas.

Em regresso às ponderações sobre as características do Common Law, essa forma peculiar do exercício de jurisdição, por certo, afastou o Direito Inglês dos modelos romano e germânico que então vigorara no restante da Europa, possibilitando a introdução, na Inglaterra, de um mecanismo de recursos aos cases (em tradução livre, julgados precedentes), que eram registrados em livros e serviram como algo análogo a súmulas vinculantes (também conhecidos como Year Books ${ }^{38}$, que traziam o compêndio das decisões proferidas ao longo de cada ano pelos tribunais), e que orientavam os julgamentos em consonância com os "costumes" consagrados nas decisões anteriormente proferidas.

Ainda que posteriormente, por volta do Século XV, o Common Law inglês gradativamente passasse a adotar a equity (que tem por livre tradução "jurisdição de equidade"), e que se aproximava do processo escrito, consagrado pelo direto canônico, essa fase do Common Law admitiu, de forma revolucionária para a época, a figura do expert witness, que era já tradicional na civilização Celta, incluindo os relatos da vida de Adomnán de Iona, posteriormente reconhecido santo e autor da "Lei dos Inocentes" (por muitos considerada um esboço da futura Convenção de Genebra e da Lei Fundamental dos Direitos Humanos) $)^{39}$. Dessa forma, a figura do perito, ainda que ligeiramente distante da forma que hoje se concebe, encontrou espaço nesse período do ordenamento jurídico inglês, que séculos depois vivenciou a integração da equity com a Common Law, e que viria a influenciar todas as futuras colônias e, consequentemente, até mesmo os tradicionais sistemas da família romano-germânica do Direito nos Séculos XX e XXI, conforme será mais bem detalhado adiante, em capítulos específicos.

Não obstante, no restante do ordenamento jurídico ocidental, outras influências passavam a ser exercidas, transformando gradativamente a realidade de parte desses

${ }^{37}$ DEVICHAND, Mukul. Is English law related to Muslim law?. Londres, 2008. Disponível em: $\langle$ http://news.bbc.co.uk/2/hi/uk_news/magazine/7631388.stm〉. Acessado em: 02. Jan. 2013.

${ }^{38}$ LAGO, Cristiano Alves Valladares. op. cit. p. 16.

${ }^{39}$ ELLIS, Peter Barresford. The Celtic Empire. Durham, Estados Unidos da América, Carolina Academic Press, 1990. 
ordenamentos.

Na península ibérica, por exemplo, foi marcante a influência árabe nesse período. A influência da escola jurídica Malikita (assim denominada devido ao seu principal teórico, Malik ibn Anas), que teve por um de seus pilares lutar contra os vereditos religiosos, foi marcante no pensamento dos filósofos de Córdoba ${ }^{40}$, que trouxeram à luz do conhecimento diversos estudos sobre medicina, astronomia, física, alquimia, entre outras ciências.

Um dos maiores expoentes filosóficos da escola de Córdoba foi Averróis (adaptação latina para o nome original árabe de Abu al-Walid Muhammad ibn Ahmad ibn Muhammad ibn Ruchd). Aluno de Malik, foi criado em uma família de juristas, se formou médico, e se consagrou como um dos mais eminentes comentadores islâmicos de Aristóteles (imputa-se, inclusive, a Averróis a "redescoberta" da filosofia aristotélica na Europa) e, como tal, foi ferrenho defensor da separação entre fé e razão.

Ainda que o pensamento árabe não fosse uma simples extensão ou adaptação de conteúdo dos filósofos clássicos, vez que existiam divergências oriundas principalmente em relação ao islamismo ${ }^{41}$, se formaram correntes ligadas aos clássicos helenistas, essencialmente racionalistas, entre outras correntes adeptas da tradição grega e, portanto, demonstrativas. Embora, de certa forma, algumas correntes fossem ainda adeptas de provas de cunho religioso, o princípio demonstrativo, nessa fase da história, fora, de forma marcante direcionado para as ciências, em detrimento de crenças outrora prevalecentes. Em vista disso, é possível afirmar que os árabes se tornaram os precursores do método experimental no ocidente ${ }^{42}$. Como se denota, novamente, de forma análoga ao descrito sobre o Common Law, é possível ser traçado um paralelo entre as origens dos ordenamentos jurídicos da atualidade (ainda que, nesse caso, restritamente com relação aos meios de prova) com o Direito Islâmico.

A obra de Averróis teve repercussão tanto no oriente como no ocidente ${ }^{43}$, sendo que, no oriente, houve perseguição por parte de grupos fundamentalistas, enquanto no ocidente, até anos após sua morte, a igreja ainda não aceitava a divisão entre filosofia e teologia.

\footnotetext{
${ }^{40}$ NASCIMENTO JUNIOR, Antonio Fernandes. "Fragmentos da história das concepções de mundo na construção das ciências da natureza: das certezas medievais às dúvidas pré-modernas". In: Ciência \& Educação, v.9, n. 2. Bauru, Unesp, 2003, p. 282.

${ }^{41}$ GROS, G. M. "A primeira história andaluza das ciências”. In: CARDAILLAC, L. (Org.). Toledo, século XII-XIII: muçulmanos, cristãos e judeus: o saber e a tolerância. Rio de Janeiro: Zahar, 1992. p. 179.

${ }^{42}$ JUNIOR, Antonio Fernandes Nascimento. op. cit. p. 283.

${ }^{43}$ SILVA, Alexandre Alberto Gonçalves. op. cit., p. 25.
} 
Entretanto, grande parte do conhecimento árabe produzido no período foi transcrito para o latim, após a reconquista pelos cristãos de parte da península ibérica, visto que, após o Século XII, a ocupação árabe ficou restrita à região então denominada Al-Andalus, que ficou posteriormente restrita ao reino de Granada, até a derradeira integração da região à Espanha ${ }^{44}$. Nesse contexto, a região, em especial a cidade de Toledo teve papel relevante no processo de tradução desses documentos, concentrando grande número de tradutores e estudiosos. Tal fato coincide, inclusive, com a fundação de universidades na região nesta época ${ }^{45}$.

Como resultado, diversos textos de filósofos gregos, então sem tradução, foram colocados aos universitários, aprofundando os estudos da filosofia aristotélica, à época praticamente desconhecidos no ocidente, e, em particular, entre os cristãos. Além da filosofia, da astronomia, e de outras ciências, também despertaram interesse as traduções das ciências médicas, com destaque para a obra de Claudius Galenus (ou também Cláudio Galeno, em livre adaptação), ora conhecido como o "pai" das pesquisas fisiológicas, e que inspirou, inclusive, a obra de Andreas Versalius, belga contemporâneo de Abroise Paré, e considerado o "pai" da anatomia moderna, que teve em seu currículo ter servido à corte dos reis espanhóis Carlos I e seu sucessor Filipe II, período em que elaborou obras primas da anatomia, como as Tabulae Anatomicae Sex e a Fabrica ${ }^{46}$, resultado de incontáveis dissecações e, também assim possível denominar, perícias.

Fica evidenciado, portanto, a convergência do conhecimento, em relativamente curto lapso temporal, naquela região. Com os recém introduzidos conhecimentos, a igreja passou por transformações, passando a propor, inclusive, novas interpretações dos textos sagrados. A partir desse momento começaram a surgir questionamentos às hierarquias eclesiásticas, bem como o poder e riqueza dos clérigos e do papado, chegando até mesmo a serem relatados movimentos insurgentes da igreja que pregavam o regresso à simplicidade e à modéstia do cristianismo de origem ${ }^{47}$.

A partir de então, principalmente nos centros urbanos insurgentes, o clero passou a ser perseguido ideologicamente, fazendo com que a igreja reforçasse algumas de suas

\footnotetext{
44 MORERA, Darío Fernandez. "The mith of Andalusian Paradise". In: The Intercollegiate Review, Wilmington, Estados Unidos da América, ISI, outono 2006, p. 23-24.

45 BEZARES Luis E. Rodríguez San Pedro, RODRÍGUEZ, Juan Luis Polo. Universidades Hispánicas: Colegios y Conventos Universitarios en la Edad Moderna. Salamanca, Ediciones Universidad Salamanca, 2009. p. 10.

${ }^{46}$ A obra de VERSALIUS, Andrea, De Humani Corporis Fabrica, libri septem, que fora derivada para Fabrica, está disponível em <http://archive.nlm.nih.gov/proj/ttp/flash/vesalius/vesalius.html〉. Acessado em 28. Dez. 2012.

${ }^{47}$ SILVA, Alexandre Alberto Gonçalves. op. cit., p. 26.
} 
instituições como forma de combater a este cenário. Nesse momento ganham forças algumas ordens da igreja, como a ordenação Dominicana (fundada na França em 1216, pelo sacerdote espanhol Domingos de Gusmão, e que teria, em 1276, seu primeiro papa, Inocêncio V) e a ordenação Franciscana (com origem nos Frades Franciscanos Conventuais, em 1209, que em 1288 teria seu primeiro papa, Nicolau IV) ${ }^{48}$

Nesse cenário, a principal atribuição filosófica e política dos Dominicanos era o combate às "heresias" nas lutas ideológicas, atuando em ruas e praças das vilas e das incipientes cidades, até chegar às universidades, tendo em Tomás de Aquino um de seus principais expoentes na época. Por sua vez, os Franciscanos defendiam a simplicidade, dando corpo a alguns movimentos então heréticos da época que questionavam a hierarquia da igreja nos primeiros anos, até obter o reconhecimento dessas vertentes pelo papado.

Além das convicções teológicas, faziam parte dos estudos e ensinamentos franciscanos conhecimentos nas áreas da física, astronomia, medicina e alquimia, tendo encontrado respaldo a tais estudos na fundação da Universidade de Oxford, que foi concebida em um ambiente de liberdade de desenvolvimento de áreas então "alternativas" do conhecimento, ao contrário do que ainda acontecia na maior parte da Europa continental. Com expoentes como Robert Grosseteste (fundador da Escola Franciscana de Oxford), Roger Bacon (aluno de Grosseteste e que definiu de forma revolucionária para a época o método científico como ciclos de observação, hipóteses, experimentação e de verificação independente), e Guilherme de Ockham (professor prérenascentista de Oxford, representante do Nominalismo e comentador de Aristóteles) ${ }^{49}$, os franciscanos foram fundamentais para o ingresso dos conhecimentos originalmente trazidos pelos árabes ao ordenamento jurídico ocidental.

Com essas novas ideias difundidas em diferentes partes da Europa, o modelo medieval de ensino restou definitivamente abalado, até pela necessidade de maior embasamento técnico nos estudos relacionados ao desenvolvimento das cidades e dos trabalhos dos artesãos. A necessidade de método para a realização de obras e artefatos, aos poucos, fez com que passasse a ser aceito o empirismo de Oxford como caminho para o encontro da verdade em praticamente todas as áreas do conhecimento. Dessa forma o conhecimento adquirido por experiências que podiam gerar certezas, ou

\footnotetext{
${ }^{48}$ GRIGULEVICH, Iosif Romualdovitch. KUZNETSOV, M. (Trad.). Historia de la Inquisición. Moscou, Editora Progresso, 1980.

${ }^{49}$ SILVA, Alexandre Alberto Gonçalves. op. cit., p. 29.
} 
indutivo, passou a ser assumido como verdade, o que, como se pode presumir, teve enorme impacto nos rumos e na evolução da perícia, que finalmente passava a encontrar espaço definitivo no ocidente.

A partir do Século XIV, são encontrados os primeiros registros de perícias realizadas de forma próxima à concepção moderna de perícia. Embora, por vezes, ainda confundida com o exame judicial e o juízo arbitral, é possível afirmar que, ao final da idade média e início da idade moderna, já existiam pessoas que, estudadas ou conhecedoras de determinadas ciências e artes, realizavam o exame de coisas ou pessoas como profissão ${ }^{50}$, inclusive para fins judiciais.

\section{e) Os caminhos para o reconhecimento da perícia enquanto ciência na Era pré Moderna}

A partir do Século XV, os avanços técnicos e científicos passaram a ter uma maior velocidade. Começavam então as conquistas dos "novos mundos" através da navegação, ao mesmo tempo em que se intensificava o comércio, o que fez com que o ocidente adotasse de forma massiva os algarismos arábicos, até como forma de mensurar estoques, produções e riquezas.

Nos anos subsequentes, diversos estudiosos da época surgiram com grande destaque, como Leonardo da Vinci, que, entre o final do Século XV e início do Século $\mathrm{XVI}^{51}$, trazia ao conhecimento do mundo suas obras, de caráter totalmente interdisciplinar. Já no campo da medicina, nesse período, outros personagens ilustres, ainda que controversos, marcaram a história do período, a exemplo de Phillipus Aureolus Theophrastus Bombastus von Hohenheim, conhecido por Paracelso, e que ficou famoso por se insatisfazer com os conhecimentos do ocidente, na época, e buscar, em viagens ao oriente, respostas para suas pesquisas. Tido como o "pai” da bioquímica ${ }^{52}$, além de ter revolucionado a forma como se viam os medicamentos e os tratamentos médicos em geral, Paracelso estudou as moléstias de trabalhadores, defendendo a tese de que determinadas moléstias tinham origem em partes específicas do organismo e, sob esse ponto de vista, os tratamentos deveriam ser resultados de ações químicas sobre os

\footnotetext{
${ }^{50}$ SILVA, Alexandre Alberto Gonçalves. op. cit., p. 31.

${ }^{51}$ A+E Television Networks, LLC. Leonardo da Vinci Biography. Nova Iorque, Estados Unidos da América, 2012. Disponível em: <http://www.biography.com/people/leonardo-da-vinci-40396>. Acessado em: 28 dez. 2012.

52 Enyclopaedia Britannica. Paracelsus. Londres, Enyclopaedia Britanica, Inc., 2012. Disponível em: <http://www.britannica.com/EBchecked/topic/442424/Paracelsus $>$. Acessado em 28 dez. 2012.
} 
organismos, procurando em práticas científicas o meio para a cura. Nesse sentido, a observação dos efeitos químicos sobre os corpos foram de grande importância para o desenvolvimento das investigações sobre causa mortis, que futuramente evoluiriam para os exames necroscópicos.

A busca de um método eficaz para a construção do conhecimento a respeito da natureza ganhou novas direções, anos depois, com René Descartes (também conhecido por Renatus Cartesius), já no início do Século XVII e, coincidentemente, da idade moderna. Defendia Descartes como verdadeira ciência aquela que fosse útil à humanidade. Dessa forma, priorizou as investigações experimentais, e afirmou que, com o avanço da filosofia natural, a medicina seria capaz de curar enfermidades do corpo e da mente, assim como os efeitos do envelhecimento.

Ainda que notoriamente dedicado à matemática, a qual alegava apresentar conceitos objetivos e distintos, posto que gerados por métodos, independentes dos sentidos, defendia Descartes que, apesar de as ciências serem múltiplas, o método deveria ser único, orientado por um acordo fundamental, pautado nas leis da natureza e da matemática. Desse modo, a ciência defendida por Descartes constituía-se por descrever seres e coisas a partir da oscilação de cada parte dos corpos estudados, incluindo as modificações relacionadas a todas as suas características, de forma que a natureza não fosse algo místico ou mágico, mas sim uma máquina, constituída apenas de matéria e movimento. O mesmo aplicava, portanto, aos seres vivos, sendo que, segundo Descartes, todas as funções humanas se resumiam a ações mecânicas, matemáticas, lógicas e explicáveis ${ }^{53}$. Esse raciocínio foi fundamental para a metodologia que orientou a forma da busca da verdade e do conhecimento, nos séculos que se seguiram, incluindo, neste universo as perícias.

Nessa época foi marcada a limitação total do ensinamento do Direito Romano em solo francês, como forma de busca do fortalecimento da monarquia francesa. Desde a bula Super Specula, editada pelo papa Honório III, séculos antes, já existia tal limitação, mas, em 1579, essa restrição ganhou nova força, pela Ordenança de Blois, editada por Henrique III, e reafirmada, em 1609, por Henrique IV $^{54}$, sendo que somente sob o reinado de Luís XIV, já na segunda metade do Século XVII, o ensino do Direito Romano regressou como disciplina em solo francês.

${ }^{53}$ DESCARTES, René. JUNIOR, Bento Prado (Trad.), Descartes. In: Os pensadores. vol. XV. São Paulo, Abril Cultural, 1973.

${ }^{54}$ MARTINS, Adilton Luís. "Pensar as Origens". In: História: Questões \& Debates, n. 48/49, Curitiba,

Editora UFPR, 2008, pp. 220-221. 
E a Ordenança de Blois não apenas ficou marcada na história por essa restrição, mas também por trazer, em seu texto, de forma expressa, que o valor das coisas seria decidido por peritos, em detrimento de julgadores ou testemunhas. Diante dessa nova obrigatoriedade, se formou uma associação corporativa de peritos oficiais ${ }^{55}$, que serviam de auxiliares aos juízes franceses da época em questões de cunho técnico.

Entretanto, esse período teve relativamente curta duração, vez que diante da escassez de profissionais habilitados, além de casos de abusos por parte dos peritos ${ }^{56}$, em 1667, houve retrocesso nesse sentido, quando Luís XIV retomou diversas práticas do Direito Romano, entre elas a concessão às partes da possibilidade de escolherem uma pessoa de confiança para avaliar, examinar e quantificar coisas ou danos em discussão em juízo. E tal situação perdurou desde o final do Século XVII até e XVIII, mas principalmente até a Revolução Francesa de $1789^{57}$, quando teve início o período moderno.

E nesse período de novos alicerces da administração judiciária diminuíram as características inquisitoriais dos procedimentos processuais penais franceses, com o advento de ideias humanistas defendidas pelo movimento científico. Foi nessa época que surgiram na França os ideais defendidos por Charles de Montesquieu, Voltaire, JeanJacques Rosseau, Cesare Bonesana Beccaria, entre outros célebres filósofos e cientistas sociais que marcaram a humanização do Direito penal e processual penal, sendo até hoje de estudo obrigatório em praticamente todas as escolas jurídicas, em todo o mundo, influenciando todos os modernos ordenamentos jurídicos.

\section{f) A perícia no reino de Portugal e as primeiras leis vigentes no "Novo Mundo"}

Já no que tange ao Direito Português, que em virtude da fase das grandes navegações e descobertas, conforme anteriormente descrito, seria o primeiro sistema jurídico a vigorar no território atual do Brasil. No Século $\mathrm{XV}$, entravam em vigor as Ordenações Afonsinas (também conhecidas como "código Afonsino") que constituíram possivelmente o primeiro códex português da era moderna. De forma abrangente (para a época) era composto de cinco livros, sendo que o primeiro regulava os cargos da administração e da justiça; o segundo, a relação entre o Estado e a igreja, bem como dos

\footnotetext{
${ }^{55}$ SANTOS, Moacyr Amaral. op. cit.

${ }^{56}$ SILVA, Alexandre Alberto Gonçalves. op. cit., p. 40.

${ }^{57}$ LAGO, Cristiano Alves Valladares. op. cit. p. 12.
} 
bens e privilégios da igreja, incluindo os direitos régios e sua cobrança, a jurisdição dos donatários e as prerrogativas da nobreza; o terceiro, essencialmente regulava o processo civil; o quarto, o Direito civil propriamente dito, incluindo as regras referentes a contratos, testamentos, tutelas, formas de distribuição e aforamento, de terras, e assuntos correlatos; e o quinto e último abordava questões referentes ao Direito penal, incluindo a tipificação dos crimes e as suas respectivas penas ${ }^{58}$.

No que tange às perícias, o código Afonsino, em seu Livro I, Título XII ("Dos procuradores, e dos que não podem constituir procuradores", em tradução livre), trazia,

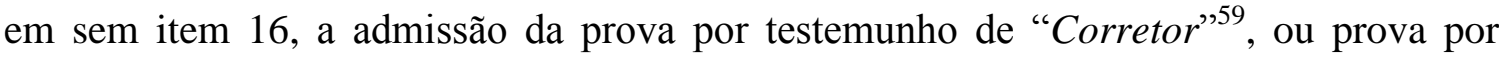
arbitramento em comum acordo das partes, que era assemelhada a uma espécie de perícia, possivelmente no meio termo entre o perito do ordenamento jurídico do Civil Law da atualidade, e o expert witness, do Common Law; mas já diferido da figura do julgador do Direito Romano clássico.

Merece destaque, nessa passagem, que o código Afonsino era um códex quase completo, que abordava praticamente todas as matérias administrativas do Estado português e que, segundo os registros históricos, possivelmente foi o primeiro desse tipo publicado na Europa, na época em que se formava a cultura renascentista. Dessa forma, teve extrema importância na restrição às regras feudais e consuetudinárias, constituindo o ponto de cisão entre a legislação feudal e a reforma pretendida pela realeza da época ${ }^{60}$.

O código Afonsino foi então sucedido pelas Ordenações Manuelinas, editadas pelo rei Manuel I, ao final do Século XV, e que tinham por base o código Afonsino, com algumas inovações. Estas incluíam, no campo da perícia, um trecho específico que descrevia o que à época se podia denominar "peritos”, mais precisamente em seu livro III, título LXXXII (entitulado "Dos Aluidradores, que quer tanto dezer como Aualiadores, ou Estimadores") ${ }^{61}$. Os “aluidradores", ou "estimadores', nada mais eram senão peritos, que auxiliavam a justiça na quantificação de bens ou danos. Ainda que o texto original utilizasse expressões como "afeiçoar o ódio", posto que foram enviados

\footnotetext{
${ }^{58} \mathrm{O}$ texto original das Ordenações Afonsinas está disponível no site da Universidade de Coimbra, Portugal, em: 〈http://www1.ci.uc.pt/ihti/proj/afonsinas/>. Acessado em 03 jan. 2013.

59 Conforme texto original das Ordenações Afonsinas, Livro I, Título XIII, Item 16. Disponível em: $<$ http://www1.ci.uc.pt/ihti/proj/afonsinas/11p90.htm>. Acessado em 03 jan. 2013.

${ }^{60}$ ALMEIDA, Cândido Mendes de (Org.). Codigo Philippino ou Ordenações e Leis do Reino de Portugal. $14^{\mathrm{a}}$ ed., Rio de Janeiro, Tipografia do Instituto Filomático, 1870. Disponível em: $\langle$ http://www.iuslusitaniae.fcsh.unl.pt/verobra.php?id_obra=65>. Acessado em 28. dez. 2012.

61 Conforme texto original das Ordenações Manuelinas, Livro III, Título LXXXII. Disponível em: <http://www.ci.uc.pt/ihti/proj/manuelinas/13p307.htm>. Acessado em 03 jan. 2013.
} 
pelos "santo evangelho" "62, que denotam que os profissionais deveriam obedecer regras "sagradas", e não absolutamente técnicas, esses deviam auxiliar em questões objetivas e baseadas no conhecimento, as lides existentes nas vilas e cidades, por conta de seu notório conhecimento nos assuntos então em discussão.

O texto trazia, porém, uma ressalva no sentido de que caso os juízes entendessem por bem escolher um "aluidrador" que não fosse aceito pelas partes, seria salvaguardado o interesse comum pelo juiz. E mais ainda, no caso de decisão de mais de um "aluidrador", as partes poderiam recorrer ao juiz sobre a decisão deles ${ }^{63}$. É curioso que, embora de forma arcaica, o texto parece dar forma a diversos regulamentos de câmaras arbitrais existentes em pleno Século XXI, que embora tenham evoluído na questão de solução de disputas, incluindo decisões em mais de uma língua, têm irrefutavelmente similaridade com o código Manuelino em sua forma.

Em virtude do domínio castelhano, ao fim da união ibérica, o código Manuelino foi sucedido pelas Ordenações Filipinas (de Filipe II de Espanha, ou Felipe I de Portugal). De acordo com os registros históricos, elas tiveram dificuldades de prevalecer em Portugal, devido à ausência de originalidade do texto, com pouca clareza (em parte devido às diferenças linguísticas regionais) e frequentes contradições, que provavelmente tiveram por causa excessiva repetição do texto consagrado pelo código Manuelino. O que não impediu que se tornasse o mais duradouro código legal português, permanecendo em vigência até 1830, duração essa improvável para a época, mas explicável diante das pressões vividas pela corte no período, em especial as ameaças impostas pelo exército liderado por Napoléon Bonaparte ${ }^{64}$.

Em tese (posto que os relatos históricos são imprecisos), o surgimento do Brasil enquanto território do reino português foi regido pelas Ordenações Manuelinas e Filipinas, sendo a primeira vigente nos primórdios da colonização. Ao longo da fase Manuelina no "Novo Mundo" desembarcavam pessoas indistintamente e, seguindo o "exemplo" da Inglaterra, foram enviados criminosos condenados na sede da corte às colônias, no intuito de povoar o novo território recém descoberto ${ }^{65}$, segundo citado por algumas fontes históricas.

62 Conforme texto original das Ordenações Manuelinas, Livro III, Título LXXXII. Disponível em: $<$ http://www.ci.uc.pt/ihti/proj/manuelinas/13p308.htm>. Acessado em 03 jan. 2013.

${ }^{63}$ Conforme texto original das Ordenações Manuelinas, Livro III, Título LXXXII. Disponível em: <http://www.ci.uc.pt/ihti/proj/manuelinas/13p309.htm>. Acessado em 03 jan. 2013.

${ }^{64}$ HOBSBAWN, Eric J; PENCHEL, Marcos (Trad.) Era das Revoluções - 1789 -1848. 25 a ed, São Paulo, Paz e Terra, 2009.

${ }^{65}$ STADEN, Hans. Duas viagens ao Brasil. São Paulo, L\&M Pocket, 2008. 
Agrava esse cenário o fato de que, ainda na vigência das Ordenações Manuelinas, foi instituído, no atual território brasileiro, o regime de capitanias hereditárias, que baseado no conceito do antigo território romano, constituía uma área independente, livre de encargos e obrigações. Nesse contexto, o rei emancipou o território extracontinental como "feudos" do reino, outorgados a serviço da fé, passando a comandar essas terras bispos e nobres de primeira importância à metrópole, ora em ebulição por conta das ameaças de invasão, em evidência, e notadamente agravadas pelas descobertas portuguesas $^{66}$.

Com a cada vez mais crescente ocupação das novas terras, os feudos se transformaram em vilas, as quais aos poucos se tornavam municípios e adquiriam, de forma cada vez mais marcante, as características de cidades completas e, como tais, constituíram os primeiros núcleos da administração civil no Brasil. Nasciam, então, as capitanias hereditárias brasileiras, onde os donatários eram, além de governadore,s os administradores da justiça em seus territórios.

Passavam, nesta época, a vigorar, no Brasil, as ordenações portuguesas, que permaneceram em vigor até a promulgação da "Constituição Política do Império do Brazil”, em $1824^{67}$. Esta, por sua vez, perdurou até a proclamação da república no Brasil, e sua "Constituição da República dos Estados Unidos do Brasil”, em $1889^{68}$. A partir de então o ordenamento jurídico brasileiro passou a ganhar contornos próprios, incluindo a alternância de períodos democráticos e ditatoriais (alguns, como se discutirá adiante, em desfavor da perícia), até tomar as formas atuais.

\section{g) A Era das Revoluções, inclusive para a Medicina Legal}

A partir da Revolução Francesa de 1789, a exemplo de outros institutos dos Estados, os ordenamentos jurídicos, a começar pelo próprio ordenamento francês, passaram por profundas modificações ${ }^{69}$. Entre elas, tem reflexo direto no presente estudo as alterações no Direito processual. Em 1808, Napoléon Bonaparte promulgou o Code d'Instruction Criminelle, que dizimou as práticas jurídicas secretas e inquisitoriais que a Europa vivenciou em séculos anteriores.

\footnotetext{
${ }^{66}$ SILVA, Alexandre Alberto Gonçalves. op. cit., p. 41.

${ }^{67}$ Disponível em <http://www.planalto.gov.br/ccivil 03/Constituicao/Constitui\%C3\%A7ao24.htm>. Acessado em 13 jan. 2013.

${ }^{68}$ Disponível em < http://www.planalto.gov.br/ccivil_03/constituicao/constitui\%C3\%A7ao91.htm>. Acessado em 13 jan. 2013.

${ }^{69}$ HOBSBAWN, Eric J; PENCHEL, op. cit.
} 
Pautado na publicidade, o códex francês tornou público os trabalhos dos juízes, bem como o parecer dos médicos. Antes desse período, a venalidade e a incompetência de peritos e juízes, em diversos julgamentos, eram acobertados pelo caráter sigiloso dos pareceres $^{70}$.

Neste período, os médicos oficiais eram responsáveis tanto pelos pareceres da justiça, quanto pela implementação de políticas de saúde pública. Diante dos ideais sociais da Revolução, e o crescente interesse pelo bem estar social, em especial como forma de evitar epidemias que acometiam principalmente a plebe e a burguesia, a Medicina Pública ganhou destaque e, consequentemente, os peritos.

É nesse época, mais precisamente em 1829, que surge o primeiro periódico para publicação de trabalhos em Medicina Legal, na França, o Annales d'Hygiène Publique et de Médecine Légale ${ }^{71}$. Essa e outras publicações subsequentes permitiram que os avanços e descobertas do campo da física, química e biologia fossem incorporados à Medicina Legal e, consequentemente, aplicados na confecção de laudos.

A segunda metade do Século XIX, portanto, foi marcada pela aplicação do método científico às ciências médicas e com isso, gradativamente, a Medicina Legal passou a ser definitivamente considerada uma ciência, adquirindo já, nessa época, um status próximo ao dos dias atuais, sendo incorporada a praticamente todos os cursos de Medicina e de Direito. As variações que encontrou, a partir desse período, se deram pela adoção de diferentes tratamentos que encontrou nos diversos ordenamentos jurídicos, bem como nas paulatinas evoluções das técnicas, mas é possível afirmar que é exatamente a mesma ciência desde então e, portanto, a partir desse momento histórico, se faz presente a perícia tal qual conhecemos atualmente.

\section{h) A perícia médico legal e a Medicina Legal no Brasil}

A perícia forense no Brasil se confunde com a própria história do Direito no país, uma vez que já era prevista nos ordenamentos que inspiraram nossos códigos. Por esse motivo, este estudo tratará, de forma mais detalhada, a perícia médico forense, que afinal, é o cerne da presente discussão. Esta, por sua vez, guarda íntima relação com a história da Medicina Legal no Brasil, conforme se passa a descrever adiante.

\footnotetext{
${ }^{70}$ HÉRCULES, Hygino de C. op cit, p. 7.

${ }^{71}$ Cópia integral disponível em 〈http://www.biusante.parisdescartes.fr/histmed/medica/cote?90141 >. Acessado em 03 jan. 2013.
} 
Até pelo pioneirismo, a principal influência da Medicina Legal brasileira em suas origens foi francesa, destacando-se, também as influências alemã, italiana e portuguesa. Sua nacionalização teve início por volta de 1860, com o primeiro curso de prática tanatológica forense do Brasil no Rio de Janeiro, concretizando-se na Bahia, cerca de duas décadas depois, com Raimundo Nina Rodrigues, que deu início à pesquisa médico legal a partir da realidade brasileira ${ }^{72}$

Após esse período, surgiu um dos maiores expoentes da especialidade até hoje, Oscar Freire de Carvalho, que vindo da Bahia para São Paulo, em 1913 foi convidado por Arnaldo Vieira de Carvalho a reger a cátedra de Medicina Legal da recém criada Faculdade de Medicina e Cirurgia de São Paulo, que posteriormente integraria a Universidade de São Paulo. O prédio onde inicialmente estava abrigada a cátedra de Anatomia, regida por Alfonso Bovero, anos mais tarde viria a abrigar o Instituto de Medicina Legal, a partir de 1922, hoje denominado Instituto Oscar Freire, que atualmente faz parte do Departamento de Medicina Legal, Ética Médica e Medicina Social e do Trabalho da Universidade de São Paulo.

No campo do Direito, em 1832, o então "Código de Processo Criminal" 73 estabeleceu a perícia oficial para a realização de exames de corpo de delito no Brasil. Nesse mesmo ano, a Medicina Legal passou a ser disciplina obrigatória em algumas faculdades de Medicina e Direito, e muitos dos dispositivos do antigo código de 1832 foram apenas adaptados ao longo dos anos e continuam vigentes no atual Código de Processo Penal.

Entretanto, a regulamentação da atividade médico pericial viria a ocorrer apenas em 1854, através do Decreto $\mathrm{n}^{\circ} 1.740$ daquele ano, quando foi criada, junto à então Secretaria de Polícia da Corte a "Assessoria Médico-Legal”, à qual cabia realizar "exames de corpo de delito e quaisquer exames necessários para a averiguação dos crimes e dos fatos como tais suspeitados"74. Ainda assim, a Medicina Legal só viria a ser incluída como cátedra nos cursos de Direito, a partir de 1891, a partir de proposição do então deputado Rui Barbosa.

Atualmente, a prática médico legal no Brasil é uma atividade oficial e pública, com Institutos Médico Legais em todo o país, com uma sede central em cada uma das

\footnotetext{
${ }^{72}$ SOCIEDADE BRASILEIRA DA HISTÓRIA DA MEDICINA. Raimundo Nina Rodrigues. Disponível em $<$ http://www.sbhm.org.br/index.asp?p=medicos_view\&codigo=200>. Acessado em 03 jan. 2013.

${ }^{73}$ Disponível em <http://www.planalto.gov.br/ccivil 03/Leis/LIM/LIM-29-11-1832.htm>. Acessado em 13 jan. 2013.

${ }^{74}$ FRANÇA, Genival Veloso de. Medicina Legal. $9^{\text {a }}$ Ed. Rio de Janeiro, Guanabara Koogan, 2012., p. 06.
} 
capitais dos Estados, além do Distrito Federal. O laudo, portanto, pode ser considerado um ato administrativo, e tem valor de documento oficial, o que adiante se discutirá de forma mais detalhada, com relação aos benefícios e prejuízos que isso acarreta. 


\section{V - REALIDADE ATUAL DAS PERÍCIAS MÉDICO LEGAIS NO BRASIL, EM ESPECIAL NO ESTADO DE SÃO PAULO}

Para a compreensão dos problemas existentes na utilização de laudos periciais no sistema jurídico atual é imprescindível analisar o funcionamento da polícia científica, sua estrutura e sua sistemática de elaboração dos laudos. Para tanto, como limitação, será enfocado o Estado de São Paulo, não apenas por conta do aspecto geográfico, ou seja, o principal local onde o presente estudo foi conduzido, mas também por ser São Paulo o Estado que mais realiza perícias no país.

A partir dessa premissa, enquanto amostragem, as constatações podem refletir os acertos e falhas que se verificam em âmbito nacional. Mais além, ainda que os dados colhidos estejam, em sua maior parte, voltados à esfera local, as conclusões certamente se aplicam não apenas ao Brasil, mas também têm relevância às práticas semelhantes verificadas em ordenamentos jurídicos estrangeiros, em especial, aqueles que têm por raízes o Civil Law, conforme pretende se demonstrar nas conclusões do presente estudo.

\section{a) Problemas advindos da delegação de responsabilidades}

$\mathrm{Na}$ maioria dos ordenamentos jurídicos da atualidade, independente da tradição jurídica local, é senso comum que quando acontece um crime ou haja uma ocorrência que resulta em danos à pessoa, incluindo óbitos, a força policial precisa estar completa no local, incluindo o perito, o investigador e o policiamento ostensivo para garantir o devido isolamento da área. Isso, porém, não se verifica na maior parte do Brasil, no que se inclui a realidade do Estado de São Paulo.

Em São Paulo, por exemplo, frequentemente são constatadas "desinteligências" entre as forças policiais, que entre si discutem as competências dos agentes de segurança, e até mesmo de saúde, para realizar determinadas funções. Como ilustração desse problema, recentemente, foi travada fervorosa discussão com relação à competência para atendimento a vítimas, em virtude da necessidade de preservação das cenas de possíveis crimes, que motivou a publicação de uma controversa resolução da Secretaria de Segurança Pública ${ }^{75}$.

Em referida resolução, publicada após indícios de crimes supostamente cometidos

${ }^{75}$ GOVERNO DO ESTADO DE SÃO PAULO. Secretaria de Segurança Pública. Resolução SSP-05/2013. São Paulo, Diário Oficial - Poder Executivo, 08 jan. 2013, p. 123. 
por autoridades policiais (possivelmente em virtude de retaliação à ação de facções criminosas), proibiu-se o atendimento de policiais às vítimas de lesões corporais graves, de homicídio, de tentativa de homicídio, de latrocínio e de extorsão mediante seqüestro, resultando em morte. Determinou-se, então, que a competência para atendimento a essas ocorrências deve ser exclusiva do Serviço de Atendimento Móvel de Urgência - SAMU, posto que ele teria, de acordo com o texto da resolução, "protocolo de atendimento de ocorrências com indícios de crime buscando preservar evidências periciais". Presume-se, com isso, que o executivo entendeu que policiais militares e outros agentes policiais poderiam prejudicar as evidencias indispensáveis à perícia.

Restou evidenciado, portanto, um grave problema de carência de profissionais preparados para facilitar, ou até mesmo possibilitar uma perícia bem feita. Afinal, além de policiais serem notoriamente considerados suspeitos de prejudicar as perícias, essa mesma resolução é contraditória, ao dispor em seu artigo $2^{\circ}$ que "a Superintendência da Polícia Técnico Científica tomando conhecimento, por qualquer meio, dos crimes mencionados no artigo $1^{\circ}$ desta resolução, deslocará, imediatamente, equipe especializada para o local, a qual aguardará a presença da Autoridade Policial ou a requisição desta para o início dos trabalhos”.

É, no mínimo, surpreendente que uma equipe designada pela superintendência da polícia científica não tenha um membro com "autoridade policial" para iniciar seus trabalhos. Tal texto evidenciou, com clareza, que existe falta de profissionais, de formação, ou de ambos. Seja por formação deficitária de peritos, seja por falta de verbas, tal situação é inadmissível em um sistema jurídico moderno, minimamente organizado, e que deveria ser balanceado em sua eficiência e garantismo, em especial, em questões tão fundamentais e intrínsecas ao processo penal.

É reflexo desse grave problema a constatação de que a técnica e sistemática das perícias hoje realizadas são ineficientes. Estima-se que de cada 10 perícias realizadas, 4 a 5 apresentam problemas substanciais (e que, por vezes, as inutilizam) porque a primeira autoridade policial não soube chamar o perito competente, ou apontar suas reais necessidades para a investigação ${ }^{76}$

Posto que, inegavelmente, a perícia é fundamental para a investigação criminal e a produção das provas mais relevantes para o bom andamento processual penal, esse fato,

${ }^{76}$ BENGOCHEA, Jorge Luiz Paz, GUIMARÃES, Luiz Brenner, GOMES, Martin Luiz, ABREU, Sergio Roberto. "A transição de uma Polícia de controle para uma Polícia Cidadã". In: São Paulo em Perspectiva, São Paulo, Fundação Seade, vol. 18, 2004, p. 128. 
por si, justificaria a importância do presente estudo. Afinal, dentro do ordenamento brasileiro, o órgão oficial responsável pela realização de perícias médico legais são as polícias científicas de cada Estado da federação.

\section{b) Organização da Polícia Científica em São Paulo}

Devido à necessária delimitação de tema, e até por existirem poucas diferenças entre as estruturas dos diferentes Estados, os dados se restringirão novamente ao Estado de São Paulo, onde a Polícia Científica, diretamente subordinada à Polícia Civil do Estado, é dividida entre o Instituto de Criminalística e o Instituto Médico Legal. Por abordar o presente estudo principalmente as perícias médico legais, e de competência do Instituto Médico Legal, este último será mais detidamente analisado.

O Instituto Médico Legal do Estado de São Paulo foi fundado oficialmente em 1885, à época como "Serviço Médico Policial da Capital". Ele era composto por apenas dois médicos, com regulamento estabelecido no ano de 1886, sendo o órgão técnico mais antigo da polícia científica que se tem registro ${ }^{77}$.

Em 1892, o então presidente do Estado (corresponderia hoje ao governador), Bernardino de Campos, publicou um decreto que alterou as atribuições da polícia, cabendo à perícia médico legal também o atendimento clínico a detentos.

Já, em 1924, o número de médicos legistas do Estado, passou de 4 para 8, indicando forte aumento da demanda. Cinco anos depois, o governo elaborou um novo projeto, que reformulou as competências e estrutura do serviço, e reorganizou o então "Serviço Médico-Legal".

Nessa época, foi criado o "Conselho Médico-Legal", com intuito de fornecer bases técnicas em Medicina Legal para julgamento de causas criminais (que, no presente estudo, será a atribuição mais relevante dentre aquelas realizadas por peritos médicos). Ficaram então reunidos no mesmo órgão o "Gabinete Médico-Legal”, os laboratórios de toxicologia e de anatomia patológica e microscopia e os postos médicos legais do interior.

No ano de 1958, o então “Gabinete Médico-Legal” mudou para o atual edifício da sede do Instituto Médico Legal, especialmente construído para tal fim. Um ano depois, o

77 GOVERNO DO ESTADO DE SÃO PAULO. Secretaria de Segurança Pública. Histórico do Instituto Médico Legal. São Paulo, 2013. $\quad$ Disponível em <http://www.polcientifica.sp.gov.br/institucional_IML_historico.asp >. Acessado em 12 jan. 2012. 
serviço como um todo adotou a denominação atual.

Embora a mais conhecida das funções do Instituto Médico Legal seja a necropsia (popularmente chamada de autópsia), esse tipo de exame hoje constitui apenas $30 \%$ do movimento do Instituto Médico Legal ${ }^{78}$. A maior parte do atendimento, portanto, é oferecida a indivíduos vivos, pessoas que foram vítimas de acidentes de trânsito, agressões, acidentes de trabalho, entre outros.

Entre as competências e obrigações do Instituto Médico Legal atualmente está a função de desenvolver pesquisas no campo da Medicina Legal, visando o aperfeiçoamento de técnicas e criação de novos métodos de trabalho embasados no desenvolvimento tecnológico e científico. Cabe também ao Instituo Médico Legal promover os estudos e a respectiva divulgação de trabalhos técnicos e científicos relativos às áreas da Medicina Legal ${ }^{79}$.

Com relação às análises de competência do Instituto Médico Legal, em indivíduos vivos estão realizar exames de lesão corporal, sexologia, sanidade física, verificação de idade, constatação de embriaguez e exames radiológicos para elucidação de diagnósticos dos legistas. Também é de competência do Instituto Médico Legal a realização de exames e pesquisas em produtos tóxicos, em líquidos orgânicos, vísceras, alimentos e outras substâncias, ainda que os últimos, por vezes, possam ser realizados também pelo Instituto de Criminalística, conforme o caso.

Por sua vez, com relação aos cadáveres, cabe ao Instituto Médico Legal a realização de exames necroscópicos, exumações, exames da área de antropologia e similares. Também é de sua competência efetuar perícias em material biológico de vítimas, elaborar trabalhos fotográficos de pessoas, peças e instrumentos relacionados com as perícias, bem como realizar perícias e pesquisas no campo da odontologia legal.

Embora essa função não seja de conhecimento do público em geral, também compete ao Instituto Médico Legal realizar avaliações psicológicas das vítimas para conclusão de perícias e prestar assistência social aos familiares e vítimas. Por fim, como função genérica, compete ao Instituto Médico Legal emitir laudos técnicos periciais

78 GOVERNO DO ESTADO DE SÃO PAULO. Secretaria de Segurança Pública. Histórico do Instituto

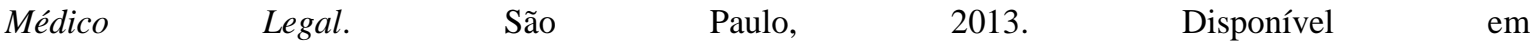
<http://www.polcientifica.sp.gov.br/institucional_IML_historico.asp >. Acessado em 12 jan. 2012.

${ }^{79}$ GOVERNO DO ESTADO DE SÃO PAULO. Secretaria de Segurança Pública. Descritivo funcional do Instituto Médico Legal. São $\quad$ Paulo, $2013 . \quad$ Disponível <http://www.polcientifica.sp.gov.br/institucional_IML_descritivo.asp >. Acessado em 12 jan. 2012. 
pertinentes à sua área de atuação, observada a legislação em vigor ${ }^{80}$.

Nitidamente, tais atribuições exigem um número de profissionais elevado, e em sua maioria qualificados. Como em outras áreas, a administração pública tem dificuldades no preenchimento dessas lacunas, e precisa dar uma resposta à demanda existente. Nesse processo, surgem mecanismos de improviso, que por vezes não funcionam como deveriam ou se esperava.

\section{c) Soluções adotadas para o excesso de demanda e seus riscos}

O Estado de São Paulo, há décadas em franco crescimento, sofre pelo excesso de demanda em diversos tipos de serviços fundamentais. Com relação ao Instituto Médico Legal este problema se aplica e, como em muitos outros serviços, soluções para dar maior vazão à demanda represada foram estudadas ao longo dos anos.

Uma das soluções postas em prática foram as delegações às prefeituras para realização de exames simplificados em cadáveres, em especial, em casos em que o exame do Instituto Médico Legal não fosse obrigatório (ainda que, por vezes, necessário). Essa descentralização, visivelmente contrária a qualquer busca por excelência do serviço, ocorreu, por exemplo, na capital e em diversas outras cidades do Estado de São Paulo.

Grande parte da população, de forma recorrente, se confunde na diferenciação entre os trabalhos do Instituto Médico Legal e os serviços de verificação de óbito (conhecidos pela sigla "SVO"). E essa diferenciação é de fundamental importância e relevância para este estudo.

Os SVO são unidades mantidas pelas prefeituras para simples constatação de óbito e verificação macroscópica, indicando a causa mortis mais provável, sem o rigor e a precisão da necropsia. Afinal, esta, ao contrário dos SVO, lança mão da anatomia patológica e outros recursos de Medicina Legal, tais como as dosagens toxicológicas, entre outros.

A função dos SVO, portanto, não é de realizar perícias completas, muito menos complexas. Em detrimento da precisão, consistem em uma forma mais célere de

${ }^{80}$ GOVERnO DO ESTAdO DE SÃO PAULO. Secretaria de Segurança Pública. Resolução SSP-05/2013. São Paulo, Diário Oficial - Poder Executivo, 08 jan. 2013. Disponível em <http://www.imesp.com.br/PortalIO/DO/BuscaDO2001Documento_11 4.aspx?link=/2013/executivo\%2520s ecao\%2520i/janeiro/08/pag_0005_AMUH5M4HK8F4Re3H5BVT6K4RT59.pdf\&pagina=5\&data=08/01/20 $13 \&$ caderno=Executivo\%20I\&paginaordenacao=100005 >. Acessado em 12 jan. 2013. 
fornecimento do documento conhecido como "atestado de óbito", necessário ao sepultamento de cadáveres.

Embora os documentos emitidos pelos SVO devam ser assinados por um médico, ele não necessariamente passa pelo exame de um perito legalmente habilitado. No entanto, devido à expressiva quantidade de óbitos e outras ocorrências constatadas, por vezes, os SVO acabam, por assim dizer, substituindo o Instituto Médico Legal em casos que, muitas vezes, seriam de competência exclusiva (em tese, de obrigação) do Instituto Médico Legal.

Um exemplo claro dessa asserção é com relação às mortes não esclarecidas, sequer por indícios. Nesses casos, os cadáveres deveriam obrigatoriamente ser periciados. Entretanto, seja por falta de estrutura ou por falta de pessoal qualificado, ou talvez até mesmo por conta de partes interessadas na não realização da perícia, com base na causa mortis apresentada em determinado laudo emitido pelos SVO, uma morte nitidamente não esclarecida é "camuflada" como sendo conhecida, e a perícia, que poderia vir a ser determinante em um caso judicial, não é realizada.

É evidente que existem casos de mortes não esclarecidas em que nem os Institutos Médico Legais nem os SVO realizam qualquer tipo de exame ou necropsia. Nesses casos, em regra, a família recorre ao atestado de óbito expedido por um médico particular que, evitando maiores sofrimentos diante da perda, o expede indicando a causa mortis mais provável. Entretanto, se não o fizer com o rigor necessário e apenas nos casos em que a lei assim permite, esse profissional pode ser punido nas esferas penais e dos tribunais de ética da classe previstos em lei. No entanto, não carece maior destaque esta modalidade de averiguação de causa mortis, vez que é pontual, e o foco do presente estudo não é discutir atos isolados de médicos, mas sim o sistema em que as perícias médico legais estão inseridas como um todo.

\section{d) Situação atual do Estado de São Paulo}

O Estado de São Paulo possui atualmente uma população de cerca de 42 milhões de habitantes ${ }^{81}$. Com atendimentos anuais de cerca de 1,5 milhão de requisições,

\footnotetext{
${ }^{81}$ Segundo dados da Fundação Sistema Estadual de Análise de Dados - SEADE, no início de janeiro de 2013 o Estado de São Paulo possuía uma população estimada de 42.135 .412 habitantes. Disponível em <www.seade.gov.br>. Acessado em 02 jan. 2013.
} 
expedição de mais de 1 milhão de laudos, e exame de mais de 3 milhões de peças ${ }^{82}$, a polícia científica do Estado de São Paulo é a maior da América Latina, e pode ser considerada uma das maiores do mundo.

Por sua vez, no ano de 2010, por exemplo, foram realizadas mais de 480 mil perícias em todo o Estado de São Paulo. Estatisticamente, esses números revelam que, por ano, são realizados pouco mais de um atendimento para cada 100 habitantes.

Considerando que hoje no Estado existem cerca de 600 peritos médicos em atividade $^{83}$, existe um volume médio de aproximadamente 800 atendimentos anuais por perito, ou cerca de 66 atendimentos mensais. Para conseguir atender a essa enorme demanda, o Instituto Médico Legal conta com uma estrutura complexa, mas que ainda assim, conforme demonstram os números acima, por vezes, revela-se insuficiente. Compõem essa estrutura órgãos centrais, localizados na capital, e outros organizados por regiões, denominadas Equipes de Perícias Médico Legais ("EPML”) que abrangem praticamente todo o Estado ${ }^{84}$.

Na Capital, estão localizados os dois prédios centrais do Instituto Médico Legal, que estão equipados e capacitados para realizar todos os exames de competência do Instituto, e que acabam por servir de referência para a população em geral, mais especificamente a unidade Clínicas e a unidade Butantã, que concentram, também, a maior parte da estrutura administrativa do Instituto.

Além das duas unidades centrais, a capital conta ainda com 7 Equipes de Perícias Médico Legais, espalhadas pelas regiões da cidade. Somam-se a essas, na Grande São Paulo, outras 9 Equipes, totalizando, apenas na região metropolitana da Capital, 18 instalações do Instituto Médico Legal.

O interior e o litoral do Estado encontram-se subdivididos em 11 macrorregiões, cada qual com um número diferente de Equipes de Perícias Médico Legais, de acordo com a demanda, conforme segue: Araçatuba (3 equipes), Araraquara (3 equipes), Bauru (3 equipes), Campinas ( 9 equipes), Marília (4 equipes), Presidente Prudente (4 equipes), Ribeirão Preto (5 equipes), Santos (4 equipes), São José dos Campos (5 equipes), São José do Rio Preto (6 equipes) e Sorocaba (5 equipes). Somando-se capital e interior,

${ }^{82}$ GOVERNO DO ESTADO DE SÃO PAULO. Superintendência da Polícia Técnico-Científica. Solicitados concursos para médico legista e perito criminal. São Paulo, 2011. Disponível em $<$ http://www.polcientifica.sp.gov.br/_noticias.asp?CODIGO=223〉. Acessado em 12 jan. 2012.

${ }^{83}$ Informações fornecidas por telefone pela aassessoria de imprensa do Instituto Médico Legal em 11 de julho de 2011.

${ }^{84}$ GOVERNO DO ESTADO DE SÃO PAULO. Secretaria de Segurança Pública. Unidades do Instituto Médico Legal. São Paulo, 2013. Disponível em 〈http://www.polcientifica.sp.gov.br/IML unidade0.asp $>$. Acessado em 12 jan. 2012. 
chega-se a um número total de 67 Equipes de Perícias Médico Legais espalhadas pelo Estado, além dos dois prédios Centrais.

Embora conte com essa estrutura complexa, o próprio Estado de São Paulo reconhece suas carências. Inegáveis diante do frequentemente relatado sucateamento das instalações do Instituto Médico Legal ${ }^{85}$, que causam indignação. Em entrevista recente, o próprio superintendente da polícia científica do Estado de São Paulo revelou recentemente que, há mais de 25 anos, o quadro de servidores do Instituto de Criminalística e do Instituto Médico Legal não é preenchido adequadamente ${ }^{86}$. Obviamente, o reconhecimento é um avanço. Entretanto, essa não é a única carência.

Em meio a esse cenário, o superintendente da Polícia Técnico Científica do Estado de São Paulo, Celso Perioli, declarou que "o desejo da Polícia Científica de São Paulo de se aproximar do padrão de qualidade das perícias do seriado norte-americano 'CSI' é evidente". Na mesma oportunidade, concluiu que o governo tem "procurado adquirir ferramentas que agilizem alguns procedimentos, mas nunca podemos esquecer que essa ferramenta precisa de um profissional treinado para a operar".

Entretanto, referido "padrão de qualidade", ficcional, está longe da realidade, até mesmo no ordenamento estadunidense, onde a série televisiva mencionada se baseia. Ao mesmo tempo, o que se almeja, neste estudo, não é cobrar a adoção dos avanços técnicos aclamados nas obras de ficção científica. Mas, sim, aperfeiçoar os instrumentos à disposição, utilizando, para isso, a convergência entre informações, o emprego apropriado das verbas no setor, melhor qualificação e remuneração dos profissionais, entre tantos outros fatores que, embora dependam também de certo avanço tecnológico, devem passar longe do que no próprio Direito Norte-americano convencionou-se chamar de "junk science" (em tradução livre, "ciência de lixo").

Nesse sentido, adiante, em capítulo específico, serão apresentados apontamentos de Direito comparado baseados no princípio do Common Law, notadamente do Direito Norte-americano, que em muito difere dos institutos do Civil Law. Ainda que não se pretenda parear os recursos disponíveis, a comparação pode orientar possíveis formas de otimização dos resultados das perícias médico legais no Direito Brasileiro, dentro da atual realidade.

\footnotetext{
${ }^{85}$ FOLHA DA MANHÃ S.A.. IMLs de SP têm instalações precárias, cheiro podre e falta de técnicos. 2013. Disponível em <http://www1.folha.uol.com.br/cotidiano/1210727-imls-de-sp-tem-instalacoes-precariascheiro-podre-e-falta-de-tecnicos.shtml >. Acessado em 06 jan. 2013.

${ }^{86}$ GOVERNO DO ESTADO DE SÃO PAULO. Superintendência da Polícia Técnico-Científica. Solicitados concursos para médico legista e perito criminal. São Paulo, 2011. Disponível em

<http://www.polcientifica.sp.gov.br/_noticias.asp?CODIGO=223 >. Acessado em 12 jan. 2012.
} 


\section{e) Intervenções do Governo estadual e da Assembleia Legislativa}

O governo do Estado de São Paulo, mesmo ciente dos problemas, conforme anteriormente exposto, não divulgou, nos últimos anos, nenhuma reestruturação dos serviços oferecidos pelo Instituto Médico Legal, ou qualquer plano de ação para sua otimização. As ações que foram verificadas pela administração basicamente se resumiram à autorização de concursos públicos, que, em sua maioria, foram para mera reposição de profissionais, além de inauguração de instalações em macrorregiões que apresentavam excesso de demanda e, consequentemente, demora acima da média do sistema, como, por exemplo, em Araraquara ${ }^{87}$.

Cabe mencionar ainda que a parceria com o Instituto de Pesquisas Tecnológicas IPT tem rendido bons frutos no sentido de aplicar técnicas mais modernas às perícias. Também têm sido estabelecidos alguns poucos vínculos com universidades no intuito de modernizar técnicas, mas os resultados averiguados até o presente momento são incipientes e não permitem constatar qualquer avanço significativo.

Uma das ações que possivelmente traria resultados mais significativos seria a educação continuada dos peritos. Afinal, o concurso público já é um bom selecionador de candidatos à carreira, que ainda têm seus conhecimentos complementados pelo curso de formação na Academia Nacional de Polícia - ANP. Embora tenha um currículo diversificado, em especial, nas áreas da criminalística e do Direito, além da preparação policial em si (tiro, defesa policial, entre outros), não contempla muitas das inovações tecnológicas que já existem, de forma maciça, em diversos locais do mundo, que também não são requisitadas em nenhuma das etapas, seja do concurso, seja da formação do perito, e que possivelmente poderiam ser ministradas por convênios ou parcerias mais consistentes com universidades de ponta.

Entretanto, cabe ressaltar que o governo do Estado não é o único responsável pela estagnação na evolução dos trabalhos da Polícia Científica, vez que os trabalhos do legislativo impactam profundamente no estabelecimento do atual quadro das perícias médico legais, por diversos fatores inerentes às funções da própria Assembleia Legislativa. Afinal, é o legislativo estadual que define as bases da lei de diretrizes

87 GOVERNO DO ESTADO DE SÃO PAULO. Superintendência da Polícia Técnico-Científica. Inauguração do novo prédio do IC/IML em Araraquara. São Paulo, 2011. Disponível em <http://www.polcientifica.sp.gov.br/_noticias.asp?codigo=283 >. Acessado em 12 jan. 2012. 
orçamentárias, e que destina os recursos para os diferentes setores da atividade estatal, como, por exemplo, o Instituto Médico Legal.

Nesse sentido, procedeu-se a um levantamento de proposições formalizadas na Assembleia Legislativa do Estado de São Paulo (“ALESP”), referentes ao Instituto Médico Legal, ou a perícias médico legais em geral. Inicialmente foi analisado um período de 10 anos, entre o mês de junho do ano de 2001, e o mês de junho do ano de 2011. Posteriormente, foram analisados apenas os projetos de lei em tramitação nos últimos 18 meses, ou seja, entre julho de 2011 a janeiro de 2013, como se demonstrará adiante.

No período inicial de 10 anos analisados, foram formalizadas pelos deputados estaduais do Estado de São Paulo 283 proposições referentes ao tema ${ }^{88}$. Como delimitação de escopo, este trabalho analisou mais detidamente as proposições formalizadas, desde janeiro de 2008 até junho de 2011, vez que a grande maioria das proposições anteriores a essa data ou já perderam objeto ou têm remotas chances de ir à pauta de votação.

Verificou-se que, nesse período de 42 meses analisado, foram formalizadas 87 proposições acerca do tema, dos quais aproximadamente 63\% (equivalente a 55 proposições) referem-se a propostas de emendas orçamentárias, recomendando a alocação de recursos para unidades do Instituto Médico Legal.

Entretanto, notou-se que os deputados em tais proposições não apresentaram laudos técnicos sobre as reais necessidades das unidades às quais solicitavam recursos, mas sim levaram à pauta do dia reivindicações de suas respectivas regiões, e normalmente em "pacotes", solicitando, juntamente com o pleito por aumento de verbas para as equipes de perícia médico legal ou de suas instalações, pedidos correlatos, tais quais delegacias, postos de saúde, rabecões, entre outros.

Em segundo lugar no total de proposições analisadas, com aproximadamente $22 \%$ dessas (ou 19 no total), estão as indicações ao Governador do Estado para provimento de novas instalações ou de reformas e melhorias em instalações do Instituto Médico Legal. Percebe-se, novamente, que têm a mesma finalidade das emendas ao orçamento, qual seja, a melhoria do serviço em determinado local, de forma dispersa.

Somando-se as emendas orçamentárias e seus pedidos de aumentos de repasses com as indicações de instalações específicas, juntas elas representam $85 \%$ do total de

\footnotetext{
${ }^{88}$ Pesquisa realizada na base de proposições legislativas da Assembleia Legislativa do Estado de São Paulo, utilizando os argumentos "IML", "Instituto Médico Legal", "perícia médico legal" e "médico legal".
} 
proposições no período relacionadas à perícia médica no Estado. Em números absolutos, foram 74 solicitações por verbas para a área nesse período, portanto.

Já entre os $15 \%$ restantes, aproximadamente $4 \%$ (ou 3 proposições em números absolutos) referem-se a requerimentos de informações a unidades específicas do Instituto Médico Legal, para averiguar eventuais irregularidades. Por fim, apenas os demais 11\% referem-se a projetos de lei ou pareceres sobre os respectivos projetos.

Do total de 6 projetos de lei verificados no período mencionado, 3 deles (ou seja, a metade), tinham por escopo mudar o nome de instalações do Instituto Médico Legal, o que obviamente nada representa para a melhoria dos serviços. Ao final, portanto, apenas 3 projetos de lei, que, de alguma forma, eram relacionados às perícias médico legais visavam alguma mudança legislativa real no período.

Desses três projetos, o menos impactante, dentro do escopo deste trabalho (Projeto de Lei ALESP 474/2009) prevê desconto no Imposto sobre a Propriedade de Veículos Automotores - IPVA, para pessoas que não incorrerem em infrações de trânsito. A relação desse projeto com o Instituto Médico Legal é que, por meio do benefício, pretende-se diminuir as ocorrências de trânsito e, com isso, diminuir o volume de perícias realizadas. As discussões do projeto preveem, ainda, um aumento no repasse das verbas aos hospitais que atendiam traumatizados de trânsito, bem como ao Instituto Médico Legal, como forma de compensar o déficit atualmente existente entre capacidade e demanda. O projeto foi convertido no Projeto de Lei ALESP 497 de 2010, tendo recebido parecer favorável da Comissão de Constituição e Justiça e da Comissão de Finanças, Orçamento e Planejamento, e tendo recebido parecer desfavorável apenas da Comissão de Transportes e Comunicações, o que não é suficiente para sua retirada da pauta da casa. Desde março de 2012, esse projeto está pronto para a ordem do dia, aguardando inclusão na pauta para votação pelos deputados em plenário.

O segundo (Projeto de Lei ALESP 758/2009), e não muito mais impactante, prevê que o transporte funerário intermunicipal, bem como o fornecimento de urnas e caixões mortuários, deverão apenas ser realizados por empresas concessionárias ou permissionárias do município em que ocorrer o óbito, ou no município em que se der o sepultamento. Um dos objetivos do projeto é uniformizar a prática dos Serviços de Verificação de Óbito - SVO. Este projeto está aprovado pela Comissão de Comissão e Justiça e pela Comissão de Assuntos Municipais. Desde abril de 2010, o projeto está pronto para a ordem do dia, aguardando sua inclusão na pauta para votação pelos deputados em plenário. 
Já o projeto de lei analisado nesse período inicial mais relevante e impactante no objeto deste estudo, e que foi votado e convertido Lei Complementar $n^{\circ} 1064$, de 13 de novembro de 2008, foi o Projeto de Lei Complementar ALESP 60/2008 ${ }^{89}$, que aprovou a reestruturação das carreiras policiais civis, do quadro da secretaria de segurança pública. Essa lei, além de atualizar, ainda que de forma discreta, o salário de peritos e demais técnicos de perícia médico legal, também previu o aumento no número de servidores estaduais. Entretanto, conforme mencionado anteriormente, mesmo após essa reestruturação, o superintendente da Polícia Científica reconhece que o quadro não está plenamente preenchido.

Já no segundo período abordado por este estudo, compreendido entre julho de 2011 a janeiro de 2013, e que objetivou apenas analisar os projetos de lei e projetos de lei complementar mais recentes, cujo objeto é o Instituto Médico Legal, foram encontrados 6 projetos de lei utilizando a mesma metodologia de pesquisa ${ }^{90}$. De imediato, o número se mostra surpreendente, uma vez que, no período compreendido pelos últimos 18 meses, foram encontrados 5 projetos, ante os 6 projetos do período compreendido pelos 10 anos anteriores, o que equivale ao aumento da média de projetos por ano em mais de $500 \%$, saltando de 0,6 para 3,33 projetos anuais.

O primeiro desses projetos (Projeto de Lei ALESP 798/2011) propõe instituir um programa de atendimento multidisciplinar a crianças e adolescentes vítimas de crimes sexuais, mediante ações coordenadas das áreas de segurança pública, saúde e de assistência social. Embora referido projeto não discuta propriamente a estrutura do Instituto Médico Legal, aborda um tema relevante para a sociedade, e coloca o referido Instituto como uma das instituições autorizadas a atender as vítimas fragilizadas, e o insere em um programa multidisciplinar.

Possivelmente, as perícias voltadas para esse tipo de crime terão evolução com a aprovação do programa, com chances de representar um avanço significativo nas técnicas utilizadas nas perícias nessa área. Atualmente, o projeto encontra-se em análise na Comissão de Constituição Justiça e Redação, na Comissão de Defesa dos Direitos da Pessoa Humana e na Comissão de Finanças Orçamento e Planejamento.

O segundo projeto verificado (Projeto de Lei ALESP 23/2012) é mais um daqueles

${ }^{89}$ GOVERNO DO ESTADO DE SÃO PAULO. Lei Complementar n ${ }^{\circ}$ 1064, de 13 de novembro de 2008. São Paulo, Diário Oficial - Poder Executivo, 14 nov. 2008, pp. 1, 3 e 4.

${ }^{90}$ Novamente foi realizada pesquisa na base de proposições legislativas da Assembleia Legislativa do Estado de São Paulo, utilizando os argumentos "IML", "Instituto Médico Legal”, "perícia médico legal” e "médico legal”, no período compreendido entre 01 jul. 2011 e 13 jan. 2013. 
que em nada contribuem, vez que apenas sugerem homenagens por meio de alterações de nomes, nesse caso de uma rodovia. O terceiro, por sua vez (Projeto de Lei ALESP 38/2012), objetiva instituir a Coordenadoria de Engenharia de Segurança do Trabalho no Estado de São Paulo. Uma vez que a única influência desse projeto no Instituto Médico Legal seria a possível redução do número de perícias em médio a longo prazo, a exemplo do projeto anterior, não será realizada uma análise detalhada a respeito do seu conteúdo.

O quarto projeto desse período mais recente (Projeto de Lei ALESP 483/2012) almeja disciplinar o serviço de transporte intermunicipal de cadáveres. A sua justificativa está na necessidade de nova regulamentação de empresas que realizam transporte de cadáveres, adequando questões referentes a preservação deles, bem como o respeito aos familiares na abordagem por essas empresas. Embora não seja diretamente relacionado ao Instituto Médico Legal, a discussão do projeto, bem como a apresentação de emendas, podem evoluir e contribuir às técnicas de conservação atualmente adotadas nas unidades do Instituto Médico Legal, e até mesmo no andamento e prazo para realização de perícias, quando requisitadas. Atualmente, encontra-se em análise na Comissão de Constituição Justiça e Redação e na Comissão de Saúde.

O quinto e último projeto verificado no período (Projeto de Lei ALESP 749/2012) visa a criação do cargo de Odontolegista no Estado de São Paulo. Esse profissional seria apto a realizar perícias antropológicas e odontolegais, mediante o desempenho de funções específicas e que requerem a expertise de um profissional habilitado, tais como realizar exame em local de encontro de ossada e de exercício ilegal de odontologia, realizar exames antropológicos em ossadas com possibilidade de determinação de causa mortis, cronotanatognose, sexo, grupo étnico, idade e estatura; proceder à diferenciação entre restos humanos e animais; proceder à identificação odontolegal e antropológica para a determinação da identidade de indivíduos ignorados, carbonizados, esqueletizados, macerados, saponificados, putrefeitos, espostejados e outras situações em que a identificação pela face ou pela papiloscopia esteja prejudicada; realizar exame em marcas de mordida em objetos e alimentos, em cadáveres ou no vivo; determinar a idade no vivo por meio das características odontológicas ou das radiografias carpais, no caso de menor com idade não comprovada; proceder à diferenciação entre perdas dentárias em vida (recente ou antiga) e pós morte; avaliar o dano corporal oriundo de procedimento clínico odontológico; e realizar exumação com finalidade de determinação de identidade ou constatação de suposto erro odontológico.

Destaca a justificativa do projeto que o campo de atuação do odontolegista abrange 
desde perícias em foro administrativo, criminal, cível até a identificação humana, sendo seu papel na identificação de extrema importância em casos de acidentes de massa, destacando-se o desastre aéreo que, por sua dimensão, resulta em cadáveres carbonizados, fragmentados e, muitas vezes, em estado avançado de decomposição. Obviamente, em circunstâncias extremas como a citada, o método de comparação odontológica torna-se imprescindível, possibilitando uma perícia mais eficaz e rápida diante da necessidade de grande quantidade de identificações em um curto espaço de tempo.

Atualmente, no Estado de São Paulo, as perícias odontológicas são realizadas por médicos legistas que, apesar do esforço e competência, não são odontolegistas, mas exercem tal função no chamado "Núcleo odonto legal” do Instituto Médico Legal. Fora a falta de formação específica na área, esses médicos poderiam contribuir, de forma mais eficaz e valiosa, em outros tipos de perícias, otimizando o atendimento como um todo.

Dessa forma, é possível concluir que a criação do cargo de odontolegista no Instituto Médico Legal poderia facilitar o trabalho sempre que houver a necessidade de reconhecimento de ossadas, e principalmente em casos onde, devido ao número de vítimas ou seu estado, é difícil o reconhecimento pelo médico legista, mas existe a possibilidade de identificação pelos meios utilizados pelo odontolegista.

É de se reconhecer, portanto, a importância desse projeto como um meio possível de evolução no trabalho da perícia médico legal no Estado de São Paulo. Difícil, no entanto, é entender o motivo de esse cargo ainda não existir, o que demonstra certa incapacidade do Estado na evolução das perícias, em especial na adoção de novas técnicas, ou ainda de técnicas mais eficazes, em detrimento dos protocolos que há anos são adotados.

Esse projeto foi publicado em dezembro de 2012. Atualmente aguarda tramitação para ser encaminhado às comissões que forem definidas nas sessões de discussão do projeto na Assembleia.

Conforme se depreende deste capítulo, as proposições do legislativo que versam sobre a perícia médico legal são escassas e, muitas delas, quando não inúteis, a exemplo das constantes homenagens e trocas de nome de prédios e obras, tendem a ser paliativas, e não atacam o problema de frente. Entretanto, o aumento das proposições, notadamente dos projetos de lei, no último ano e meio, entre os mais de onze anos analisados, podem indicar uma evolução nesse sentido.

Um dos objetivos deste estudo é, justamente, fomentar a busca por soluções mais 
definitivas, que possam eventualmente ser desenhadas em forma de projetos de lei, ou ainda de ações objetivas do executivo. O que, em uma análise não pessimista, parece ser viável, passando apenas por obstáculos como vontade política, e reconhecimento das defasagens que atualmente existem, mas não apenas no discurso. 


\section{VI - A ATUAL VINCULAÇÃO DOS INSTITUTOS MÉDICO LEGAIS E A PROPOSTA DE AUTONOMIA}

Na maioria dos Estados, os Institutos Médico Legais estão vinculados aos órgãos de Segurança Pública. Por exemplo, no Estado de São Paulo, o Instituto Médico Legal, junto com o Instituto de Criminalística, compõe a Polícia Técnico-Científica, subordinada diretamente à Secretaria de Segurança Pública do Estado.

Em outros Estados, porém, houve uma desvinculação da área de segurança, como no Estado do Amapá, onde a Coordenadora de Perícias tem status de secretaria de Estado; o Rio Grande do Sul, que vinculou o Instituto Médico Legal à Secretaria de Estado de Justiça, Trabalho e Cidadania, e o Pará, que criou uma estrutura independente do Instituto Médico Legal e do Instituto de Criminalística, vinculado diretamente ao governo do Estado. Entretanto, na maior parte das vezes os Institutos Médico Legais estão vinculados à polícia dos Estados.

Existe hoje um movimento entre juristas, legistas e professores de Medicina Legal que é favorável à desvinculação da perícia médica, para que ela atue de forma autônoma. Esse movimento é apoiado pela Sociedade Brasileira de Medicina Legal, pela Associação Brasileira de Criminalística, por boa parte das Seccionais da Ordem dos Advogados do Brasil, além de outras associações civis e entidades ligadas aos Direitos Humanos.

Ainda sob a sombra dos anos de chumbo, época tenebrosa da perícia no Brasil, a exemplo do que ocorreu em outras partes do mundo, tais movimentos buscam afastar a imagem dos Institutos Médico Legais da figura policialesca de outros tempos. Não que hoje em dia exista algum tipo de coação na confecção de laudos, ou ainda que sejam praticadas torturas e congêneres, de forma indiscriminada, ou não combatidas. Entretanto, a desvinculação poderia representar uma fase de grande evolução da perícia no Brasil, além de afastar um incômodo sentimento de suspeição que ainda impera em parte da população.

Tal desvinculação, inclusive, já era parte do Primeiro Programa Nacional de Direitos Humanos, criado em $1996^{91}$. Atualmente, o programa está em sua terceira versão, de 2010, sob a coordenação da Secretaria Especial dos Direitos Humanos,

\footnotetext{
${ }^{91}$ Anexo ao Decreto 1.904 de 1996. Disponível em <http://www.planalto.gov.br/ccivil_03/decreto/19501969/anexo/and1904-96.pdf>. Acessado em 13 jan. 2013.
} 
vinculada ao Ministério da Justiça ${ }^{92}$.

Para o presente estudo, porém, cabe discutir se, além de uma questão de Direitos Humanos, essa desvinculação pode ou não representar um avanço na qualidade dos laudos periciais. Afinal, um dos maiores objetivos do presente estudo é buscar formas de otimização do uso de laudos periciais no processo penal, para que eles representem legítimo instrumento de busca da verdade, conforme melhor se discutirá adiante.

Neste sentido, a desvinculação se apresenta como uma inovação que seria muito bem vinda. Não apenas pelo maior grau de isenção dos peritos médico legais ao participarem de uma instituição autônoma, mas também pelo fato de que as verbas destinadas tanto ao Instituto de Criminalística, quanto ao Instituto Médico Legal, não concorreriam com as verbas destinadas à Segurança Pública.

Isto evitaria que em casos de crises, ou ondas de violência decorrentes do combate ao crime organizado como a que o Estado de São Paulo, e em particular a Cidade de São Paulo, atravessou em 2012 (e continua a atravessar, ao menos até a data de depósito desta dissertação), ocasionem redirecionamento de verbas que seriam da perícia para o aumento do efetivo policial. Afinal, em ocasiões como estas, impera o anseio da população e se ignora o planejamento.

Ademais, a formação dos peritos médico legais com a desvinculação poderia ser mais bem direcionada, além de continuada. Afinal, parece lógico que ao exercício da função de um perito é muito mais útil a elaboração de teses e estudos do que participar de academias de polícia. O perito precisa saber por onde uma bala entra, por onde ela sai e qual sua possível trajetória. E, para tanto, o perito não necessariamente precisa saber atirar ou mirar com precisão.

Outro benefício indireto de uma possível desvinculação das perícias da Segurança Pública seria tornar o Instituto de Criminalística e o Instituto Médico Legal mais simpático às universidades. Uma vez que sejam estes institutos destacados de sua imagem policialesca, e se aproximem de uma estrutura eminentemente técnica, certamente terão maior apreço por parte de professores e pesquisadores. A consequencia direta seria uma ampliação dos convênios com as universidades ou, pelo menos, aumentar as chances destes se concretizarem.

Cabe ressaltar que a perícia em outros ordenamentos jurídicos ora é vinculada à segurança pública, ora não tem qualquer vínculo com o Estado, ora tem um regramento

\footnotetext{
${ }^{92}$ BRASIL. Ministério da Justiça. Programa Nacional de Direitos Humanos - 3. Disponível em <http://portal.mj.gov.br/sedh/pndh3/index.html> Acessado em 13 jan. 2013.
} 
autônomo. Entretanto, entende-se neste estudo que o direito comparado pouco pode auxiliar nesta questão, uma vez que os maiores argumentos da desvinculação provém da realidade política, cultural e histórica brasileira.

De qualquer forma, tende este estudo a apoiar a desvinculação ao menos da polícia e, consequentemente das Secretarias de Segurança Pública. Ainda que nos dias atuais o Instituto Médico Legal não abrigue personagens que fazem desfavores à perícia e sua imagem, como Harry Shibata (que hoje, aos 85 anos, ainda é "convidado" para falar sobre os laudos e atestados de óbitos que ele assinava para os militares, "supostamente" falseando assassinatos e torturas que ocorriam durante a ditadura ${ }^{93}$ ), o próprio nome "Polícia Científica" que é dado ao conjunto do Instituto de Criminalística e Instituto Médico Legal no Estado de São Paulo, traz grande desconforto por remeter a esta fase trágica da perícia nos anos de chumbo da Ditadura Militar.

Este motivo, por si, seria suficiente para dar apoio à desvinculação. Aliado às questões orçamentárias e técnicas, mais que uma possibilidade, parece a este estudo que a desvinculação é necessária, e até mesmo urgente.

\footnotetext{
${ }^{93}$ FOLHA DA MANHÃ S.A.. Comissão da Verdade toma depoimento de legista da ditadura. 2013. Disponível em <http://www1.folha.uol.com.br/fsp/poder/50258-comissao-da-verdade-toma-depoimento-delegista-da-ditadura.shtml $>$. Acessado em 16 jan. 2013.
} 


\section{VII - BREVES APONTAMENTOS SOBRE A TEORIA DA PROVA E A PERÍCIA ENQUANTO PROVA}

\section{a) Teoria da prova: conceito, objeto, fontes e meios de prova; instrução e procedimento probatório}

No Direito moderno, em praticamente todos os ordenamentos jurídicos organizados, não são aceitas decisões sem fundamentação e embasamento, que não permitam deixar evidente a motivação do magistrado ao proferir uma sentença, e a justificativa lógica e racional de determinada tese. Isso se faz necessário até por uma questão de controle da isenção e racionalidade do juiz, que deve ficar evidente às partes, e sujeito aos órgãos de controle dos próprios sistemas judiciários.

Por sua vez, o convencimento do juiz se dá por meio das provas apresentadas no processo, e deve ser pautado por critérios lógicos e racionais. Afinal, decisões que sejam inexplicáveis diante das provas apresentadas não são congruentes com as regras processuais atuais em praticamente todo o mundo, regras essas que exigem clareza, transparência e isenção do magistrado, o qual não pode julgar sem um critério lógico, ou baseado em ciências inacessíveis ou ocultismos.

Diante desse fato, a prova científica, tal como hoje conhecemos, possui enorme importância no Direito e, como tal, também tem suas limitações e métodos de controle. Dessa forma, imperioso se faz abordar, no presente estudo, a teoria de prova, para compreender a abrangência e o conceito da perícia enquanto prova científica no processo.

Na linguagem jurídica, a palavra "prova" possui mais de uma acepção, sendo que pode ser utilizada para designar a atividade probatória, ou o resultado que se extrai dessa atividade e, ainda, para designar os meios de prova ${ }^{94}$. De qualquer forma, a prova é peça central do processo, uma vez que em razão dela será o pedido julgado procedente ou não.

Afinal, o fundamento dos pedidos levados a juízo, em regra são fatos, por meio dos quais a parte pretende produzir consequências jurídicas, e que são levados aos autos por meio de afirmações. Entretanto, não basta simplesmente oferecer ao juiz os fatos, mas também deve haver o convencimento sobre a veracidade do ora alegado, de forma que se sustente decisão judicial, posto que a afirmação do juiz necessariamente deve

94 GRINOVER, Ada Pellegrini; SCARANCE FERNANDES, Antonio; GOMES FILHO, Antonio Magalhães. As nulidades no processo penal. $8^{\mathrm{a}}$ ed, São Paulo, Revista dos Tribunais, 2004, p. 141. 
corresponder à verdade, não podendo, assim, pairarem dúvidas sobre os fatos alegados.

Posto que o convencimento do juiz é obtido pela demonstração desses fatos, existe uma intrínseca ligação entre a necessidade de o juiz buscar a verdade, a afirmação dos fatos e a demonstração da afirmação alegada nos fatos ${ }^{95}$.

A prova, porém, é mais que um instrumento de convencimento do juiz a respeito da verdade de fatos alegados. Em seu conceito, a prova possui duas acepções distintas, a lógica e a jurídica. A primeira, a prova lógica, consiste em tudo aquilo que "persuade de uma verdade o espírito", enquanto a segunda, a prova judicial, consiste no meio regulado pela lei para "descobrir e estabelecer, com certeza, a verdade de um fato controvertido" 96

A prova jurídica, ou judicial, se caracteriza como um elemento instrumental, de forma que demonstra os fatos em que baseia a acusação, ou o alegado pelo réu em sua defesa. A prova constitui, assim, o instrumento por meio do qual se forma a convicção do juiz a respeito da ocorrência ou inocorrência de certos fatos ${ }^{97}$.

Dessa forma, para as partes, a prova consiste em um instrumento hábil a influir na convicção do juiz a respeito de suas alegações. Por sua vez, para o juiz, é um instrumento do qual faz uso para averiguar a veracidade dos fatos que fundamentam as alegações das partes.

Não obstante, seja qual for sua conceituação, a prova é algo proveniente da realidade, dos acontecimentos da vida humana, que o Direito compartilha. De forma simplista, a prova é um conceito abrangente, e se destina a qualquer um que pretenda demonstrar a existência de um fato.

Seja ela em um âmbito conjugal, em que uma pessoa tenta provar ao seu parceiro a ocorrência ou não de uma traição; seja em um contexto de relação de trabalho, em que um empregado tenta provar motivos de atraso ou ausência; seja em uma disputa de sócios, em âmbito contencioso ou não, em que um sócio tenta provar um desvio de recursos; seja em uma investigação ou instrução criminal, em que o réu tenta provar sua inocência e a acusação provar sua culpa, cada prova apresenta suas peculiaridades e não difere, ontologicamente, de forma substancial. Obviamente, as provas devem seguir as características e pressupostos de aceitação para o que se pretende prestar, mas o conceito de prova, em si, do ponto de vista deste estudo, é muito mais unitário do que o defendido

95 ALVIM, José Eduardo Carreira. Teoria Geral do Processo. $8^{\mathrm{a}}$ ed, São Paulo, Forense, 2002, p. 252.

${ }^{96}$ ALVIM, José Eduardo Carreira. op. cit, p. 251.

97 GRINOVER, Ada Pellegrini; SCARANCE FERNANDES, Antonio; GOMES FILHO, Antonio Magalhães. op. cit, p. 141. 
por alguns autores e estudiosos do Direito, o que se reconhece e respeita, mas não fará parte de uma análise mais aprofundada nesta oportunidade.

Superada a conceituação da prova, que no âmbito do processo, ao menos, pode ser caracterizada, resumidamente, como um instrumento que traz ao processo elementos para convicção do juiz, passa-se a se discutir sobre quais matérias tais elementos podem estar relacionados, ou, em outras palavras, qual é o objeto da prova, ou o thema probandum. Resumidamente, o objeto da prova, no âmbito judicial, consiste em qualquer coisa, fato, acontecimento, ou circunstância que deva ser demonstrado no processo, mas não apenas fatos e acontecimentos do mundo exterior, mas também aspectos internos da vida psíquica do réu ou indiciado ${ }^{98}$.

No processo penal, ao contrário do processo civil, todos os fatos alegados devem ser comprovados, sejam eles controversos ou não ${ }^{99}$. Tal diferença encontra respaldo no pressuposto de que o processo penal baseia-se em uma verdade real, ao passo que o processo civil contenta-se com uma verdade formal.

Com relação ao objeto, em regra, as provas costumam ser classificadas em diretas ou indiretas, sendo as diretas aquelas que consistem no fato em si, ou que se referem ao fato, conseguindo reproduzi-lo ou representá-lo. Por sua vez, as provas indiretas se referem a outro fato, o qual por analogias ou raciocínio lógico, se possa provar o fato principal. Nessa classificação, entre as provas indiretas, podem ser incluídos os indícios e as presunções.

Conceituado o objeto de prova, faz-se necessário conceituar os meios de prova, bem como as fontes de prova. Fontes de prova podem ser definidas de forma sucinta como pessoas ou coisas das quais se possam extrair informações capazes de comprovar a veracidade de uma alegação ${ }^{100}$.

Por sua vez, os meios de prova distinguem-se das próprias fontes, consistindo em técnicas destinadas à investigação de fatos relevantes para a causa. Diferentemente das fontes, são considerados fenômenos internos do processo e do procedimento, sendo cada um deles "constituído por uma série ordenada de atos integrantes destes", realizados em contraditório, com a observância das formas que a lei estabelece, e dirigidos pelo juiz ${ }^{101}$.

Cabe ressaltar, entretanto, que parte da doutrina não distingue fontes e meios de

\footnotetext{
${ }^{98}$ MARQUES, José Frederico. FERRARI, Eduardo Reali, DEZEM, Guilherme Madeira (Atual.). Elementos do Direito Processual Penal. Vol. 2, $3^{\text {a }}$ Ed. Campinas, Millenium, 2009.

99 ARANHA, Adalberto José Q. T. Camargo. Da Prova no Processo Penal. $7^{\text {a }}$ Ed. São Paulo, Saraiva, 2006.

${ }^{100}$ DINAMARCO, Cândido Rangel. A Instrumentalidade do Processo. $6^{\mathrm{a}}$ ed. São Paulo, Malheiros, 1998, p. 86.

${ }^{101}$ DINAMARCO, Cândido Rangel. op. cit., p. 87.
} 
prova, sob a alegação que os meios de prova são as fontes probantes, os meios pelos quais o juiz recebe os elementos ou motivos de prova. Nesse sentido, motivos de prova seriam as alegações que "determinam, imediatamente ou não, a convicção do juiz" 102 .

Com relação às fases do procedimento probatório, o Código de Processo Penal em vigor, que é o que mais importa ao presente estudo, não disciplina uma fase prévia ou específica de ordenamento das provas a serem produzidas. A primeira fase do procedimento probatório, entretanto, é a da proposição.

Nessa fase, os atos cabem primordialmente às partes, que têm interesse de oferecer as melhores condições e fornecer o material probatório mais completo e relevante ao juiz. Em outras palavras, almejam, em regra, as partes que suas alegações sejam tidas como verdadeiras, motivo que as torna as principais envolvidas nesta fase ${ }^{103}$.

Em resumo, a proposição consiste na indicação dos fatos que devem ser provados, bem como dos meios probatórios para isso utilizáveis. No processo penal, portanto, a proposição, ou o momento de proposição da prova, consiste uma fase de ônus para o réu, onde são elencadas as "armas" a serem utilizadas contra ele.

Uma vez proposta a prova, esta pode ser admitida ou não pelo juiz, que tem a faculdade de indeferi-la, com seu juízo de relevância, quando a considerar manifestamente protelatória ou inútil. Destaque-se, entretanto, que pelo princípio do contraditório as partes têm direito de acesso à prova, sendo qualquer restrição é motivo para se alegar cerceamento de defesa ou de acusação ${ }^{104}$.

Em sequência, assim que a prova é admitida, ela deve ser produzida, o que consiste na reprodução, no processo, dos fatos afirmados pelas partes. Em outras palavras, a produção é o ato pelo qual se averiguam, pelos meios probatórios, os fatos afirmados pelas partes. A realização da prova, portanto, significa "medidas consistentes em extrair das fontes os elementos de convicção procurados" 105.

Constata-se, desta feita, que a produção de provas se dá em momentos distintos, e que podem variar conforme se der sua exteriorização. Em regra, as provas de natureza oral (depoimentos pessoais, testemunhas, esclarecimentos de peritos) são produzidas em audiência, enquanto a prova pericial deve ser produzida antes da audiência e, por sua vez,

\footnotetext{
${ }^{102}$ ALVIM, José Eduardo Carreira. op. cit, p. 270.

${ }^{103}$ ALVIM, José Eduardo Carreira. op. cit, p. 271.

104 GRINOVER, Ada Pellegrini; SCARANCE FERNANDES, Antonio; GOMES FILHO, Antonio Magalhães. op. cit, p. 143.

${ }^{105}$ DINAMARCO, Cândido Rangel. op. cit., p. 91.
} 
as provas documentais se produzem no momento em que são admitidas ${ }^{106}$.

No caso específico da perícia, no processo penal, esta em algumas circunstâncias, pode ser realizada após as audiências, como, por exemplo, a diligência complementar. Seria mais adequado afirmar que a perícia tem produção paralela ou sucessiva à produção de provas orais na instrução probatória, conforme as peculiaridades de cada caso. Mas, em regra, a perícia é determinada no início do processo e, normalmente até antes deçe, ainda na fase do inquérito policial.

\section{b) A perícia enquanto prova: natureza, procedimento e valoração probatória}

Indubitavelmente, hoje, a perícia constitui um meio de prova dos mais conhecidos, e que recebe tratamento legal específico na grande maioria dos ordenamentos jurídicos atuais. Sendo assim, a prova pericial é considerada típica, e que representa um dos principais marcos do direito probatório. Essa notoriedade é respaldada pela existência dos conhecimentos técnicos específicos que só o perito ou experto possui, e que deu novos rumos à prova no processo penal.

Em regra, e resumidamente, a perícia é requisitada quando o fato não é suscetível de ser provado por declarações, seja de partes ou de testemunhas, ou, ainda, por documentos. Conforme mencionado no capítulo deste estudo que discorreu sobre o histórico da perícia, quando ocorre o exame direto da coisa pelo juiz, tal procedimento é conhecido por inspeção judicial, exame judicial, acesso judicial ou reconhecimento judicial. Ocorre que, frequentemente, tal exame não é possível, principalmente em virtude da carência de conhecimentos técnicos específicos por parte do juiz.

Em virtude dessa carência, afinal, por mais culto que possa ser um julgador é humanamente impossível que tenha conhecimentos aprofundados em todas as áreas da ciência. Em especial, a partir da era moderna, surge a necessidade de se recorrer a uma pessoa experiente, que tenha notórios conhecimentos em sua área de atuação, e que possa transmitir ao julgador suas observações. Esse observador qualificado, que nada mais é senão uma pessoa entendida ou técnica na matéria em discussão, denominou-se perito (ou experto). E o processo de verificação dos fatos pelos peritos é o que se chama perícia, conforme já discorrido anteriormente.

É possível, assim, definir a perícia como a prova destinada a levar à luz do juiz

\footnotetext{
${ }^{106}$ ALVIM, José Eduardo Carreira. op. cit, p. 271.
} 
elementos instrutórios sobre fatos e normas técnicas que dependam de conhecimento específico. A perícia, por sua vez, torna-se mandatória quando houver a inaptidão do juiz para verificar ou apreciar determinados fatos, sob o risco de prejudicar a decisão de uma lide.

Em regra, a doutrina costuma distinguir dois tipos de perito, de acordo com a utilidade da perícia. Embora sempre o perito realize verificações a respeito de matéria em que tem expertise, sua função ora é de emitir uma declaração de ciência, ora é de afirmar um juízo. Assim, o perito pode somente verificar, como também pode, após a verificação, emitir juízos de valor ${ }^{107}$.

Conforme já previamente mencionado, considera-se que a perícia é um meio de prova, conforme o tratamento dispensado à perícia no ordenamento jurídico brasileiro. Nessa acepção, a perícia pode ser considerada uma prova pessoal, consistindo as manifestações do perito em afirmações conscientes, e voltadas a fazer fé do pronunciado, assumindo-se, então, o perito como o sujeito da prova.

Não fosse a perícia considerada um meio de prova, mas de avaliação de prova, poder-se-ia afirmar que a prova em questão, ora analisada pelo perito, é real e material, pois o objeto de suas considerações não se apresentaria como afirmação consciente e destinada a fazer fé de sua verdade.

Tal acepção não parece prevalecer, uma vez que o Código de Processo Penal inclui a perícia no capítulo referente à prova, cuja escolha corresponde, no entendimento majoritário, na concepção da perícia como um meio de prova. Entretanto, parte da doutrina entende que a perícia não seria propriamente um meio de prova, mas algo à parte, com natureza intermediária entre a prova e a sentença ${ }^{108}$.

Todavia, no ordenamento atual, toda prova é instrumental, consistindo em ato instrutório da convicção do juiz sobre os fatos alegados, e que fornece embasamento à sentença. Não fosse assim, as provas pessoais não teriam condição de prova, passando a serem meios de reconhecimento de prova. Entretanto, as pessoas, sejam testemunhas ou peritos, atestam sua percepção das coisas. Considera-se então a perícia, a exemplo de outros testemunhos, uma prova pessoal.

Nesse sentido, e conforme melhor se detalhará adiante, é interessante notar que, em países cuja tradição jurídica tem raízes no Common Law, o perito recebe o mesmo tratamento dado a uma testemunha que possui conhecimentos específicos, o que

\footnotetext{
${ }^{107}$ MARQUES, José Frederico. FERRARI, Eduardo Reali, DEZEM, Guilherme Madeira (Atual.). op. cit. ${ }^{108}$ ARANHA, Adalberto José Q. T. Camargo. op. cit.
} 
configura a figura do expert witness, já anteriormente mencionado. É certo que a figura do perito se distingue da testemunha comum, a ordinary witness, que tem por função declarar apenas sobre o que viu, mas não deixa de realizar o perito uma espécie de testemunho.

Alguns doutrinadores, como Claus Roxin, definiram o perito como uma pessoa que não se confunde com a testemunha, tampouco com o juiz ${ }^{109}$. Nessa acepção, a perícia não teria natureza testemunhal por diversas razões. A principal delas é que o perito atua por encargo do tribunal, enquanto a testemunha é escolhida por ter conexão com os fatos, relatando o que aconteceu no passado. Além disso, o perito só atua quando se faz necessário um conhecimento especial, o que também o afasta da figura do colaborador para a inspeção ocular. Por fim, o perito é, em regra, substituível, exceto se não existir a possibilidade de, na prática, nomear outra pessoa com semelhante conhecimento.

É abordado ainda por Roxin o conceito de testemunha-perito (expert witness), que, a rigor, não é um perito, mas sim uma testemunha, posto que este de fato não está sujeito ao tribunal. São, portanto, pessoas que informam sobre fatos passados, sendo que para que fizessem essa observação lhes era necessário ter conhecimento específico sobre o assunto.

Na mesma esteira, distingue o perito do juiz, posto que o perito deve estar limitado às suas funções auxiliares, não podendo constatar e avaliar fatos, exceto nas circunstâncias de perícia. Além disso, o tribunal tem controle sobre o resultado da perícia, apreciando sua força persuasiva, mas podendo afastar-se das conclusões do laudo, sendo o perito apenas um "assistente" do tribunal ${ }^{110}$.

Retomando os procedimentos e as características da prova pericial na lei processual penal brasileira, que é o principal enfoque deste estudo, o Código de Processo Penal em vigor, em seu Artigo 158, preceitua que é indispensável a realização da perícia quando a infração deixar vestígios, sendo, portanto, uma prova legalmente imposta, sob pena de nulidade insanável ${ }^{111}$. Esta é a hipótese mais primária de realização da perícia, mas outras perícias podem ser regularmente realizadas, como diligências complementares, averiguações sobre sanidade mental, entre outras.

Ademais, o próprio artigo mencionado destaca a possibilidade de a perícia ser

\footnotetext{
${ }^{109}$ ROXIN, Claus. CÓRDOBA, Gabriela E.; PASTOR, Daniel R (Trad.). Derecho Procesal Penal. Buenos Aires, Editores del Puerto, 2000, p. 240.

${ }^{110}$ ROXIN, Claus. CÓRDOBA, Gabriela E.; PASTOR, Daniel R (Trad.). op. cit., p. 239.

111 GRINOVER, Ada Pellegrini; SCARANCE FERNANDES, Antonio; GOMES FILHO, Antonio Magalhães. op. cit, p. 177.
} 
direta ou indireta, sendo a direta aquela realizada sobre o próprio corpo de delito, ou objeto, enquanto a indireta deve apenas ser realizada se houver o perecimento ou desaparecimento do corpo de delito, sendo suprido pela prova testemunhal ou documental. Em outras palavras, a perícia ou exame indireto consiste em "um raciocínio dedutivo sobre um fato retratado por testemunhos" ${ }^{112}$, e aplicável apenas por não se ter a possibilidade do uso da perícia ou exame direto.

No que tange ao perito, o Artigo 159 do Código de Processo Penal em vigor preceitua que, ordinariamente, as perícias são realizadas por peritos oficiais, em outras palavras, pessoas com conhecimentos técnicos vinculados à administração pública ou à justiça. Dessa forma, em regra, o exame deve ser requisitado pelo juiz ou pela autoridade policial diretamente ao diretor da repartição a que pertençam os peritos (na maioria dos casos o Instituto de Criminalística e o Instituto Médico Legal), juntando-se aos autos o laudo assinado pelos peritos oficiais assim que concluída a perícia.

Os peritos também podem, excepcionalmente, serem não oficiais, nomeados $a d$ hoc pelo juiz competente. Entretanto, em matéria penal, isso ocorre apenas em hipóteses excepcionais, como, por exemplo, caso não existam peritos oficiais na localidade dos fatos. Nesses casos, devem ser escolhidas duas pessoas idôneas, portadoras de diploma de curso superior e com habilitação técnica referente à matéria do exame. Todos os peritos não oficiais devem prestar compromisso de desempenhar bem e fielmente seu encargo ao serem nomeados (o que é dispensado aos peritos oficiais).

Em todos os casos, a iniciativa da perícia será sempre da autoridade policial ou do juiz, conforme esteja em curso inquérito policial ou processo judicial. A autoridade poderá agir ex officio ou por provocação, tendo em vista que a prova é um direito das partes, e, sempre que admissível, é vedado à autoridade a sua recusa.

A realização da perícia deve ser precedida dos quesitos formulados pela autoridade, e eventualmente pelas partes e seus assistentes técnicos (quando aplicável), quesitos esses que devem ser respondidos pelo perito. Os quesitos das partes permitem um contraditório mais efetivo, consagrando na prática o direito das partes de se defenderem por meio de provas. Também podem atender à frequente realidade de que as partes conhecem fatos ignorados pela autoridade, que se tornarão objeto da perícia, beneficiando a descoberta da verdade.

As perícias em fase de inquérito policial podem ser realizadas sem a presença do

${ }^{112}$ ARANHA, Adalberto José Q. T. Camargo. op. cit. 
indiciado. Nesses casos, o contraditório é restrito ao processo, momento em que o réu poderá ou impugnar a perícia, ou solicitar novo exame, ou ainda requerer esclarecimentos ao perito. Entretanto, as hipóteses de contraditório restrito (ou diferido) devem ser usadas com parcimônia, vez que representam manifesta ofensa às garantias fundamentais do processo ${ }^{113}$, e jamais se deve partir da premissa de que o investigado é culpado, uma vez que o que se busca por meio da perícia é apenas a verdade dos fatos.

O resultado da perícia será materializado por um laudo, que conterá um relato histórico, com os atos a que o perito procedeu, além da resposta aos quesitos, bem como suas conclusões. As respostas devem ser fundamentadas, indicando as razões pelas quais as conclusões apresentadas são reais, tornando possível o a avaliação de tais conclusões pelo juiz ${ }^{114}$. Com relação ao prazo, o laudo pericial, conforme preceituado no Artigo 160 do Código de Processo Penal em vigor, deve ser elaborado e apresentado no máximo em 10 dias, podendo ser prorrogado por requerimento dos peritos, em casos excepcionais e justificáveis.

Com relação à valoração probatória da perícia, o Código de Processo Penal em vigor, em seu Artigo 182, preceitua que o juiz não está restrito às conclusões do laudo pericial. Esse posicionamento é claro no ordenamento jurídico brasileiro e é consonante ao seu sistema de valoração da prova, de livre convencimento, desde que motivado. A inclusão dessa regra, inclusive, seria dispensável, uma vez que todo o ordenamento jurídico brasileiro está pautado pelo princípio do livre convencimento do juiz.

Em que pese à falta de vinculação do laudo pericial, na prática é evidente que os juízes não têm por hábito ignorar o laudo elaborado pelo perito. Em regra, o juiz toma a prova técnico científica como base de sua fundamentação, até por, na maior parte dos casos, não ser dotado de conhecimentos técnicos especializados ${ }^{115}$. Afinal, a justificação da perícia é justamente inaptidão do juiz para conhecer e avaliar determinados fatos que exigem um conhecimento especial. Assim, se o juiz desprezar a opinião do perito, acabará por não reconhecer a própria necessidade de realização daquela determinada perícia. Dessa forma, o julgador só poderia rejeitar totalmente a perícia em casos de erro ou dolo comprovado.

Não obstante, esse sistema de livre convencimento permite que os laudos periciais

113 GRINOVER, Ada Pellegrini; SCARANCE FERNANDES, Antonio; GOMES FILHO, Antonio Magalhães. op. cit, p. 182.

${ }^{114}$ ARANHA, Adalberto José Q. T. Camargo. op. cit.

115 GRINOVER, Ada Pellegrini; SCARANCE FERNANDES, Antonio; GOMES FILHO, Antonio Magalhães. op. cit, p. 173. 
confeccionados por expertos não compromissados em juízo e juntados pelas partes, conhecidos por laudos extrajudiciais, e que na teoria configuram meros pareceres técnicos, podem ser privilegiados na valoração das provas pelo juiz, mesmo que em detrimento do laudo oficial. É evidente que não pode o magistrado desprezar as provas obtidas na instrução do processo, mas eventualmente esses laudos extrajudiciais podem mudar o convencimento do juiz em relação a determinados fatos do processo.

Resta, portanto, descrita a perícia enquanto prova no ordenamento brasileiro, incluindo sua natureza, procedimento e valoração probatória. Ter em foco esses aspectos é fundamental para que possam ser estudados institutos de ordenamentos jurídicos estrangeiros como possíveis auxiliares na otimização da utilização dos laudos periciais no ordenamento jurídico brasileiro. 


\section{VIII - POSSÍVEIS CONTRIBUIÇÕES ADVINDAS DE ORDENAMENTOS JURÍDICOS ESTRANGEIROS À PERÍCIA NO BRASIL}

Analisadas as origens e a história da perícia, a forma que o ordenamento jurídico brasileiro regulamenta a perícia, bem como os desafios que a realidade brasileira apresenta à boa utilização dos laudos periciais, um recurso que pode auxiliar a discussão no sentido de oferecer possíveis novas diretrizes ao modelo de perícia adotado no Brasil atualmente é o Direito comparado. Afinal, o próprio breve histórico da perícia narrado alhures deixa evidente que a perícia mudou, e muito, ao longo dos anos, o que deu margem inclusive a diferentes tratamentos, em diferentes ordenamentos jurídicos modernos, sem que, no entanto, precisem ou possam ser apontados modelos e práticas certas ou erradas.

Nesse sentido, o presente estudo analisou brevemente o tratamento dado à perícia em alguns ordenamentos jurídicos estrangeiros que pudessem contribuir com a discussão da perícia no ordenamento jurídico brasileiro. A delimitação a esses ordenamentos ocorreu por diferentes motivações, conforme se exporá.

Considerando as raízes históricas do Direito Brasileiro, bem como as possíveis contribuições às perícias em nosso ordenamento jurídico, foi analisado em conjunto, e de forma sucinta, o tratamento dado às perícias em três países da Europa continental que, além de serem provavelmente os povos que mais influenciaram os costumes em território nacional desde o início da colonização do Brasil, tiveram relevância na formação das bases do ordenamento jurídico brasileiro. Dessa forma, esta análise incluiu Portugal, por constituir possivelmente a principal fonte do Direito Brasileiro nesse campo; a Itália, por motivo semelhante, mas também por trazer um tratamento diferenciado ao que equivaleria aos "assistentes técnicos" do Direito Brasileiro; e a Espanha, por oferecer um contraponto aos dois primeiros dentro de uma mesma tradição e raiz histórica do Direito, mas que tem por vertente marcante a oralidade em determinadas fases de seu processo.

Por sua vez, considerando a geopolítica regional, o outro sistema jurídico analisado, ainda que também de forma não exaustiva, foi o do Chile. Este oferece um verdadeiro contraponto regional a todos os sistemas jurídicos da América Latina, em especial, devido ao fato de possuir a mais jovem constituição da região, e uma legislação penal moderna, criada à luz das inovações de diversos ordenamentos jurídicos da 
atualidade. Por esse motivo, mostrou ter relevância ao presente estudo, podendo ser um exemplo a ser trilhado para as evoluções do Direito Brasileiro.

Por fim, em virtude de ser o maior expoente do Common Law, que, como já relatado neste estudo, difere em diversos aspectos dos ordenamentos jurídicos que têm raízes na Civil Law, em especial, no que se refere às perícias, revelou-se relevante o estudo do ordenamento jurídico dos Estados Unidos da América. Afinal, o Direito baseado em precedentes oferece maior flexibilidade às inovações, e em especial no campo da perícia, indubitavelmente o ordenamento jurídico norte-americano foi o que mais densamente debateu as novidades tecnológicas, a aceitação de novas técnicas, bem como as regras que devem orientar tais inovações.

Antes, porém, de passar ao Direito comparado, serão retomadas, em linhas gerais, as possibilidades de aceitação de inovações no ordenamento jurídico brasileiro, observações são imprescindíveis para que possam ser aproveitados os ensinamentos trazidos pelos sistemas jurídicos estrangeiros.

\section{a) Possibilidade de aceitação de inovações no ordenamento jurídico brasileiro com relação à prova pericial à luz dos déficits constatados}

Conforme anteriormente discutido, no Brasil, a legislação até confere poderes ao juiz para discordar das conclusões do perito, consoante o disposto no Código de Processo Penal em vigor, em seu Artigo 182. Todavia, na prática essa possibilidade se mostra praticamente impossível, em especial, em virtude de o perito oficial, ou até mesmo o perito nomeado ad hoc, não ter o confronto de nenhum outro experto minimamente pareado em armas com eles.

Agrava essa situação a baixa qualidade de parte dos laudos, que tem origem na sua excessiva demanda, devido ao reconhecido déficit no número de profissionais (ao menos no Estado de São Paulo, conforme anteriormente exposto); aliada à formação deficitária de parte de peritos, notadamente, em virtude da ausência de um programa de educação continuada. Essa situação resulta na elaboração de laudos não padronizados, por vezes pouco claros, repletos de expressões e palavras vazias e, por vezes, compostos por meras observações, não apoiadas em parâmetros científicos, que, ao final, comprometem substancialmente as conclusões dos magistrados.

Não tem por objetivo o presente estudo demonstrar empiricamente a ocorrência e a recorrência dos textos dúbios e até mesmo ininteligíveis dos laudos periciais. Entretanto, 
ao longo da pesquisa que embasou o presente estudo, foi recorrente o contato com assistentes médicos de partes, conselheiros de Conselhos Regionais de Medicina (notadamente do Estado de São Paulo), advogados atuantes na área criminal, e até mesmo peritos oficiais, que raramente se mostraram surpresos com essas afirmações, quando não relatavam casos absurdos que não poderiam aqui ser relatados, ora por questões éticas, ora devido à imposição do segredo de justiça.

Percebe-se, portanto, que a vinculação da grande maioria dos peritos com órgãos oficiais do Estado, sem nenhum outro experto para contestar seu trabalho em paridade de armas, é por vezes atentatório ao contraditório. Afinal, por serem assemelhados a atos administrativos, expedidos por autoridades estatais, os laudos periciais no ordenamento jurídico brasileiro possuem uma controversa presunção de legitimidade e veracidade, quando, por vezes, são substanciados em conhecimentos científicos obsoletos, incompletos ou duvidosos.

É evidente que seria imprudente sugerir a introdução de um instrumento jurídico ou modelo de prática estrangeira, em qualquer ordenamento jurídico, que não esteja preparado para tanto, ou que seja incompatível com ele. Entretanto, principalmente em uma realidade de mundo globalizada, uma postura de isolamento às inovações de ordenamentos jurídicos estrangeiros é, não apenas, maléfica, como, de certa forma, inviável $^{116}$.

Uma vez reunidas todas as informações pertinentes de um modelo estrangeiro que triunfe em seu país de origem, e verificada a possibilidade de implementação de conceitos inteiros ou parciais em um ordenamento em que a mesma finalidade que o modelo estrangeiro visa não seja atingida, é plenamente possível adaptar evoluções nas regras de qualquer ordenamento jurídico moderno minimamente organizado. E esse conceito se pretende utilizar no presente estudo, em especial com relação à otimização dos resultados dos trabalhos periciais no Brasil.

Identificada parte dos problemas da realidade brasileira atual acerca da sistemática da prova pericial e destacada a pertinência das lições do Direito comparado a essa discussão, abaixo passa a se estudar e analisar alguns ordenamentos jurídicos estrangeiros, delimitados conforme explicitado no início deste item. Frise-se, mais uma vez, que o objetivo não é exaurir as características desses ordenamentos, mas sim identificar pontos que podem contribuir com a otimização e evolução das práticas

\footnotetext{
${ }^{116}$ MOREIRA, José Carlos Barbosa. In: "Notas sobre alguns aspectos do processo (civil e penal) nos países anglo- saxônicos". In: Temas de Direito Processual. $7^{\text {a }}$ série. São Paulo, Saraiva, 2001, p. 157.
} 
adotadas no Brasil.

\section{b) A perícia em países da Europa Central que influenciaram a cultura e o ordenamento jurídico brasileiro: Portugal, Itália e Espanha}

Neste item, conforme anteriormente descrito, se abordará, de forma conjunta, três sistemas jurídicos que tiveram relevância e impacto no ordenamento jurídico brasileiro. Não apenas pelo fato de o Brasil ter raízes históricas, linguísticas e obviamente culturais com estes países, as semelhanças e diferenças entre os ordenamentos jurídicos se revelam relevantes para o presente estudo. Para início da abordagem, resumidamente, passará a se expor o sistema português e, posteriormente, o italiano e o espanhol, para utilizar os contrastes na discussão central do tema.

Em Portugal, a prova pericial vem regrada pelo Código de Processo Penal Português ${ }^{117}$ (adiante neste capítulo denominado pela abreviação “CPPP”), notadamente entre seus artigos 151 e 163. Segundo o artigo 151 do CPPP, "a prova pericial tem lugar quando a percepção ou apreciação dos fatos exigirem especiais conhecimentos técnicos, científicos ou artísticos".

Em Portugal, a perícia é realizada por peritos oficiais, mas na inexistência deles ou na impossibilidade de a realizar caso a caso, tal qual no ordenamento brasileiro, deverão ser nomeados peritos constantes na lista do juízo, ou ainda pessoas de reconhecimento, honorabilidade e competência na matéria em causa.

No mesmo sentido, é da obrigação do perito desempenhar bem a função que lhe for atribuída, podendo aquele que tiver sido nomeado alegar escusa na execução da função, com base na falta de condições indispensáveis para a realização da perícia no caso concreto. Também poderá o perito nomeado ser recusado, em função de iguais motivações, pelo Ministério Público, pelo arguido, pelo assistente, ou pelas partes civis; sem prejuízo da realização da perícia no caso de urgência ou havendo perigo na demora (de forma análoga, senão idêntica, à figura encontrada no ordenamento nacional do periculum in mora).

O perito que não desempenhar corretamente sua função ou não apresentar o relatório pericial no prazo poderá ser substituído pela autoridade judiciária que o tiver nomeado, ou por aquela que eventualmente a substituir. Aos peritos são aplicáveis as

\footnotetext{
${ }^{117}$ PORTUGAL. Assembleia da República. Código de Processo Penal Português. Disponível em <http://www.portolegal.com/CPPen.htm> . Acessado em 13 jan. 2013.
} 
tradicionais regras referentes ao impedimento, além da recusa e escusa, previsões essas expressas no artigo 477 do CPPP.

Cumpre salientar que para a realização da prova pericial é necessário que a autoridade judiciária competente despache o ofício, o contendo, entre outros requisitos, o nome dos peritos e a indicação sumária do objeto da perícia, que pode ser determinada pelo magistrado ou por requerimento da parte interessada.

No CPPP não é vedada a indicação de assistentes técnicos pelas partes, chamados em Portugal de "consultores técnicos". Estes, por sua vez, uma vez indicados, poderão formular quesitos para os peritos, bem como assistir à realização da perícia, propor a efetivação de determinadas diligências, formular observações e objeções aos peritos, não sendo vedado o auxilio aos patronos das partes.

Nesse ponto, cumpre destacar um avanço em comparação ao direito brasileiro. A faculdade expressa de assistir à realização da perícia subentende uma maior integração entre o consultor técnico e o perito oficial, algo que, em princípio, parece ao autor deste estudo que seria bem recepcionado no ordenamento jurídico brasileiro, e que poderia otimizar os laudos periciais.

Ainda, sempre que entender conveniente, a autoridade judiciária poderá formular quesitos aos peritos, enquanto assiste à realização da perícia, tornando-se permitida a presença do arguido e do assistente no momento da realização da perícia se necessário. Nota-se, nesse ponto, uma medida garantista, questionável em alguns ordenamentos, que rechaçam tal possibilidade.

Como resultado final, e por fim, os peritos elaborarão o relatório contendo as respostas aos quesitos que lhes forem formulados e conclusões devidamente fundamentadas. Entretanto, fica a possibilidade de a autoridade judiciária, o arguido, o assistente, as partes civis, bem como aos consultores técnicos, formularem esclarecimentos (quesitos complementares) aos peritos, como de forma analógica também garante o Direito Brasileiro.

Uma questão que cabe destaque, porém, neste casos de forma negativa, é que caso o relatório não possa ser elaborado logo em seguida à realização da perícia, o juiz poderá determinar que seja entregue em 60 dias, podendo, em casos de especial complexidade, prorrogar, a requerimento dos peritos, por mais 30 dias, o que leva o prazo de formalização e entrega do laudo para longos 90 dias. Percebe-se, neste ponto, uma brecha para medidas protelatórias, as quais se pretende condenar por meio deste estudo, em especial, quando se compara tal prazo com o verificado no Direito Brasileiro, que, 
conforme mencionado alhures, é de 10 dias, prorrogável somente por requerimento do perito de forma justificada e comprovada, conforme previsto no Artigo 160 do Código de Processo Penal atualmente em vigor no Brasil.

Por fim, a autoridade judiciária competente poderá autorizar que o relatório seja apresentado até a abertura da audiência, caso o conhecimento dos resultados da perícia não for indispensável para o juiz. Poderá esta também convocar os peritos para prestar esclarecimentos complementares em qualquer fase do processo. Devem, em todos os casos, serem comunicados o dia, a hora e o local em que se efetivará tal diligência, ou, ainda, que seja realizada nova perícia, ou renovada a perícia anterior ao cargo de outros peritos.

Percebe-se que não apenas os aspectos históricos e culturais unem Brasil e Portugal, mas, em especial, no campo jurídico, as densas bases do Civil Law também. O mesmo se aplica à Itália, cujo ordenamento no campo da perícia passará a ser analisado adiante.

Um aspecto característico do ordenamento jurídico italiano é que a perícia é admitida como fonte de prova se utilizada para a extração de dados probatórios ou feitura de valorações, bem como se forem necessárias específicas competência técnicas, científicas ou artísticas, conforme preconizado pelo Artigo 220 do "Codice de Procedura Penale ${ }^{, 118}$, ou o código de processo penal italiano de 1988 (tratado neste item doravante como "CPPI").

Possivelmente em decorrência de traumas advindos da influência de Cesare Lombroso $^{119}$, em outros tempos, são hoje vedadas perícias em pessoas quanto às suas habilidades, profissionalismo e a tendência para delinquir. Também não são permitidas perícias acerca de caráter, de personalidade ou de qualidades psíquicas. Em resumo, há a inibição das investigações por meio de introspecção psicológicas, nelas compreendidas as investigações criminológicas, garantindo assim a liberdade moral e evitando um pré julgamento do cidadão.

Com relação aos "peritos das partes", a legislação italiana institui a assistência técnica, sendo os expertos auxiliares denominados "consulenti tecnici". Tais consultores técnicos são semelhantes aos auxiliares das partes previstos no ordenamento brasileiro,

\footnotetext{
118 ITÁLIA. Codice de Procedura Penale. Disponível em <http://dbase.ipzs.it/cgifree/db2www/notai/arti.mac/SOMMARIO?datagu=10/24/1988\&redaz=088G0492\&swpag=12B > . Acessado em 13 jan. 2013.

${ }^{119}$ ITALIA. Museo Criminologico. Cesare Lombroso the Inventor of Criminal Anthropology. Disponível em <http://www.museocriminologico.it/lombroso_1_uk.htm>. Acessado em 02 jan. 2013.
} 
em especial, para questionarem a perícia já realizada e para formulação de pareceres, conforme preconizado nos Artigos 225 e 233 do CPPI.

Frise-se, nesse sentido, que tanto o Ministério Público, quanto as partes privadas, podem constituir seus "consulenti tecnic" desde a fase investigatória. O mesmo direito, por sua vez, é atribuído à defesa. Isso proporciona, na previsão legal, fundamentação adequada de requerimentos cabíveis na fase de investigações, evitando acusações infundadas e decretos temerários de medidas de cautelares. Este é mais um dispositivo que, à exemplo do mencionado acima com relação ao direito português, poderia ser bem recepcionado no ordenamento jurídico brasileiro.

Já na fase de debates, se não for ordenada a realização de perícia, por não ser requerida ou deferida, as partes podem nomear assistentes para a formulação de valorações técnicas em pareceres, aos quais se atribui determinado valor probatório. Nesse caso é facultada a realização de investigações para buscar provas, sendo prevista a possibilidade de serem ouvidos os expertos na fase de debates sob exame cruzado. Ainda que seja esta uma exceção, tal previsão existe no ordenamento jurídico italiano e guarda certa relação com o direito do Common Law.

Ao se admitir a perícia requerida por uma das partes ou, excepcionalmente, determinada pelo juízo de ofício, o juiz nomeia peritos oficiais (ou outros, se com competência particular para a questão). Se a atividade pericial for complexa ou exigir interdisciplinaridade, o juiz deve nomear mais de um perito constituindo um colegiado de peritos para a garantia de eficiência do resultado.

No decorrer dos trabalhos periciais, instaura-se um, por vezes ferrenho, contraditório entre peritos e assistentes técnicos das partes, que podem apresentar ao juiz requerimentos, observações e reservas. Não é vedado, nesses casos, a participação dos assistentes nas operações periciais, podendo propor investigações específicas. Este é um exemplo de dispositivo que se aproxima do Common Law e que o ordenamento jurídico brasileiro não permite expressamente.

Sobre o controle exercido pelo juiz, o experto pode tomar contato com o material probatório, assistir ao exame das partes ou à produção de provas, e pedir informações ao acusado, ao ofendido e a outras pessoas. Por ser taxativo o rol de permissões, presumemse vedados outros acessos.

É da competência do juiz, também, a elaboração de quesitos aos peritos, bem como garantir a participação das partes, assegurando, assim, a manifestação do perito, das partes e de seus assistentes técnicos. Nitidamente esses dispositivos constituem métodos 
garantistas.

Em geral, os peritos devem responder aos quesitos oralmente, podendo ser concedido prazo para a apresentação das respostas em face à complexidade da questão, o qual pode ser prorrogado mais de uma vez. Caso seja indispensável, pode ser solicitada ao juiz a apresentação de uma manifestação escrita.

Ressalte-se, por fim, que se nomeados depois das realizações das perícias, os assistentes técnicos podem examinar os laudos e requerer autorização judicial para analisar a pessoa, a coisa ou o lugar periciado. Institui-se, então um controle posterior ao da produção da prova nessa hipótese. Também cumpre salientar que os assistentes (ou consultores, dependendo da tradução) e os peritos podem ser submetidos a exame cruzado, caso isso seja relevante para o convencimento do juiz e, consequentemente, ao justo julgamento da lide.

Por sua vez, no ordenamento jurídico espanhol (último a ser analisado nesse item relativo ao alguns ordenamentos jurídicos da Europa continental que influenciaram o Direito Brasileiro), as perícias e os testemunhos no processo penal são realizados no decorrer do juicio oral, cabendo aos peritos responderem as perguntas e dúvidas que a eles forem dirigidas.

As perícias médico legais devem ser realizadas por dois peritos, exceto por consenso das partes em relação a um único experto ${ }^{120}$. Ainda assim, o juiz apenas aceita como oficial o laudo sustentado por um único perito se este for submetido a uma equipe técnica e fizer referência a critérios analíticos.

Diante do desenvolvimento das ciências e de novas tecnologias, vale destacar, alguns dados fornecidos pelos peritos são agregados aos autos como prova documental, dispensando a presença e a contestação daqueles que os formularam. É expresso no ordenamento jurídico espanhol, mais precisamente no Artigo 788, Parágrafo $2^{\circ}$, da "Ley de Enjuciamiento Criminal" espanhola (equivalente ao código de processo penal da Espanha, e tratada neste subitem como "LECE") ${ }^{121}$ que as perícias emitidas por laboratórios oficiais, como as que verificam a quantidade, natureza e pureza de substâncias, por exemplo, possuem caráter de prova documental. Isso permite a dispensa do comparecimento dos expertos para apresentar informes de diversos tipos de perícias, tais como exames de DNA, balísticos, datiloscópicos, nível alcoólico, ou exames de entorpecentes, posto que

${ }^{120}$ PILLADO, Esther González; CANLE, Inés Iglecias. "La prueba pericial en la nueva ley de enjuiciamento civil”. In: Revista Xurídica Galega. № 27, Vigo, Rexurga, 2000, p. 334.

${ }^{121}$ ESPANHA Ley de Enjuciamiento Criminal. Disponível em 〈http://www.fmyv.es/ci/es/Ss/11.pdf>. Acessado em 09 jan. 2013. 
são tratadas como provas pré constituídas a serem introduzidas no processo por meio de prova documental.

Obviamente, existe a preocupação do legislador na LECE quanto à autenticidade do documento, exigindo que a perícia seja realizada seguindo os protocolos científicos legalmente aprovados. Todavia, não se tratou da regulação do meio de investigação ou da forma adequada de trazer esses elementos ao processo.

Sendo constatada a autenticidade do documento, utiliza-se o procedimento da prova documental para juntada de laudos periciais. Os atos realizados antes ou fora do processo não constituem prova, podendo ser incorporados em determinados casos como prova documental. Isso acontece quando trata-se de documento propriamente dito, mas não de depoimento de testemunha, declarações ou análise pericial corporificados em documentos, que não são convertidas em prova documental.

Frise-se, no entanto, que não possuem natureza de prova os atos de investigação na fase sumarial (de cognição), e não repetíveis na fase do juicio oral, como, por exemplo, interpretações telefônicas, diligências de busca e apreensão, e análises clínicas para constatar níveis de álcool. Podem, porém, serem meios de prova "atípicos" introduzidos no ato dos debates orais, no que passam a ser, de certa forma, legalmente admitidos. Não basta, entretanto, a apresentação de documentos que corporifiquem a diligência, é também necessária a declaração dos peritos que os formularam.

Salienta-se, entretanto, que os entendimentos ora apontados não são totalmente pacíficos. Alguns doutrinadores espanhóis alegam que a prova pericial não pode ser transformada em uma prova documental ${ }^{122}$. Para eles, o fato de documentar uma prova pericial não muda a sua natureza jurídica, uma vez que a prova documental não pode ser apreciada pelo Tribunal, pois não foi ratificada na presença judicial nem foi submetida ao contraditório.

\section{c) A perícia em um ordenamento jurídico totalmente reformulado dentro da América Latina: Chile}

O Chile possui a mais jovem Constituição das Américas atualmente. Tão jovem quanto moderna, em especial nas esferas constitucional e penal, o Chile merece um estudo mais detalhado, por ser em diversos aspectos um exemplo a seguir, embora corra

\footnotetext{
${ }^{122}$ PILLADO, Esther González; CANLE, Inés Iglecias. op. cit., pp. 343 e 344.
} 
o risco, ainda, de possuir vários vícios ocultos a serem evitados.

Afinal, o "Codigo de Procedimiento Penal de Chile" de $2000^{123}$ (atual lei processual penal chilena, doravante denominada "CPPC"), que substitui a lei que vigorava desde 1906, veio repleta de inovações, em sua maioria de cunho garantista, sem, no entanto comprometer a eficácia, constituindo todo um novo jeito de ver o processo penal do Civil Law, em especial o contexto latino-americano.

Com relação às perícias, especialmente as médico legais, desse ordenamento, hoje, no Chile, o Ministério Público e os intervenientes poderão apresentar laudos elaborados por peritos de sua confiança, bem como solicitar na audiência de preparação o juízo oral, para que os expertos sejam citados para declarar e discorrer, em juízo, sobre as conclusões da perícia.

As perícias poderão ser elaboradas e apresentadas durante a fase de investigação ou durante a preparação para o juízo oral. No decorrer dessas etapas os intervenientes poderão solicitar ao juiz de garantia (tradução livre para "juez de garantía”) que dite as instruções necessárias para que os peritos possam examinar os objetos, documentos ou lugares onde irão realizar a perícia. Vale destacar que o juez de garantía é uma figura típica e inovadora do CPPC, e visa não contaminar o magistrado que decidirá a lide em julgamento final.

$\mathrm{Na}$ fase de investigação ou de preparação, as partes podem indicar peritos aos juízes de garantia, que, por sua vez, irão analisar se os peritos possuem seriedade, profissionalismo e competência suficientes para realizar a perícia. Esse juiz também possui o poder de limitar o número de peritos.

Os honorários do perito serão pagos pela parte que indiciar a necessidade da perícia, salvo quando se tratar de parte impossibilitada de custear o trabalho. O último instituto, por exemplo, guarda relação com o direito brasileiro, e é visto pelo presente estudo como positivo, já que é uma garantia de amplo acesso à justiça, e demonstra que nem tudo precisa ser inovado ou renovado, mas apenas as lacunas e as questões que, na prática, demonstram falhas.

No juízo oral, os peritos serão chamados para explicar a conclusão de suas perícias, as técnicas utilizadas, entre outros, devendo reproduzir oralmente sua pesquisa e conclusões. Sendo assim, a prova pericial consiste no informe de peritos, já que está constituída pela declaração pessoal do perito, em juízo, sobre o conteúdo do laudo

${ }^{123}$ CHILE. Codigo de Procedimiento Penal de Chile. Atualizado até a "Ley 19.678". Disponível em <http://www.nuestroabogado.cl/codpropenalsinref.htm>. Acessado em 09 jan. 2013. 
pericial elaborado por ele.

Frise-se que, além das conclusões, o laudo deverá conter a descrição da pessoa ou coisa, objeto de análise, a relação circunstanciada de todas as operações praticadas e o resultado; uma medida tipicamente garantista, e que não compromete a eficácia do sistema.

Desssa forma, os peritos podem ser descritos no ordenamento chileno como auxiliares dos juízes que, ainda de forma implícita, não possuem conhecimento técnicos exigidos para melhor compreender os fatos. Sendo assim, não poderão ser feitas perguntas que inabilitem o perito, pois somente estão autorizadas as perguntas orientadas a determinar a imparcialidade e a idoneidade, assim como referente ao rigor técnico ou científico de suas conclusões.

Ao contrário do que se constata no ordenamento norte-americano, os peritos chilenos não podem ser considerados testemunhas, posto que seus depoimentos devem se resumir somente ao conteúdo de suas perícias. Vale ressaltar que quando um perito for chamado para esclarecer os fatos e não a perícia realizada, será, nesse caso, considerado testemunha, e poderá ser arguido diretamente pelas partes. O perito será considerado um "perito testemunha" quando este for ouvido, estando sujeito às regras da prova testemunhal. Mostra a legislação chilena mais um avanço, no sentido de que flexibiliza ao mesmo tempo regulamenta, dando maior segurança em situações que, no ordenamento brasileiro, poderiam, facilmente, acarretar nulidades.

Quando, no entanto, for tratar de questões essencialmente técnicas ou cientificas sobre os fatos, deve o perito prestar esclarecimento das informações em juízo, de acordo com as regras existentes sobre o informe pericial. Estas regras passam não apenas por códigos éticos, mas também por sanções previstas em lei.

Deve-se ressaltar, no entanto, que, sempre que o experto puder extrair informações sobre a perícia, bem como sobre os fatos, ele reunirá as qualidades de um perito e testemunha. Nesse caso, a oitiva deverá respeitar as regras de informações de perito, quando a ele forem feitas perguntas especificas da sua perícia, respeitando também as regras da prova testemunhal, quando as perguntas se referirem aos fatos.

Como se percebe, a prova pericial chilena traz diversos avanços, que indubitavelmente, poderiam ser traduzidos em evoluções e avanços no ordenamento jurídico brasileiro. Ainda que uma reforma brasileira não viesse a ser tão radical como a chilena, eventuais inovações que, a exemplo do Chile, ampliassem o contraditório, com o necessário garantismo que o processo penal demanda, e sem perda de eficiência, seriam 
algo a que poucos se oporiam.

\section{d) Os precedentes como forma de discussão acerca da aceitação de provas periciais: Estados Unidos da América}

Este estudo, obviamente, possui algumas delimitações, embora nem todas estejam explícitas. Obviamente não se abordará, nem exaurirá, todo o sistema probatório estadunidense. Inicialmente, serão realizados apontamentos sobre a prova pericial no Direito Norte-americano, descrevendo a figura do "expert witness" (que, conforme mencionado alhures, consiste em uma espécie de testemunho de experto, ou perito). Após, serão analisados alguns precedentes (tradução livre para precedents), que possuem no Common Law força análoga à de lei.

Saliente-se que serão utilizados neste estudo termos nativos do Direito Norteamericano. Isso será necessário posto que a maior parte não tem tradução adequada ao vocabulário jurídico comumente utilizado no Brasil.

Assim, indubitavelmente, e conforme anteriormente já mencionado, a prova pericial no Direito Norte-americano difere, e muito, do Direito Brasileiro. A primeira e fundamental diferença é que o perito, ou expert, não é nomeado pelo juiz, mas sim apontado pelas partes e, mais ainda, é ouvido como testemunha, oralmente, e não por meio de laudo técnico apresentado e analisado pelo jury ou judge $e^{124}$ (jurados ou juízo, em tradução livre).

Nesse sentido, e conforme se verá adiante, o expert pode se utilizar de vários recursos tecnológicos durante os trials (julgamentos, porém com as peculiaridades do Common Law). No entanto, a forma de apresentação deve ser oral, e não por escrito, exceto em casos excepcionais, e de forma bem limitada (e, em regra, pela da leitura dodocumento por um terceiro).

Vale ressaltar que de acordo com alguns comentaristas ${ }^{125}$, o Código de Processo Civil em vigor no Brasil teria importado do sistema da Common Law, uma vez que o seu Artigo 421, Parágrafo $2^{\circ}$, introduziu a possibilidade de perícia por declarações orais. Entretanto, tal inovação não prosperou e entrou em desuso.

Assim,, a figura do perito tal qual temos no Brasil é drasticamente diferente

\footnotetext{
${ }^{124}$ ESTADOS UNIDOS DA AMÉRICA. Federal Rules of Criminal Procedure. Atualizado até 01 dez. 2012. Disponível em: 〈http://www.law.cornell.edu/rules/frcrmp >. Acessado em 14 jan. 2013.

${ }^{125}$ MADURO, Flávio Mirza. Prova Pericia: Em busca de um novo paradigma. Rio de Janeiro, Faculdade Gama Filho, 2007, p. 122.
} 
daquela encontrada no Direito Norte-americano. A figura que mais se aproxima do expert witness em nosso Direito é a do "assistente técnico", uma vez que o expert witness também é nomeado pela parte e, pretensamente, para atuar em sua defesa.

Isso, obviamente, pode, até certo ponto, tirar parte da credibilidade dos "laudos" ou conclusões apresentada pelos experts. Como tentativa de amenizar possíveis "desvios" de conduta dos experts, o Direito Norte-americano proibiu que a remuneração dos experts provenha das contingent fees (que seriam análogas às "custas processuais" do direito brasileiro). Todavia, tal restrição apenas "ameniza" o problema, e desperta a preocupação dos comentadores do direito a esse respeito.

Outro aspecto curioso a respeito ao testemunho dos experts reside no fato de que, apesar de eles serem nomeados por uma das partes, teoricamente em sua defesa, conforme mencionado alhures, durante a cross examination (em tradução livre, exame cruzado) nos trials, o representante da outra parte pode inquirir o expert como qualquer outra testemunha.

Essa inquirição transforma, muitas vezes, os trials em verdadeiros jogos de estratégia, o que é típico do adversarial system (ou sistema de confronto), e, por vezes, a parte que nomeou um expert pode ver seu "perito testemunha" depor contra a própria parte que o arrolou.

Ainda mais distante do ordenamento jurídico brasilero foi o rumo dado pelos precedents à aceitação das provas dos experts. Esse assunto, densamente debatido no ordenamento jurídico dos Estados Unidos, merece ser bem detalhado, por se tratar de uma possível contribuição ao Direito Brasileiro, o que se fará adiante.

Acerca da regulamentação sobre a aceitação das provas dos experts nos trials, e a sua própria nomeação, o principal dispositivo se encontra exatamente nas Federal Rules of Evidence ${ }^{126}$, mais especificamente na Rule 706. Nota-se, nesse ponto, que embora os precedentes sejam relevantes no Common Law, além da constituição, outros conjuntos de leis são adotados, como as Federal Rules.

Prosseguindo com o debate, a Rule 706 traz algumas previsões pouco coerentes. Embora a prática tenha consagrado a nomeação dos experts pelas partes, a Rule 706 incluiu uma previsão de que, caso assim entenda necessário, o próprio judge pode

\footnotetext{
${ }^{126}$ ESTADOS UNIDOS DA AMÉRICA. Federal Rules of Criminal Procedure. Atualizado até 01 dez. 2012. Disponível em: <http://www.law.cornell.edu/rules/fre/>. Acessado em 14 jan. 2013.
} 
convocar um expert para arguí-lo, e não apenas as partes ${ }^{127}$. Nesse sentido, até pela suspeição levantada por um expert que comparece a juízo por ato de uma das partes, alguns doutrinadores do Common Law defendem uma aproximação da conduta norte americana à Civil Law, em busca justamente de uma maior isenção nos laudos periciais. Essa posição, como destacado em alguns pontos deste estudo, parece ignorar os problemas advindos da adoção dos peritos oficiais do Estado, conforme já densamente exposto.

Outra disposição da Rule 706, que é bastante significante para a compreensão do papel do expert no processo norte-americano, é a não limitação de quantidade de indicação de experts pelas partes ${ }^{128}$. Esse dispositivo é fundamental na diferenciação deste para outros ordenamentos.

Porém, a provavelmente mais discutível previsão da Rule 706 que "esconde-se" na própria regra é a previsão de que o judge pode definir se aceita ou não a prova do expert para levá-la ao jury ${ }^{129}$. Tal "polêmica" reside numa relação conflituosa entre o entendimento da doutrina (e consagrado nos precedents), de que o judge deve ser passivo em relação ao convencimento do jury, bem como deve se afastar das provas para evitar sua "contaminação"; e, assim, a possibilidade de uma prova ter seu mérito avaliado exclusivamente pelo judge, posto que este não deveria, em tese, ter o "poder" de, discricionariamente, sequer apresentar uma prova ao jury.

Obviamente, por trás dessa contradição exposta existe uma motivação. A principal delas é o que ficou conhecido como "junk science" (que, conforme mencionado alhures, pode ser traduzido como "ciência de lixo"). Com o advento de técnicas mais modernas, oriundas do avanço da ciência, as cortes americanas observaram um fenômeno um tanto indesejável nas expert witnesses. Por várias vezes, observou-se, na corte, que o depoimento do expert era totalmente irrelevante, desconexo com o caso, ou até mesmo sem sustentação científica. Isso acaba por influenciar, em alguns casos, negativamente o jury, que podia ficar confuso diante de tanta informação (por vezes de baixa qualidade).

Diante disso (conforme se verá nos casos práticos adiante mencionados), viu-se uma necessidade crescente de impor algumas regras à admissibilidade do "material" a ser levado pelo experto ao jury.

De forma resumida, as perguntas que começaram a ser aplicadas previamente pelo

${ }^{127}$ Alínea (a) da Rule 706, que dispõe também sobre a possibilidade de a parte contrária arguir a testemunha da outra parte durante a cross examination.

${ }^{128}$ Alínea $(d)$ da Rule 706.

${ }^{129}$ Alínea $(c)$ da Rule 706. 
judge eram: i) "A prova do expert possui alguma utilidade para auxiliar os jurados em sua decisão?”; e ii) “O experto está qualificado para discorrer sobre esta matéria/assunto?".

Portanto, no intuito de "blindar" o jury de influência de "más" evidências acabou por se dar um poder que talvez fosse indesejável ao jury, que é a de avaliar previamente as provas. E, no mérito, valorar os conteúdos a serem pronunciados pelos experts.

Essa função é consagrada no Direito Norte-americano e foi denominada de gatekeeping function (que em livre tradução pode ser entendido como um "segurança de portaria") com relação à possibilidade de levar ou não provas ao jury. Distinção relevante, que deflagra várias reflexões no Direito comparado, sendo a principal dela a necessidade de um poder de controle pelo juiz, mesmo em um ordenamento, por assim dizer, mais permissivo com relação às provas e seus meio de obtenção.

Por fim, outra distinção que ficou consagrada no Direito Norte-americano é a diferença entre o expert e o skilled expert. Nesse ponto, novamente, o Direito Norteamericano difere consideravelmente do brasileiro. No passado apenas eram aceitos como experts membros de comunidades científicas e acadêmicos com notório conhecimento. A partir de casos que requeriam não apenas ciência, mas muito mais conhecimentos técnicos ou práticos, abriram-se precedents para a aceitação dos chamados skilled experts, que poderiam passar a testemunhar como experts, mesmo não tendo títulos, artigos publicados, entre outras qualificações formais.

Após esta introdução, seguem abaixo breves comentários e análises sobre quatro dos principais casos que balizaram e conduziram mudanças na aceitação e entendimento do testemunho das expert witnesses. Tais casos podem ser valiosos para a avaliação do constatado no ordenamento brasileiro e, mais uma vez, contribuir com a discussão acerca dos problemas dos laudos periciais no ordenamento jurídico brasileiro atualmente.

Um dos pioneiros, mas que ao mesmo tempo teve maior longevidade com relação à aceitação dos expert witnesses, foi o caso "Frye v. United States"130, julgado pela Suprema Corte dos Estados Unidos (ou “Supreme Court”) em 1923.

Nesse curioso caso, o réu pleiteou a admissão de levar ao jury, como prova de sua inocência, um teste de pressão (o polígrafo, ou "máquina da mentira"). A Supreme Court denegou o pedido por falta de aceitação geral (ou "general acceptance").

A principal alegação era a de que não havia método científico comprovado ou

${ }^{130}$ Decisão disponível em 〈http://www.daubertontheweb.com/frye opinion.htm>. Acessado em 14 jan. 2013. 
aceito pela comunidade científica no sentido de que a tal "máquina" funcionaria. Portanto, não poderia ela ser aceita, fosse a favor ou contra o réu.

Nesse caso, ficou convencionado que publicações ou técnicas científicas deviam ser preponderantes. Assim, convencionou-se que não se deveriam ser aceitos quaisquer relatos de experts que com a comprovação científica não contassem.

Esse entendimento ficou conhecido por "Frye Test" para a aceitação de "novidades tecnológicas" no processo. Longevo, perdurou no entendimento da Suprema Corte por praticamente 70 anos, ainda que não fosse consensual em todos os Estados.

Um fator curioso sobre o Frye Test é que este, mesmo sem aceitação unânime das cortes Estaduais norte americanas, extrapolou os limites do país, existindo registros de sua menção na fundamentação de diversas decisões ao redor do mundo ${ }^{131}$. Mesmo países com tradição na Civil Law parte da doutrina, durante um bom tempo, defendeu a aplicação desse teste.

Após esse período de "império" do Frye Test, houve três casos, em relativamente curto espaço de tempo, que ficaram conhecidos como a "Trilogia Daubert", e viriam "revolucionar" o entendimento da Supreme Court com relação aos expert witnesses.

O primeiro dessa trilogia, "Daubert v. Merrell Dow Pharmaceuticals", foi julgado em 1991. Tornou-se um marco jurisprudencial que ficou conhecido por "Bendectin cases".

O objeto do processo tratava da má formação de duas crianças, Jason Daubert e Eric Schuller, supostamente por conta do uso do medicamento "Bendectin" no início da gestação, como forma de amenizar enjôos. O medicamento, à época, chegou a ser suspenso, porém anos depois voltou a ser permitido e utilizado ${ }^{133}$.

O trial de Daubert veio "recheado" de perícias e testes (alguns realmente esdrúxulos, e que em nada se relacionavam ao objeto da lide). A "parafernália" que entrou na corte deu origem a muitas críticas, com a derradeira definição do termo junk science. No entanto, esse julgamento transformou-se em um precedent importante de admissibilidade de provas científicas.

${ }^{131}$ CAMPELLO, Lívia Gaigher Bósio. As provas e o recurso à ciência no processo. Disponível em <http://www.ambito-juridico.com.br/site/index.php?n_link=revista_artigos_leitura\&artigo_id=596\#_ftn51 >. Acessado em 02. Jan. 2012

132 Decisão do caso disponível, inclusive com links para outros precedents, em: $<$ http://caselaw.lp.findlaw.com/scripts/getcase.pl?navby=case \&court=us\&vol=509\&page=579>. Acessado em 14 jan. 2013

133 KOLATA, Gina. Controversial Drug Makes a Comeback. Nova Iorque, The New York Times, 2000. Disponível em <http://www.nytimes.com/2000/09/26/science/controversial-drug-makes-acomeback.html?pagewanted=all\&src=pm>. Acessado em 14 jan. 2013 
Nesse caso, a Supreme Court, pela primeira vez, adotou uma postura que contrariou o Frye Test, admitindo meios de provas sem extensa comprovação científica, ou ainda sem que numerosos artigos sobre o assunto tenham sido publicados. Porém, ao mesmo tempo, a postura da Supreme Court indicou haver limites na admissibilidade das provas produzidas pelos experts.

Em Daubert, a corte criou um teste de controle de confiabilidade da prova científica que possui alguns fatores determinantes à admissibilidade. A aprovação em ao menos um dos testes passou a ser fundamental para que provas oriundas de novas tecnologias fossem aceitas.

Tais testes são: i) a falsifiability ("testabilidade" ou confiabilidade) da metodologia utilizada; ii) a publicação prévia de artigos ou livros descrevendo a metodologia; iii) a existência de revisão destas publicações efetivadas por outros cientistas; iv) a determinação precisa da taxa de erro real ou potencial da técnica empregada; v) a manutenção de um padrão de controle durante a aplicação da técnica; e vi) a aceitação geral pela comunidade científica ${ }^{134}$.

Portanto, ao criar regras mais específicas, Daubert quebrou de vez o padrão do Frye Test, aumentando a admissibilidade dessas provas. Porém, dentro de determinados limites; abrindo, assim, caminho para novos precedents.

O segundo precedent dessa trilogia foi o caso "General Electric Co. v. Joiner", julgado pela Supreme Court em $1997^{135}$. O caso envolveu as multinacionais General Electric e Monsanto, além do próprio governo, por conta de uma suposta contaminação pela substância bifenilpoliclorado (ou "PCB", do inglês polychlorinated biphenyl) ${ }^{136}$, que teria causado câncer em Joiner, que por sua vez trabalhava reparando transformadores elétricos que usavam essa substância.

A corte rechaçou diversas possíveis provas a serem levadas por meio dos depoimentos dos experts apontados pelo autor, ora por não reconhecer seus métodos, ora por não guardar relação de nexo causalidade.

O que o caso Joiner trouxe de novo foi a definição pela a Supreme Court de que não apenas a metodologia deveria ser controlada, mas também seu raciocínio, sua lógica para a solução do caso. Como curiosidade, uma das principais críticas da Supreme Court

\footnotetext{
${ }^{134}$ No mesmo sentido: MADURO, Flávio Mirza, op. cit., pp.145-151.

${ }^{135}$ Decisão disponível em 〈http://www.law.cornell.edu/supct/html/96-188.ZS.html〉. Acessado em 14 jan. 2013.

${ }^{136}$ ESTADOS UNIDOS DA AMÉRICA. Environmental Protection Agency. Polychlorinated Biphenyls (PCBs). Disponível em <http://www.epa.gov/osw/hazard/tsd/pcbs/pubs/about.htm>. Acessado em 14 jan. 2013.
} 
nessa discussão foi a respeito de um experimento que comprovou a existência de câncer em camundongos expostos à suposta substância tóxica (PCB), utilizada na refrigeração dos geradores de energia em que trabalhava. O experimento colocou quantidades gigantescas de PCB em camundongos filhotes, e a corte alegou que Joiner "não era camundongo, não era filhote, fora exposto a quantidades muito menores de PCB e, como se não bastasse, fumava"137 (tradução livre).

O terceiro e último dos precedentes "Daubert", foi o caso "Kumho Tire Co. $v$. Carmichael" ${ }^{138}$.O objeto da lide era a suposta responsabilidade da fabricante de pneu por um acidente causado pelo estouro de um pneu de sua fabricação.

Foi a partir desse caso que a jurisprudência da Supreme Court passou a reconhecer os skill experts (conforme acima mencionado). A partir de então ficou consagrada uma nova interpretação da Rule 702 que reconhece como experts não apenas acadêmicos e cientistas, mas também peritos "técnicos" ou "hábeis" ("skilled" em inglês).

Houve, portanto, a partir do caso Carmichael, que encerrou a "revolucionária" trilogia Daubert, o reconhecimento da prova técnica e do perito "hábil”, e não apenas dos peritos "científicos", muito embora tenha se determinado que as provas produzidas pelos skilled experts deveriam ser admitidas sob controles rígidos.

Após esse caso ficou famosa a teoria do "overdeflection" (que equivaleria à separação da borracha ao aço do pneu, com seu consequente estouro), que, segundo a Supreme Court, poderia ser bem explicada por um borracheiro, mas desde que fosse um borracheiro da melhor qualidade e, que entendesse tudo sobre pneus, ainda que não fosse um cientista renomado.

Em suma, os expert witnesses do Direito Norte-americano apresentam diversas diferenças dos peritos, tal como se conhecem no Brasil, e que, no entanto, não permite que se aponte que uma ou outra forma seja melhor, ou mais eficaz, tanto em eficiência quanto em garantismo.

Um ponto que poderia ser aproveitado no ordenamento jurídico brasileiro desses casos e seus exemplos seria a busca de meios para melhor aceitar as revoluções tecnológicas. Obviamente, desde que com parcimônia e segurança, para que não exista um embate entre um "Processo Justo" contra uma "Justiça à toda Prova".

137 BERGER, Margaret A. "What Has a Decade of Daubert Wrought?". In: American Journal of Public Health, Vol. 95, No S1, 2005, pp. 59-65.

138 Decisão do caso disponível, inclusive com links para outros precedents, em: 〈http://caselaw.lp.findlaw.com/scripts/getcase.pl?court=us\&vol=000\&invol=97-1709>. Acessado em 14 jan. 2013. 
No mesmo sentido, fica outro embate exposto entre os dois sistemas, que se faz entre "Oralidade e Celeridade" contra "Legalidade e Contraditório". Ficam como pontos de reflexão se características de um sistema oral e totalmente permissivo encontrariam espaço em um consolidado sistema de Civil Law, como o brasileiro.

Em todos os casos, melhorias advindas de outros sistemas só podem surgir quando confrontadas e, eventualmente, aplicadas. $\mathrm{O}$ que, no caso brasileiro, pode excepcionalmente ocorrer via tribunais superiores e suas súmulas, criando precedents (ou em bom português, precedentes, desejavelmente vinculantes nesse caso), ou ainda por meio de inovações na legislação específica que permitam de forma mais abrangente a utilização das novas ciências e tecnologias na busca da verdade através das provas.

Reitere-se, neste ponto, que o que se pretende cobrar neste estudo nunca foi, e nem poderia ser, que as mais modernas técnicas empregadas nas perícias realizadas em todo o mundo sejam importadas para o Brasil. Ainda que isso fosse desejável. Na verdade, o que se pretende expor e debater é como as formas de admissão de provas e meios de provas podem ser menos engessados; e assim nortearem decisões mais consistentes, embasadas e, de modo empírico, verdadeiras. 


\section{IX - CONCLUSÕES}

i. Preliminarmente, cumpre destacar que ao término das pesquisas notou-se que o presente estudo abordou diversas áreas do conhecimento. Além do Direito e da Medicina, que, obviamente, foram seus focos principais, o enfoque do tema transitou de forma marcante pela História, além de ter tido passagens pela Biologia, Física, Química, entre outras. As conclusões advindas das presentes discussões, embora direcionadas às duas primeiras e principais áreas, podem incentivar avanços nas demais.

Uma vez que todas estas áreas estão umbilicalmente ligadas à perícia médico forense, é quase inconcebível que o avanço em uma delas não interfira nas demais, posto que são transdisciplanares e interdisciplinares. Neste sentido, a história mostra que, embora novidades em apenas uma delas não impactem imediatamente as outras (como é o caso dos avanços nas tecnologias que possibilitam aferições mais aprimoradas), em algum momento as fazem ser repensadas.

A diferença entre os ordenamentos, neste ponto, atualmente é uma questão de celeridade. Afinal, as novas tecnologias são quase imediatamente recepcionadas em alguns ordenamentos jurídicos (como o norte-americano, desde que atendam às exigências dos testes de aceitação). Todavia, demoram demais para serem aplicadas de forma sistemática em outros, como o brasileiro.

ii. Uma segunda conclusão, que despontou no decorrer da pesquisa da parte histórica deste estudo, diz respeito à influência árabe na perícia, e sobremaneira na perícia médico forense. Não poderia pretender este estudo, dada sua linha de pesquisa e seu tema, exaurir as características do Direito Islâmico (que, frise-se, não significa necessariamente Direito Árabe). Mas percebe-se que este, muito além do Corão e da Sunna, tem por fontes básicas o consenso, a analogia, a dedução e a opinião pessoal ${ }^{139}$.

A junção destas fontes, em especial, a dedução visando o consenso, que propiciou provavelmente o melhor ambiente para o desenvolvimento da perícia antes da Era Moderna. Afinal, apenas a partir da influência da escola jurídica Malikita, notadamente através de Averróis, que a Europa continental passou a entender a perícia, e naturalmente a Medicina Legal, como ciência.

Mais ainda, o tratamento diferenciado da perícia no Common Law e no Civil Law

\footnotetext{
${ }^{139}$ KHAN, Ali. "The Second Era of Ijtihad The Reopening of the Islamic Code". In: University of St. Thomas Law Journal, Vol. 1. Topeka, Estados Unidos da América, 2003, p. 341.
} 
também pode ter (ainda que esta idéia não seja consensual entre os estudiosos) explicação, justamente, no Direito Islâmico. Especula-se que não é mera coincidência o fato de existirem tantos pontos em comum entre o Direito Islâmico e o Direito Inglês com relação à forma dos julgamentos e, em especial, a aceitação de evidências, dos meios de prova e, notoriamente, das perícias ${ }^{140}$. Teria havido, segundo preconizam, uma influência deste na formação das bases do ordenamento jurídico inglês e, naturalmente, no Common Law.

Ao adaptar as bases Malikitas da perícia ao Direito da Europa continental, alguns de seus preceitos parecem ter sido deturpados, em virtude da influência da tradição Romana e Germânica nestes ordenamentos. Seria possível inferir que a perícia “original”, portanto, é mais próxima daquela verificada no Common Law do que a dos países que tem tradição no Civil Law. Estes últimos teriam, assim, um instituto "corrompido", que, por vezes, se mostra pouco funcional, conforme descrito reiteradamente na parte de exposição e discussão deste estudo.

iii. As deficiências e carências dos Institutos Médico Legais, atualmente, são inegáveis. Além das reportagens que, recorrentemente, denunciam condições precárias e os próprios dirigentes e chefes de suas divisões reconhecerem o problema, os motivos desta situação parecem bem explicáveis.

Durante os anos da Ditadura Militar, mais que ao Direito e à Justiça, os Institutos Médico Legais serviram ao regime da Ditadura. Nessa fase, obscura, a Medicina Legal esteve sob rígido controle, principalmente nas áreas de Antropologia Forense e Identificação Humana, pois, recorrentemente, não era de interesse do regime ditatorial que ocorresse a determinação da causa mortis bem como a identidade de alguns procurados (ou em melhor acepção, desaparecidos) políticos. Por conta disso, o ensino, a pesquisa e o investimento na área foram afetados durante anos ${ }^{141}$, o que tem reflexos até os dias atuais.

iv. O problema apontado na conclusão anterior é agravado, uma vez que, ainda nos

\footnotetext{
140 DEVICHAND, Mukul. op. cit. Disponível em: <http://news.bbc.co.uk/2/hi/uk_news/magazine/ 7631388.stm>. Acessado em: 02. Jan. 2013.

${ }^{141}$ FRANCISCO, Raffaela Arrabaça. Evolução dos casos de antropologia forense no Centro de Medicina Legal (CEMEL) da Faculdade de Medicina de Ribeirão Preto - USP de 1999 a 2010. Ribeirão Preto, Faculdade de Medicina de Ribeirão Preto, Universidade de São Paulo, 2011, p. 26.
} 
dias atuais, a perícia e os Institutos Médico Legais e os Institutos de Criminalística, quando não estão vinculados à Polícia, estão vinculados à Secretarias de Segurança Pública dos Estados, exceto em três Estados do Brasil (Rio Grande do Sul, Amapá e Pará). Tal fato lhes confere uma aparência que remonta aos tempos da Ditadura, e põe em questionamento sua total isenção.

Ademais, essa estrutura faz com que a perícia concorra em verbas diretamente vinculadas à polícia, uma vez que estão sob a mesma secretaria. Isso tende a corroer ainda mais as poucas verbas destinadas aos Institutos Médico Legais e aos Institutos de Criminalística em ocasiões onde um maior efetivo policial é demandado.

Parece ao autor deste estudo que já tarda a desvinculação dos Institutos Médico Legais das Secretarias de Segurança Pública. Afinal, tal desvinculação em nada parece ter efeitos negativos, e está prevista oficialmente, desde 1996, por ocasião do lançamento do Primeiro Programa Nacional de Direitos Humanos.

v. As iniciativas dos poderes Executivos e Legislativos estaduais tendem a ser escassas e falhas. Um provável motivo desta conclusão, baseada na pesquisa realizada no Estado de São Paulo, é que o anúncio em investimentos no aprimoramento da perícia não capitaliza politicamente, uma vez que a população em geral, vítima de falta de informações, não tem noção da dimensão e da importância que a perícia representa para o Direito penal e para o ordenamento jurídico como um todo.

Por sua vez, o poder Legislativo Federal teria competência apenas para mudar as regras processuais relacionadas à perícia. Em meio a tantas outras discussões de reformas dos códigos travadas recentemente, essa parece ser apenas mais uma, com pouco destaque, até por uma provável falta de conhecimento técnico de boa parte dos operadores do Direito e legisladores. Esse estudo pretende ser uma contribuição a essa discussão, que versa sobre um dos problemas que afetam nossa Justiça criminal, sendo que a questão relacionada às perícias, especificamente, parece trazer prejuízos de forma silenciosa, porém profunda, como poucas outras.

vi. Em decorrência da falta de investimento e interesse político na melhoria da qualidade das perícias, são frequentes laudos imprecisos, não padronizados, e, por vezes, que não acatam os métodos científicos e técnicos mais aceitos. Isso, possivelmente, se dá pela falta de formação adequada das academias de peritos, que não se atualizaram, e também pela ausência de programas de educação continuada para os expertos. 
A solução mais imediata do problema parece, a ao autor desse estudo, ser a formação de parcerias com universidades. Por sua vez, a desvinculação pode ser um facilitador no estabelecimento destes convênios.

vii. Além das propostas mencionadas nos itens anteriores dessa conclusão, outras práticas poderiam ser adotadas como forma de otimizar a qualidade e utilização dos laudos. Um exemplo é a possibilidade de acompanhamento e direcionamento da perícia por um experto indicado pelas partes. Ou, até mesmo, em casos específicos, a realização da perícia por peritos não vinculados ao Estado ou não oficiais, que poderiam ser nomeados ad hoc em casos de maior complexidade.

Tal possibilidade, entretanto, demandaria alterações nos códigos vigentes. E, ao menos até o presente momento, a perícia não parece estar em posição de prestígio na "fila" das emendas mais urgentes.

viii. Com relação à possibilidade de admissão de novas técnicas e meios de prova, o ordenamento jurídico brasileiro poderia adotar regras mais claras e menos restritivas. Nesse sentido, parece a este estudo que o modelo norte-americano, desenvolvedor de um teste de controle de confiabilidade da prova científica para sua admissibilidade, é mais evoluído e saudável ao contraditório; e, se não evita, ao menos inibe a utilização de "ciências de lixo" (ou junk science, conforme conceituado neste estudo).

De forma taxativa, os testes que foram propostos a partir da trilogia Daubert são: i) a falsifiability ("testabilidade" ou confiabilidade) da metodologia utilizada; ii) a publicação prévia de artigos ou livros descrevendo a metodologia; iii) a existência de revisão destas publicações efetivadas por outros cientistas; iv) a determinação precisa da taxa de erro real ou potencial da técnica empregada; v) a manutenção de um padrão de controle durante a aplicação da técnica; e vi) a aceitação geral pela comunidade científica. São, portanto, testes com critérios bem determinados, e possíveis de serem empregados em qualquer ordenamento jurídico.

Parece evidente que a adoção destes critérios poderia contribuir com a evolução da perícia no ordenamento jurídico brasileiro, uma vez que haveria a possibilidade de admissão de laudos de expertos contratados por particulares com maior credibilidade do que nos dias atuais. Ainda que não tivessem paridade de armas na sua relevância, ao menos teriam mais equilíbrio na disputa com os laudos oficiais. 
ix. Parte das possibilidades de evolução destacadas no presente estudo, como a desvinculação dos Institutos Médico Legais e Institutos de Criminalística da Segurança Pública, bem como o aumento das parcerias e convênios com universidades e centros de pesquisas, poderiam ser implementadas imediatamente, sem grandes alterações legislativas ou riscos. Certamente trariam benefícios importantes, ainda que não necessariamente constituíssem soluções definitivas.

Já as inovações mais profundas, em especial aquelas emprestadas de ordenamentos jurídicos estrangeiros, exigem profundos debates para que se possa cogitar as colocá-las em prática. Entretanto, o debate tem que começar em algum ponto. E esse foi o principal objetivo do presente estudo: fomentar a discussão sobre os meios que existem, sejam ou não imediatamente viáveis, para evoluir a perícia como instrumento jurídico do Brasil; conferindo a ela maior credibilidade e precisão; diminuindo, assim, os erros na busca da verdade dos fatos e prevalecendo, desta forma, os preceitos da boa Justiça. 


\section{X - REFERÊNCIAS BIBLIOGRÁFICAS}

ALCÂNTARA, Hermes. Perícia Médico Judicial. $2^{\text {a }}$ ed., Rio de Janeiro, Koogan, 2007.

ALMEIDA, Cândido Mendes de (Org.). Codigo Philippino ou Ordenações e Leis do Reino de Portugal. 14 ed., Rio de Janeiro, Tipografia do Instituto Filomático, 1870. Disponível em: 〈http://www.iuslusitaniae.fcsh.unl.pt/verobra.php?id_obra=65>. Acessado em 28. dez. 2012.

ALMEIDA JUNIOR, João Mendes de. O Processo Criminal Brazileiro, vol. 1, $3^{\text {a }}$ ed., Rio de Janeiro, Livraria Freitas Bastos S.A., 1959.

ALVIM, José Eduardo Carreira. Teoria Geral do Processo. $8^{\mathrm{a}}$ ed, São Paulo, Forense, 2002.

ARANHA, Adalberto José Q. T. Camargo. Da Prova no Processo Penal. $7^{\text {a }}$ Ed. São Paulo, Saraiva, 2006.

ARAUJO, Virginia Procópio de. O ato médico no crime de tortura. São Paulo, Faculdade de Direito da Universidade de São Paulo, 2012.

BENGOCHEA, Jorge Luiz Paz, GUIMARÃES, Luiz Brenner, GOMES, Martin Luiz, ABREU, Sergio Roberto. "A transição de uma Polícia de controle para uma Polícia Cidadã”. In: São Paulo em Perspectiva, São Paulo, Fundação Seade, vol. 18, 2004

BERGER, Margaret A. "What Has a Decade of Daubert Wrought?”. In: American Journal of Public Health, Vol. 95, N S1, 2005

BEZARES Luis E. Rodríguez San Pedro, RODRÍGUEZ, Juan Luis Polo. Universidades Hispánicas: Colegios y Conventos Universitarios en la Edad Moderna. Salamanca, Ediciones Universidad Salamanca, 2009.

BITTAR, Neusa. Medicina Legal. 1 ${ }^{\text {a }}$ ed., Araçatuba, Editora MB, 2009. 
BRASIL, Conselho Federal de Medicina - CFM. Pareceres. Brasília. Disponível em <http://www.portalmedico.org.br>. Acessado em 15 jan. 2013.

. Conselho Federal de Medicina - CFM. Resoluções. Brasília: Disponível em <http://www.portalmedico.org.br>. Acessado em 15 jan. 2013.

, Conselho Regional de Medicina do Estado de São Paulo - CREMESP. Pareceres. São Paulo. Disponível em 〈http://www.cremesp.org.br $>$. Acessado em 15 jan. 2013.

Conselho Regional de Medicina do Estado de São Paulo - CREMESP. Resoluções. São Paulo. Disponível em <http://www.cremesp.org.br $>$. Acessado em 15 jan. 2013.

- Ministério da Justiça. Programa Nacional de Direitos Humanos - 3. Disponível em <http://portal.mj.gov.br/sedh/pndh3/index.html> Acessado em 13 jan. 2013.

CAMPELLO, Lívia Gaigher Bósio. As provas e o recurso à ciência no processo. Disponível em $\quad<$ http://www.ambito-juridico.com.br/site/index.php?n_link=

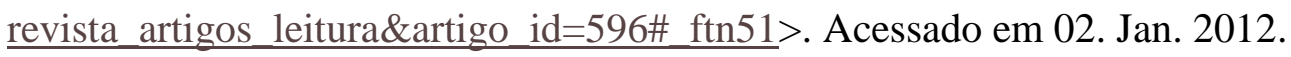

CARVAlHO, H.V. de; SEGRE, M. Compêndio de Medicina Legal. São Paulo, Saraiva, 1987.

CHILE. Codigo de Procedimiento Penal de Chile. Atualizado até a "Ley 19.678". Disponível em <http://www.nuestroabogado.cl/codpropenalsinref.htm>. Acessado em 09 jan. 2013.

CRETELLA JR. José; CINTRA, Geraldo de Ulhoa (Orgs.). Dicionário Latino-Português, $3^{\mathrm{a}}$ ed., São Paulo, Companhia Editora Nacional, 1953. 
DARESTE, Rodolphe. $10^{\mathrm{a}}$ ed., Paris, L. Larose et. L Tenin, 1908. Disponível em $<$ http://ia600306.us.archive.org/23/items/tudesdhistoired00chavgoog/tudesdhistoired00cha vgoog.pdf> Acessado em 28 dez. 2012.

DAVID, René. CARVALHO, Hermínio A. (Trad.). Os grandes sistemas de direito contemporâneo. São Paulo, Martins Fontes, 2001.

DEVICHAND, Mukul. Is English law related to Muslim law?. Londres, 2008. Disponível em: <http://news.bbc.co.uk/2/hi/uk_news/magazine/7631388.stm>. Acessado em: 02. Jan. 2013.

DESCARTES, René. JUNIOR, Bento Prado (Trad.). “Descartes”. In: Os pensadores. Vol. XV. São Paulo, Abril Cultural, 1973.

DEZEM, Guilherme Madeira. Da prova penal: tipo processual, provas típicas e atípicas. Campinas, Millenium, 2008.

DINAMARCO, Cândido Rangel. A Instrumentalidade do Processo. $6^{\mathrm{a}}$ ed. São Paulo, Malheiros, 1998.

ELLIS, Peter Barresford. The Celtic Empire. Durham, Estados Unidos da América, Carolina Academic Press, 1990.

ESPANHA Ley de Enjuciamiento Criminal. Disponível em 〈http://www.fmyv.es/ci/es/Ss/11.pdf $>$. Acessado em 09 jan. 2013.

ESTADOS UNIDOS DA AMÉRICA. Federal Rules of Criminal Procedure. Atualizado até $01 \mathrm{dez}$. 2012. Disponível em: 〈http://www.law.cornell.edu/rules/frcrmp >. Acessado em 14 jan. 2013

Federal Rules of Criminal Procedure. Atualizado até 01 dez. 2012. Disponível em: 〈http://www.law.cornell.edu/rules/fre/>. Acessado em 14 jan. 2013. 
FERNANDES, Antonio Scarance. "Provas e sucedâneos da prova no processo penal”. In: Revista Brasileira de Ciências Criminais. São Paulo, RT, jun. 2007.

FERNANDES, Antonio Scarance; ALMEIDA, José Raul Gavião de; MORAES, Mauricio Zanóide de (Coord.). Provas no Processo Penal - Estudo Comparado. São Paulo, Saraiva, 2011.

FERRAJOLI, Luigi. Garantismo: debate sobre el derecho y la democracia. Madrid: Trotta, 2006.

FOLHA DA MANHÃ S.A.. IMLs de SP têm instalações precárias, cheiro podre e falta de técnicos. 2013. Disponível em <http://www1.folha.uol.com.br/cotidiano/1210727-imls-desp-tem-instalacoes-precarias-cheiro-podre-e-falta-de-tecnicos.shtml>. Acessado em 06 jan. 2013.

. Comissão da Verdade toma depoimento de legista da ditadura. 2013.

Disponível em <http://www1.folha.uol.com.br/fsp/poder/50258-comissao-da-verdadetoma-depoimento-de-legista-da-ditadura.shtml>. Acessado em 16 jan. 2013.

FRANÇA, Genival Veloso de. Medicina Legal. $9^{\text {a }}$ Ed. Rio de Janeiro, Guanabara Koogan, 2012.

FRANCISCO, Raffaela Arrabaça. Evolução dos casos de antropologia forense no Centro de Medicina Legal (CEMEL) da Faculdade de Medicina de Ribeirão Preto - USP de 1999 a 2010. Ribeirão Preto, Faculdade de Medicina de Ribeirão Preto, Universidade de São Paulo, 2011.

GIBBON, Edward; SAUDERS, Dero A. (Org,); PAES, José Paulo (Trad.). Declínio e queda do Império Romano. Ed. abr. São Paulo, Companhia da Letras, 2005.

GONZAGA, João Bernardino. A inquisição em seu mundo. São Paulo, Saraiva, 1993.

GOVERNO DO ESTADO DE SÃO PAULO. Secretaria de Segurança Pública. Resolução SSP-05/2013. São Paulo, Diário Oficial - Poder Executivo, 08 jan. 2013. 
. Secretaria de Segurança Pública. Unidades do Instituto Médico Legal. São Paulo, 2013.

. Secretaria de Segurança Pública. Histórico do Instituto Médico Legal. São Paulo, 2013.

- Secretaria de Segurança Pública. Descritivo funcional do Instituto Médico Legal. São Paulo, 2013.

. Lei Complementar $n^{\circ}$ 1064, de 13 de novembro de 2008. São Paulo, Diário Oficial - Poder Executivo, 14 nov. 2008.

GRIGULEVICH, Iosif Romualdovitch. KUZNETSOV, M. (Trad.). Historia de la Inquisición. Moscou, Editora Progresso, 1980.

GRINOVER, Ada Pellegrini. A instrução processual penal na América Latina: culturas e sistemas jurídicos comparados. Cidade do México, Universidad Autonoma de Mexico, 2004.

GRINOVER, Ada Pellegrini; SCARANCE FERNANDES, Antonio; GOMES FILHO, Antonio Magalhães. As nulidades no processo penal. $8^{\mathrm{a}}$ ed, São Paulo, Revista dos Tribunais, 2004

GROS, G. M. “A primeira história andaluza das ciências”. In: CARDAILLAC, L. (Org.). Toledo, século XII-XIII: muçulmanos, cristãos e judeus: o saber e a tolerância. Rio de Janeiro: Zahar, 1992.

HABERMAS, Jürgen. Era das transições. Rio de Janeiro, Tempo Brasileiro, 2003.

HÉRCULES, Hygino. Medicina Legal: Texto e Atlas. Rio de Janeiro, Atheneu, 2005.

HOBSBAWN, Eric J; PENCHEL, Marcos (Trad.) Era das Revoluções - 1789 -1848. 25 Ed., São Paulo, Paz e Terra, 2009. 
HOUAISS, Antonio. Grande Dicionário Houaiss da Língua Portuguesa. Disponível em <http://houaiss.uol.com.br>. Acesso em: 23 dez. 2012.

ITÁLIA. Codice de Procedura Penale. Disponível em <http://dbase.ipzs.it/cgifree/db2www/notai/arti.mac/SOMMARIO?datagu=10/24/1988\&redaz=088G0492\&swpag $\underline{=12 \mathrm{~B}}>$. Acessado em 13 jan. 2013.

- Museo Criminologico. Cesare Lombroso the Inventor of Criminal Anthropology. Disponível em 〈http://www.museocriminologico.it/lombroso_1_uk.htm>. Acessado em 02 jan. 2013.

JOHNS, Claude Hermann Walters (Org.). Enyclopaedia Britanica. 11 ${ }^{\mathrm{a}}$ ed. Londres, Enyclopaedia Britanica, Inc., 1901.

KHAN, Ali. "The Second Era of Ijtihad The Reopening of the Islamic Code". In: University of St. Thomas Law Journal, Vol. 1. Topeka, Estados Unidos da América, 2003.

KOBS, Günther; POLAINO NAVARRETE, Miguel; POLAINO-ORTS, Miguel. Bien jurídico, vigencia de la norma y daño social. Lima, Ara, 2010.

KOLATA, Gina. Controversial Drug Makes a Comeback. Nova Iorque, The New York Times, 2000. Disponível em <http://www.nytimes.com/2000/09/26/science/controversial-

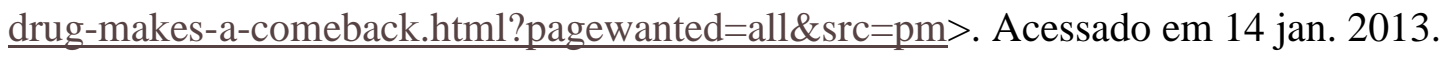

LAGO, Cristiano Alves Valladares. Sistemas Processuais Penais. Disponível em 〈http://www.viannajr.edu.br/revista/dir/doc/art_30005.pdf>, p. 05. Acessado em 15. Dez. 2012.

MADURO, Flávio Mirza. Prova Pericia: Em busca de um novo paradigma. Rio de Janeiro, Faculdade Gama Filho, 2007.

MAJZOUB, Milene Chavez Goffar. Juízos de Deus e Justiça Real no Direito Carolíngio. Campinas, Universidade Estadual de Campinas, 2005. 
MARQUES, José Frederico. FERRARI, Eduardo Reali, DEZEM, Guilherme Madeira (Atual.). Elementos do Direito Processual Penal. Vol. 2, $3^{\text {a }}$ Ed. Campinas, Millenium, 2009.

MARTINS, Adilton Luís. "Pensar as Origens". In: História: Questões \& Debates, n. 48/49, Curitiba, Editora UFPR, 2008.

MOREIRA, José Carlos Barbosa. In: "Notas sobre alguns aspectos do processo (civil e penal) nos países anglo- saxônicos”. In: Temas de Direito Processual. $7^{\text {a }}$ série. São Paulo, Saraiva, 2001

MORERA, Darío Fernandez. "The mith of Andalusian Paradise". In: The Intercollegiate Review, Wilmington, Estados Unidos da América, ISI, outono 2006.

NASCIMENTO JUNIOR, Antonio Fernandes. "Fragmentos da história das concepções de mundo na construção das ciências da natureza: das certezas medievais às dúvidas prémodernas". In: Ciência \& Educação, v.9, n. 2. Bauru, Unesp, 2003.

OLIVEIRA, R. A.. "Ética médica e bioética. Saúde”. In: Ética \& Justiça, v. (1/2):, p. 26-8, 2005.

. “A evolução científica e tecnológica e a ética do medico" (editorial). In: Jornal Vascular Brasileiro, v. 5(1), p. 1-2, 2006.

OLIVEROS, Raúl Tavolari. Instituiciones del nuevo processo penal. Cuetiones y casos. Santiago, Editorial Juridica del Chile, 2006.

PILLADO, Esther González; CANLE, Inés Iglecias. "La prueba pericial en la nueva ley de enjuiciamento civil”. In: Revista Xurídica Galega. № 27, Vigo, Rexurga, 2000.

PORTUGAL. Assembleia da República. Código de Processo Penal Português. Disponível em <http://www.portolegal.com/CPPen.htm> . Acessado em 13 jan. 2013. 
PREFEITURA DA CIDADE DE SÃO PAULO. Programa de Aprimoramento das Informações de Mortalidade. 1989 a 2013. Conteúdo disponível em <http://www.prefeitura.sp.gov.br/cidade/secretarias/saude/epidemiologia_e_informacao/m ortalidade/>. Acessado em: 02 jan. 2013.

PSYCHIATRIC, A.A.. PEREIRA, Daniel de Menezes (Trad.). Princípios Éticos da Associação de Psiquiatria Americana. São Paulo, CREMESP, 2006.

REALE JÚNIOR, Miguel. "Caminhos do direito penal brasileiro". In: Revista Brasileira de Ciências Criminais, São Paulo, v. 18, n. 85, p.41-76, jul./ago. 2010.

ROSEN, George. Da polícia médica à medicina social. Rio de Janeiro: Graal, 1979.

ROXIN, Claus. Estudos de direito penal. Rio de Janeiro, Renovar, 2006.

ROXIN, Claus. CÓRDOBA, Gabriela E.; PASTOR, Daniel R (Trad.). Derecho Procesal Penal. Buenos Aires, Editores del Puerto, 2000

SÁ, Alvino Augusto de; SHECAIRA, Sérgio Salomão. Criminologia e os problemas da atualidade. São Paulo, Atlas, 2008.

SANTIAGO, Rodrigo. "Sobre a prova pericial no Código de Processo Penal de 1987”. In: Revista Portuguesa de Ciência Criminal. Coimbra, Ed. Coimbra, 2001.

SALDANHA, Nelson Nogueira. A Lei das doze tábuas e o direito penal romano. Revista Symposium, Recife, v. 3, n. 1/2, 1961.

SANTOS, Moacyr Amaral. Prova Judiciária no cível e comercial, vol. 1, $5^{\mathrm{a}}$ ed. atual., vol. 1, São Paulo, Saraiva, 1983.

SILVA, Alexandre Alberto Gonçalves. A perícia forense no Brasil.São Paulo, Escola Politécnica da Universidade de São Paulo, 2010.

STADEN, Hans. Duas viagens ao Brasil. São Paulo, L\&M Pocket, 2008. 
TOURINHO FILHO, Fernando da Costa. Processo Penal, v. 1, 32 ed., São Paulo, Saraiva, 2010.

TUCCI, Rogério Lauria. Curso de Direito Processual Penal. São Paulo, Saraiva, 2004.

TUCCI, José Rogério Cruz e; AZEVEDO, Luiz Carlos de. Lições de História do Processo Civil Romano, São Paulo, Revista dos Tribunais, 2001.

WELCH, G.; SCHWARTZ, L.; WOLOSHIN, S.. PEREIRA, Daniel de Menezes (Trad.). “O que está nos deixando doentes é uma... epidemia de diagnósticos”. In Jornal do Cremesp. São Paulo, CREMESP, 2008.

WORRAL, John L.; HEMMENS, Craig. Criminal Evidence: an introduction. Los Angeles, Roxbury Publishing Company, 2005.

ZACHARIAS, M. \& ZACHARIAS, E. Dicionário de Medicina Legal, Curitiba: Educa, 1988.

ZAFFARONI, Eugenio Raúl. "Desafios do direito penal na era da globalização". In: Cidadania e Justiça, Rio de Janeiro, v. 2, n. 5, p.200-204, 1998. 